\title{
ATTEMPTS TO MONOPOLIZE AND NO-FAULT MONOPOLIZATION
}

\section{Milton Handler $†$ and Ruchard M. Steuer $\dagger$}

The National Commission for the Review of Antitrust Laws and Procedures was convened by Executive Order ${ }^{1}$ in June, 1978 to study means for expediting complex antitrust litigation and improving the effectiveness of antitrust remedies. ${ }^{2}$ It devoted an entire chapter of its final report to proposals for revising the substantive law on monopolization, ${ }^{3}$ asserting that confused legal standards in this area "are an important contributing factor to unnecessary delay and ineffective remedies in antitrust litigation." 4 The Commission considered two principal modifications of current law: revision of the "attempt to monopolize" offense and adoption of the concept of "no-conduct" or "no-fault" monopolization. Specifically, the Commission recommended (1) the modification of the "dangerous probability of success" requirement in the offense of attempted monopolization; ${ }^{5}$ and (2) that a congressional inquiry be undertaken to determine the feasibility of eliminating the "willful acquisition or maintenance" requirement from the offense of monopolization itself. ${ }^{\boldsymbol{B}}$

\section{Attempts to Monopolize}

It is generally recognized that to establish the offense of attempted monopolization ${ }^{7}$ under present standards a plaintiff must prove three elements: (1) specific intent to monopolize; (2) conduct

† Professor Emeritus of Law, Columbia University. A.B. 1924, LL.B. 1926, Columbia University; LL.D. (honoris causa) 1965, Hebrew University. Member, New York Bar.

t† B.A. 1970, Hofstra University; J.D. 1973, Columbia University. Member, New York Bar.

Grateful acknowledgment is made to John P. Colangelo for his valuable assistance in the preparation of this article.

1 Exec. Order No. 12,022, 3 C.F.R. $\$ 155$ (1977), as amended by Exec. Order No. 12,052, 43 Fed. Reg. 15,133 (1978).

2 National Commisston for the Review of Antmtaust Laws and Procedures, Report to the Presment and the Attorney General 320, 323 (1979) [hereinafter cited as REPORT].

3 Id. 141-74.

4 Id. $143-44$.

51d. 150-51.

6 Id. 151-52, 162.

7 "Every person who shall monopolize, or attempt to monopolize, . . . any part of the trade or commerce among the several States, or with foreign nations, shall be deemed guilty of a felony...." Sherman Act, 15 U.S.C. $\$ 2$ (1976). 
designed to implement that intent; and (3) a dangerous probability of success. ${ }^{8}$ The Commission recommended that the third requirement-that plaintiff prove a "dangerous probability of success"be changed to a requirement that plaintiff prove a "dangerous risk of monopoly." " The report contains the text of a "Proposed Competition Protection Act" which would add the following proviso to section 2 of the Sherman Act:

Provided that, in determining whether a person has attempted to monopolize a part of trade or commerce, (1) a dangerous risk of monopoly shall be held to exist upon a showing that the conduct alleged to constitute the attempt significantly threatens competition in any relevant market, as determined after an evaluation of the defendant's intent, the defendant's present or probable market power, and the anticompetitive potential of the conduct undertaken. . . . 10

According to the Commission, the current requirement that a dangerous probability of success be proved in order to establish attempted monopolization "poses serious problems for effective antitrust enforcement" 11 because "under the prevailing view, close proximity to monopoly, in the form of a near-monopoly market share, and a high probability of actual monopolization are often considered prerequisites to a finding of dangerous probability." 12 The expressed intent behind substituting "dangerous risk" for "dangerous probability" was "to avoid the implication" that there must be proof of "a greater than 50 percent chance that monopoly will occur." 13

The Commission pointed to the Eighth Circuit's decision in United States v. Empire Gas Corp.,14 as a "troubling illustration" of the dangerous probability requirement being used to excuse clearly anticompetitive single-firm behavior from liability. ${ }^{15} \mathrm{Re}$ -

8 See text accompanying notes 23-30 infra. Proof of a fourth element, antitrust injury, is, of course, also required in the attempted monopolization context.

9 Within its discussion of attempts to monopolize, the Commission also made specific recommendations concerning the definition of predatory pricing. REPORT, supra note 2, at 149-50. This proposal will not be analyzed in this Article and will be addressed only as it applies to the recommendation concerning dangerous probability. See text accompanying notes 64-66 infra.

10 RePort, supra note 2 , at 166 (emphasis omitted).

11 Id. 144.

12 Id. 146.

$131 d .151$ (footnote omitted).

14537 F.2d 296 (8th Cir. 1976), cert. denied, 429 U.S. 1122 (1977).

15 RePORT, supra note 2 , at 146. 
lying on the Seventh Gircuit's opinion in Kearney \& Trecker Corp. v. Giddings \& Lewis, Inc., ${ }^{16}$ the Commission advocated a "balancing approach" in assessing legality, under which the dangerous probability element would be retained not as a requirement, but only to "shed light" on a defendant's intent and "to limit the offense to cases in which the potential anticompetitive impact of the defendant's conduct is truly significant." 17 The Commission would adopt a sliding scale under which the importance of the dangerous probability factor would vary in inverse proportion to the perniciousness of the conduct under scrutiny. Traditional proof of dangerous probability of success through proof of market power would be relatively important where defendant's conduct is "competitively ambiguous," but would become less important where such conduct is "unambiguously anticompetitive." 18 In the latter case, the Commission would accept proof of the conduct itself as sufficient evidence of a dangerous probability of success, with little or no market analysis.

The Commission saw two benefits resulting from its approach. First, the reach of section 2 could be extended to "unambiguously anticompetitive behavior," hitherto allegedly protected by a strict dangerous probability requirement. Second, delays purportedly arising from the present need to engage in lengthy market analysis and definition, even when conduct "inherently destructive of competition" is involved, would be eliminated.

Appraisal of the merits of the Commission's approach and the validity of its underlying assumptions requires the examination of both in the context of existing law. Accordingly, in the sections that follow, we will summarize the development and scope of the current standards before discussing the Commission's proposal for change.

\section{A. The Present State of the Law}

To the Commission, the present law of attempted monopolization is uneven, unclear, inconsistent and conflicting-the adjectives are its own. ${ }^{19}$ The Commission charged that business behavior that is lawful in one jurisdiction is unlawful in another. ${ }^{20}$ Con-

16452 F.2d 579, 598 (7th Cir. 1971), cert. denied, 405 U.S. 1066 (1972).

17 RePORT, supra note 2, at 146.

18 Id. 148.

19 Report, supta note 2 , at $144,165$.

20 Id. 165. 
duct that is clearly and significantly anticompetitive-or in the words of one witness "plainly predatory or vicious" 21 -assertedly goes unpunished because courts apply the current standards of illegality too strictly. ${ }^{22}$

In determining whether the Commission's indictment of current law is well founded, it is appropriate to begin with the Supreme Court's decision in Swift \& Co. v. United States, ${ }^{23}$ in which Justice Holmes first outlined the essential elements of the attempt to monopolize offense:

Intent . . . is essential to such an attempt. Where acts are not sufficient in themselves to produce a result which the law seeks to prevent-for instance, the monopoly-but require-further acts in addition to the mere forces of nature to bring that result to pass, an intent to bring it to pass is necessary in order to produce a dangerous probability that it will happen. . . . But when that intent and the consequent dangerous probability exist, [section 2] ... directs itself against that dangerous probability as well as against the completed result. ${ }^{24}$

Later in the opinion, Justice Holmes made clear that under this formulation "dangerous probability" is not simply an inevitable consequence of intent: "Not every act that may be done with intent to produce an unlawful result is unlawful, or constitutes an attempt. It is a question of proximity and degree. The distinction between mere preparation and attempt is well known in the criminal law." 25

The Holmes requirement of a dangerous probability of success has sometimes evaked criticism, ${ }^{26}$ but contrary to the Commission's

21 Id. 145 \& 168 n.12 (citing testimony of Donald I. Baker).

22 Id. $145-46$.

23196 U.S. 375 (1905).

24 Id. 398 (citation omitted).

25 Id. 402 (citation omitted). See Varney v. Coleman Co., 385 F. Supp. 1337, 1343 (D.N.H. 1974); Hibner, Attempts to Monopolize: A Concept in Search of Analysis, 34 ANTITRUst L.J. 165, 174-75 (1967); Kintner \& Goldston, Section 2 of the Sherman Act: The Attempt to Monopolize Offense, 24 N.Y.L. ScE. L. Rev. 577,583 (1979).

26 See, e.g., Blecher, Attempt to Monopolize Under Section 2 of the Sherman Act: "Dangerous Probability" of Monopolization Within the "Relevant Market," 38 Geo. WASE. L. Rev. 215 (1969); Turner, Antitrust Policy and the Cellophane Case, 70 Harv. L. Rsv. 281, 304-07 (1956); Turner, The Scope of "Attempt to Monopolize," 30 Rec. A.B. Crry N.Y. 487, 503-04 (1975); Note, Prosecutions for Attempts to Monopolize: The Relevance of the Relevant Market, 42 N.Y.U. L. REv. 110, 117-20 (1967); Note, Attempt to Monopolize: The Offense Redefined, 1969 UTAH. L. REv. 704, 713-18. 
suggestion, ${ }^{27}$ the Supreme Court ${ }^{28}$ and every circuit but the Ninth ${ }^{20}$ has consistently and uniformly adhered to it. ${ }^{30}$ These courts have limited liability to instances in which a single actor was engaged in improper conduct with the specific intent to obtain a monopoly, and came close enough to realize this goal in a correctly defined market to warrant the conclusion that there had been a dangerous probability of success. The Commission's report leaves one with the impression that there has been a sharp cleavage in the courts as to the wisdom of retaining the Holmes approach and that the case law is in a state of irreconciliable conflict. In reality, the federal courts have been virtually unanimous in their acceptance of the Holmes rubric.

\section{Grounds for Decision}

Most plaintiffs lose attempted monopolization suits not because they fail to prove a dangerous probability of monopoly but because (1) they fail to prove specific intent; (2) the defendant's alleged conduct is not truly anticompetitive; (3) the market is incorrectly defined; or (4) the percentage of the market controlled by the defendant is too low to create any colorable risk of monopoly. Since 1905 there have been some 200 reported actions charging defendants with an attempt to monopolize. Of these, roughly one

27 REPORT, supra note 2, at 144.

28 In American Tobacco Co. v. United States, 328 U.S. 781, 785 (1946), the Supreme Court approved a jury instruction defining attempted monopolization as "the employment of methods, means and practices which would, if successful, accomplish monopolization, and which, though falling short, nevertheless approach so close as to create a dangerous probability of it."

20 See text accompanying notes 105-48 infra.

30 E.g., First Circuit: George R. Whitten, Jr., Inc. v. Paddock Pool Builders, Inc., 508 F.2d 547 (Ist Cir. 1974), cert. denied, 421 U.S. 1004 (1975); Second Circuit: Nifty Foods Corp. v. Great Atl. \& Pac. Tea Co., 614 F.2d 832 (2d Cir. 1980); Third Circuit: Coleman Motor Co. v. Chrysler Corp., 525 F.2d 1338, 1348 n.17 (3d Cir. 1975); Rea v. Ford Motor Co., 497 F.2d 577, 590 n.28 (3d Cir. 1974), cert. denied, 419 U.S. 868 (1975); Fourth Circuit: White Bag Co. v. International Paper Co., 579 F.2d 1384 (4th Cir. 1974); Fifth Circuit: Cliff Food Stores, Inc. v. Kroger, Inc., 417 F.2d 203 (5th Cir. 1969); Sixth Circuit: Volasco Prods. Co. v. Lloyd A. Fry Roofing Co., 308 F.2d 383, 390 (6th Cir. 1962), cert. denied, 372 U.S. 907 (1963); Seventh Circuit: Mullis v. Arco Petr. Corp., 502 F.2d 290 (7th Cir. 1974); Eighth Circuit: United States v. Empire Gas Corp., 537 F.2d 296 (8th Cir. 1976), cert. denied, 429.U.S. 1122 (1977); Hiland Dairy, Inc. v. Kroger Co., 402 F.2d 968 (8th Cir. 1968), cert. denied, 395 U.S. 961 (1969); Tenth Circuit: E. J. Delaney Corp. v. Bonne Belle, Inc., 525 F.2d 296 (10th Cir. 1975), cert. denied, 425 U.S. 907 (1976); District of Columbia Circuit: Oetiker v. Jurid Werke, G.m.b.H., 556 F.2d 1 (D.C. Cir. 1977); Merit Motors, Inc. v. Chrysler Corp., 417 F. Supp. 263 (D.D.C. 1976), affd on other grounds, 569 F.2d 666 (D.C. Cir. 1977). 
quarter were decided in favor of the plaintiff on the attempt claim; ${ }^{31}$

31 Less than half of these decisions ordered judgment for plaintiffs, however; the remainder were preliminary decisions: United States Supreme Court: Lorain Journal Co. v. United States, 342 U.S. 143 (1951) (judgment for plaintiff after bench trial affirmed); Swift \& Co. v. United States, 196 U.S. 375 (1905) (defendant's motion to dismiss denied); Second Circuit: Northeastern Tel. Co. v. American Tel. \& Tel. Co., 1980-I Trade Cas. I 63,593 (D. Conn. 1980) (defendant's motion for judgment n.o.v. denied); Flair Zipper Corp. v. Textron, Inc., 1980-2 Trade Cas. โ 63,294 (S.D.N.Y. 1980) (summary judgment for defendant denied); Jennings Oil Co. v. Mobil Oil Corp., 1979-2 Trade Cas. If 62,826 (S.D.N.Y. 1979) (denial of defendant's motion for judgment on the pleadings); Brager \& Co. v. Leumi Secs. Corp., 429 F. Supp. 1341 (S.D.N.Y. 1977) (defendant's motion to dismiss denied); Third Circuit: Columbia Metal Culvert Co. v. Kaiser Alum. \& Chem. Corp., 579 F.2d 20 (3d Cir.) (directed verdict for defendants reversed), cert. denied, 439 U.S. 876 (1978); Knuth v. Erie-Crawford Dairy Coop. Ass'n, 395 F.2d 420 (3d Cir. 1968) (grant of defendant's motion to dismiss reversed), cert. denied, 410 U.S. 913 (1973); Outboard Marine Corp. v. Pezetel, 461 F. Supp. 384 (D. Del. 1978) (defendant's motion to dismiss denied); W. L. Gore \& Assoc. v. Carlisle Corp., 381 F. Supp. 680 (D. Del. 1974) (judgment for defendant on counterclaim), aff'd in part and rev'd in part on other grounds, 529 F.2d 614 (3d Cir. 1976); United States v. Firestone Tire \& Rubber Co., 374 F. Supp. 431 (N.D. Ohio 1974) (plaintiff's motion to strike defendant's affirmative defense granted); Power Replacements Corp v. Air Preheater Co., 356 F. Supp. 872 (E.D. Pa. 1973) (judgment for plaintiff after bench trial); Mt. Lebanon Motors, Inc. v. Chrysler Corp., 283 F. Supp. 453 (W.D. Pa. 1968) (defendant's motion for directed verdict denied), aff'd per curiam, 417 F.2d 622 (3d Cir. 1969); United States v. Jerrold Elecs. Corp., 187 F. Supp. 545 (E.D. Pa. 1960) (judgment for plaintiff after bench trial), aff'd per curiam, 365 U.S. 567 (1961); Fourth Circuit: Greenville Publ. Co. v. Daily Reflector, Inc., 496 F.2d 391 (4th Cir. 1974) (summary judgment for defendant reversed); Ray v. United Family Life Ins. Co., 430 F. Supp. 1353 (W.D.N.C. 1977) (defendant's motion for summary judgment denied); Bowl Am., Inc. v. Fair Lanes, Inc., 299 F. Supp. 1080 (D. Md. 1969) (judgment for plaintiffs after bench trial); Campbell Distrib. Co. v. Jos. Schlitz Brewing Co., 208 F. Supp. 523 (D. Md. 1962) (defendant's motion for summary judgment denied); Fifth Circuit: Associated Radio Service Co. v. Page Airways, Inc., 624 F.2d 1342 (5th Cir. 1980) (judgment for plaintiff after jury trial affirmed); United States v. Dunham Concrete Prods., Inc., 501 F.2d 80 (5th Cir. 1974) (judgment for plaintiff after jury trial affirmed), cert. denied, 421 U.S. 930 (1975); Six Twenty-Nine Prods., Inc. v. Rollins Telecasting, Inc., 365 F.2d 478 (5th Cir. 1966) (summary judgment for defendant reversed); North Tex. Producers Ass'n v. Metzger Dairies, Inc., 348 F.2d 189 (5th Cir. 1965) (judgment for plaintiff after jury trial affirmed), cert. denied, 382 U.S. 977 (1966); Joe Westbrook, Inc. v. Chrysler Corp., 419 F. Supp. 824 (N.D. Ga. 1976) (defendant's motion for summary judgment denied); Credit Bureau Reports, Inc. v. Retail Credit Co., 358 F. Supp. 780 (S.D. Tex. 1971) (judgment for plaintiff after bench trial affirmed), aff'd, 476 F.2d 989 (5th Cir. 1973); Sixth Circuit: Kearney \& Trecker Corp. v. Cincinnati Milacron, Inc., 562 F.2d 365 (6th Cir. 1977) (judgment for plaintiff after bench trial affirmed); Alles Corp. v. Senco Prods., Inc., 329 F.2d 567 (6th Cir. 1964) (grant of defendant's motion to dismiss reversed); Seventh Circuit: Kearney \& Trecker Corp. v. Giddings \& Lewis, Inc., 452 F.2d 579 (7th Cir. 1971) (dismissal of defendant's counterclaim reversed), cert. denied, 405 U.S. 1066 (1972); Photovest Corp. v. Fotomat Corp., 1977-1 Trade Cas. T 61,529 (S.D. Ind. 1977), aff'd in part, rev'd in part, remanded, 606 F.2d 704 (7th Cir. 1979) (judgment for plaintiffs after bench trial affirmed), cert. denied, 100 S. Ct. 1278 (1980); Lektro-Vend Corp. v. Vendo Co., 403 F. Supp. 527 (N.D. IIl. 1975) (plaintiff's motion for preliminary injunction granted), aff', 545 F.2d 1050 (7th Cir. 1976), rev'd on other grounds, 433 U.S. 623 (1977); Smith-Victor Corp. v. Sylvania Elec. Prods., Inc., 242 F. Supp. 302 (N.D. Ill. 1965) (defendant's motion for summary judgment denied); Eighth Circuit: Morning Pioneer, Inc. v. Bismarck Tribune Co., 493 F.2d 383 (8th Cir.) (judgment for plaintiff after 
bench trial affirmed), cert. denied, 419 U.S. 836 (1974); TV Signal Co. v. American Tel. \& Tel. Co., 462 F.2d 1256 (8th Cir. 1972) (grant of defendant's motion to dismiss reversed); Sanitary Milk Producers v. Bergjans Farm Dairy, Inc., 368 F.2d 679 (8th Cir. 1966) (jury verdict for plaintiff affirmed); Kansas City Star Co. v. United States, 240 F.2d 643 (8th Cir.) (jury verdict for plaintiff affirmed), cert. denied, 354 U.S. 923 (1957); American Standard, Inc. v. Bendix Corp., 487 F. Supp. 265 (W.D. Mo. 1980) (defendant's motion for summary judgment denied); Fox Chem. Co. v. Amsoil, Inc., 445 F. Supp. 1355 (D. Minn. 1978) (defendant's motion for summary judgment denied); Clausen \& Sons v. Theo. Hamm Brewing Co., 284 F. Supp. 148 (D. Minn. 1967) (defendant's motion for summary judgment denied), rev'd on other grounds, 395 F.2d 388 ( 8 th Cir. 1968); United States v. Klearflax Linen Looms, Inc., 63 F. Supp. 32 (D. Minn. 1945) (judgment for plaintiff after bench trial); Ninth Circuit: Hunt-Wesson Foods, Inc. v. Ragu Foods, Inc., 627 F.2d 919 (9th Cir. 1980) (grant of defendant's motion to dismiss reversed); Ernest W. Hahn, Inc. v. Codding, 615 F.2d 830 (9th Cir. 1980) (dismissal of defendant's counterclaim reversed); Sherman v. British Leyland Motors, Ltd., 601 F.2d 429 (9th Cir. 1979) (summary judgment for defendant reversed); Purex v. Procter \& Gamble Co., 596 F.2d 881 (9th Cir. 1979) (judgment for defendants after bench trial reversed); Greyhound Computer Corp. v. IBM, 559 F.2d 488 (9th Cir. 1977) (directed verdict for defendant reversed), cert. denied, 434 U.S. 1040 (1978); Pacific Coast Agr. Export Ass'n v. Sunkist Growers, Inc., 526 F.2d 1196 (9th Cir. 1975) (judgment for plaintiff after jury trial affirmed), cert. denied, 425 U.S. 959 (1976); Moore v. Jas. H. Matthews \& Co., 473 F.2d 328 (9th Cir. 1973) (summary judgment for defendant reversed); Industrial Bldg. Materials, Inc. v. Interchemical Corp., 437 F.2d 1336 (9th Cir. 1970) (summary judgment for defendant reversed); Case-Swayne Co. v. Sunkist Growers, Inc., 369 F.2d 449 (9th Cir. 1966) (directed verdict for defendant reversed), rev'd on other grounds, 389 U.S. 384 (1967); Jerrold Elecs. Corp. v. Wescoast Broadcasting Co., 341 F.2d 653 (9th Cir.) (jury verdict for plaintiff affirmed), cert. denied, 382 U.S. 817 (1965); Lessig v. Tidewater Oil Co., 327 F.2d 459 (9th Cir.) (jury verdict for defendants reversed), cert. denied, 377 U.S. 993 (1964); Naify v. McClatchy Newspapers, 1977-1 Trade Cas. \61,383 (N.D. Cal. 1977) (defendant's motion for summary judgment denied); Foremost Int'l Tours, Inc. v. Qantas Airways, Ltd., 379 F. Supp. 88 (D. Hawaii 1974) (defendant's motion for summary judgment denied), aff'd, 525 F.2d 281 (9th Cir. 1975), cert. denied, 429 U.S. 816 (1976); Jack Winter, Inc. v. Koratron Co., 375 F. Supp. 1 (N.D. Cal. 1974) (judgment for plaintiff after bench trial); Dobbins v. Kawasaki Motors Corp., 362 F. Supp. 54 (D. Or. 1973) (defendant's motion for summary judgment denied); Tenth Circuit: Perington Wholesale, Inc. v. Burger King Corp., 1979-2 Trade Cas. If 62,986 (10th Cir. 1979) (grant of defendant's motion to dismiss reversed in part); District of Columbia Circuit: Oetiker v. Jurid Werke, G.m.b.H., 556 F.2d I (D.C. Cir. 1977) (grant of defendant's motion to dismiss reversed).

A number of cases in which plaintiffs have prevailed involved so-called "leveraging" of established monopoly power in one market to obtain a competitive advantage in a second market. While these efforts have sometimes been viewed as attempts to monopolize the second market-with suggestions that proof of a dangerous probability of success should be dispensed with because monopoly power exists in the first market-the better analysis is to treat these situations as the exercise of the monopoly power defendant already possesses in the first market and thus as acts of monopoly rather than attempted monopoly. This approach is suggested by Berkey Photo, Inc. v. Eastman Kodak Co., 603 F.2d 263 (2d Cir. 1979), cert. denied, $100 \mathrm{~S}$. Ct. 1061 (1980), which held that "the use of monopoly power attained in one market to gain a competitive advantage in another is a violation of $\S 2$, even if there has not been an attempt to monopolize the second market." 603 F.2d at 276. The court explained: "Since monopoly power itself is the target of $\$ 2$, it is unreasonable to suggest that a firm that possesses such power in one market and uses it to damage competition in another does not 'monopolize' within the meaning of the statute." Id. 276 n.15. Thus, violation of section 2 can be proved in a leveraging case without establishing either a specific intent to monopolize the second market or a dangerous probability of success. This renders such cases of limited utility in understanding the law of attempted monopolization, although 


\section{the remainder were decided in favor of the defendant. ${ }^{32}$ In light}

some courts have looked to attempted monopolization precedents in explaining their decisions. The leveraging cases include Otter Tail Power Co. v. United States, 410 U.S. 366 (1973); United States v. Griffith, 334 U.S. 100 (1948); Eastman Kodak Co. v. Southern Photo Materials Co., 273 U.S. 359 (1927); Sargent-Welch Scientific Co. v. Ventron Corp., 567 F.2d 701 (7th Cir. 1977), cert. denied, 439 U.S. 822 (1978); City of Mishawaka v. American Elec. Power Co., 465 F. Supp. 1320 (W.D. Ind. 1979), affd, 616 F.2d 976 (7th Cir. 1980).

32 United States Supreme Court: Times-Picayune Publ. Co. v. United States, 345 U.S. 594 (1953); United States v. Columbia Steel Co., 334 U.S. 495 (1948); First Circuit: George R. Whitten, Jr., Inc. v. Paddock Pool Bldrs., Inc., 508 F.2d 547 (Ist Cir. 1974), cert. denied, 421 U.S. 1004 (1975); Walker v. Providence Journal Co., 493 F.2d 82 (1st Cir. 1974); Transitron Elec. Corp. v. Hughes Aircraft Co., 487 F. Supp. 885 (D. Mass. 1980); Dankese Eng'r, Inc. v. Ionics, Inc., 469 F. Supp. 149 (D. Mass. 1979); Vogue Ring Creations, Inc. v. Hardman, 410 F. Supp. 609 (D.R.I. 1976); Varney v. Coleman Co., 385 F. Supp. 1337 (D.N.H. 1974); Union Leader Corp. v. Newspapers of New England, Inc., 180 F. Supp. 125 (D. Mass.), modified, 284 F.2d 582 (1st Cir. 1960), cert. denied, 365 U.S. 833 (1961); Second Circuit: Nifty Foods Corp. v. Great Atl. \& Pac. Tea Co., 614 F.2d 832 (2d Cir. 1980); Buffalo Courier-Express, Inc. v. Buffalo Evening News, Inc., 601 F.2d 48 (2d Cir. 1979); CBS, Inc. v. American Soc. of Composers, Authors Publishers, 562 F.2d 130 (2d Cir. 1977), rev'd on other grounds and remanded sub nom. Broadcast Music Inc. v. CBS, Inc.., 441 U.S. I (1979); FL.M Collision Parts, Inc. v. Ford Motor Co., 543 F.2d 1019 (2d Cir. 1976), cert. denied, 429 U.S. 1097 (1977); Kreager v. General Elec. Co., 497 F.2d 468 (2d Cir. 1974), cert. denied, 419 U.S. 861 (1975); United States v. Consolidated Laundries Corp., 291 F.2d 563 (2d Cir. 1961); Syracuse Broadcasting Corp. v. Newhouse, 236 F.2d 522 (2d Cir. 1956); Flair Zipper Corp. v. Textron Inc., 1980-2 Trade Cas. If 63,555 (S.D.N.Y. 1980); Levitch v. CBS, Inc., 495 F. Supp. 649 (S.D.N.Y. 1980); McDaniel v. General Motors Corp., 480 F. Supp. 666 (E.D.N.Y. 1979); Speed Auto Sales, Inc. v. American Motors Corp., 477 F. Supp. 1193 (E.D.N.Y. 1979); Paralegal Inst., Inc. v. American Bar Ass'n, 1980-1 Trade Cas. I63,096 (E.D.N.Y. 1979); Air Freight Haulage Co. v. Ryd-Air, Inc., 1978-2 Trade Cas. I 62,321 (S.D.N.Y. 1978). affd mem., 603 F.2d 211 (2d Cir.), cert. denied, 100 S. Ct. 134 (1979); Fuchs Sugars \& Syrups, Inc. v. Amstar Corp., 447 F. Supp. 867 (S.D.N.Y. 1978), rev'd on other grounds, 602 F.2d 1025 (2d Cir.), cert. denied, 444 U.S. 864 (1979); American Bd. of Trade v. American Stock Exch., 430 F. Supp. 655 (S. D. N.Y. 1977); Giant Paper \& Film Corp. v. Albemarle Paper Co., 430 F. Supp. 981 (S.D.N.Y. 1977); Unibrand Tire \& Prod. Co. v. Armstrong Rubber Co., 429 F. Supp. 470 (W.D.N.Y. 1977); Diehl \& Sons v. International Harvester Co., 426 F. Supp. 110 (E.D.N.Y. 1976); United States v. Airco, Inc., 386 F. Supp. 915 (S.D.N.Y. 1974); Bowen v. New York News, Inc., 366 F. Supp. 651 (S.D.N.Y. 1973), aff'd in part and rev'd in part, 522 F.2d 1242 (2d Cir. 1975), cert. denied, 425 U.S. 936 (1976); GAF Corp. v. Circle Floor Co., 329 F. Supp. 823 (S.D.N.Y. 1971), aff'd, 463 F.2d 752 (2d Cir. 1972), cent. dismissed, 413 U.S. 901 (1973); SCM Corp. v. Radio Corp. of Am., 318 F. Supp. 433 (S.D.N.Y. 1970); Sam S. Goldstein Indus., Inc. v. Botany Indus., Inc., 301 F. Supp. 728 (S.D.N.Y. 1969); United States v. Chas. Pfizer \& Co., 245 F. Supp. 737 (E.D.N.Y. 1965); United States v. Singer Mfg. Co., 205 F. Supp. 394 (S.D.N.Y. 1962), rev'd on other grounds, 374 U.S. 174 (1963); Bender v. Hearst Corp., 152 F. Supp. 569 (D. Conn. 1957), affd, 263 F.2d 360 (2d Cir. 1959); Third Circuit: Edward J. Sweeney \& Sons v. Texaco, Inc., 1980-1 Trade Cas. If 63,61l (3d Cir. 1980); Harold Friedman, Inc. v. Kroger Co., 581 F.2d 1068 (3d Cir. 1978); Coleman Motor Co. v. Chrysler Corp., 525 F.2d 1338 (3d Cir. 1975); Rea v. Ford Motor Co., 497 F.2d 577 (3d Cir. 1974), cert. denied. 419 U.S. 868 (1975); Gold Fuel Serv., Inc. v. Esso Standard Oil Co., 306 F.2d 61 (3d Cir. 1962), cert. denied, 371 U.S. 951 (1963); Structure Probe Inc. v. Franklin Inst., 450 F. Supp. 1272 (E.D. Pa. 1978); Webber v. Wynne, 431 F. Supp. 1048 (D.N.J. 1977); Carlo C. Gelardi Corp. v. Miller Brewing Co., 421 F. Supp. 237 (D.N.J. 1976); Mogul v. General Motors 
Corp., 391 F. Supp. 1305 (E.D. Pa. 1975), affd, 527 F.2d 645 (3d Cir. 1976); Keco Indus., Inc. v. Borg-Warner Corp., 334 F. Supp. 1240 (M.D. Pa. 1971); N.W. Controls, Inc. v. Outboard Marine Corp., 333 F. Supp. 493 (D. Del. 1971); Fourth Circuit: White Bag Co. v. International Paper Co., 579 F.2d 1384 (4th Cir. 1974); Advance Bus. Sys. \& Supply Co. v. SCM Corp., 415 F.2d 55 (4th Cir. 1969), cert. denied, 397 U.S. 920 (1970); McElhenney Co. v. Western Auto Supply Co., 269 F.2d 332 (4th Cir. 1959); Nelligan v. Ford Motor Co., 262 F.2d 556 (4th Cir. 1959); Human Resources Inst. of Norfolk, Inc. v. Blue Cross, 484 F. Supp. 520, 529 n.5 (E.D. Va. 1980); Neugebauer v. A.S. Abell Co., 474 F. Supp. 1053 (D. Md. 1979); Diamond Int'l Corp. v. Walterhoefer, 289 F. Supp. 550 (D. Md. 1968); American Football League v. National Football League, 205 F. Supp. 60 (D. Md. 1962), affd, 323 F.2d 124 (4th Cir. 1963); Fifth Circuit: Spectrofuge Corp. v. Beckman Instrs., Inc., 575 F.2d 256 (5th Cir. 1978), cert. denied, 440 U.S. 939 (1979); Pinder v. Hudgins Fish Co., 570 F.2d 1209 (5th Cir. 1978); International Tel. \& Tel. Corp. v. United Tel. Co., 550 F.2d 287 (5th Cir. 1977); Yoder Bros. v. California-Florida Plant Corp., 537 F.2d 1347 (5th Cir.), cert. denied, 429 U.S. 1094 (1976); Sulmeyer v. Coca Cola Co., 515 F.2d 835 (5th Cir.), cert. denied, 424 U.S. 934 (1975); Scranton Constr. Co. v. Litton Indus. Leasing Corp., 494 F.2d 778 (5th Cir. 1974); cert. denied, 419 U.S. 1105 (1975); Panotex Pipe Line Co. v. Phillips Petroleum Co., 457 F.2d 1279 (5th Cir.), cert. denied, 409 U.S. 845 (1972); Cliff Food Stores, Inc. v. Kroger, Inc., 417 F.2d 203 (5th Cir. 1969); Bowmar Instr. Corp. v. Texas Instrs., Inc., No. 74-137 (S.D. Tex., filed March 30, 1978); Alabama v. Blue Bird Body Co., 71 F.R.D. 606 (M.D. Ala. 1976), aff'd in part and rev'd in part on other grounds, 573 F.2d 309 (5th Cir. 1978); Southern Concrete Co. v. United States Steel Corp., 394 F. Supp. 362 (N.D. Ga. 1975), aff'd on other grounds, 535 F.2d 313 (5th Cir. 1976), cert. denied, 429 U.S. 1096 (1977); Coca Cola Co. v. Howard Johnson Co., 386 F. Supp. 330 (N.D. Ga. 1974); Southeastern Hose, Inc. v. Imperial-Eastman Corp., 1973-1 Trade Cas. 『74,479 (N.D. Ga. 1973); Cal Distrib. Co. v. Bay Distribs., Inc., 337 F. Supp. 1154 (M.D. Fla. 1971); Kershaw v. Kershaw Mfg. Co., 209 F. Supp. 447 (M.D. Ala. 1962), aff'd per curiam, 327 F.2d 1002 (5th Cir. 1964); Sixth Circuit: Raceway Properties, Inc. v. Emprise Corp., 613 F.2d 656 (6th Cir. 1980); Daily Press, Inc. v. United Press Int'l, 412 F.2d I26 (6th Cir.), cert. denied, 396 U.S. 990 (1969); Southern Blowpipe \& Roofing Co. v. Chattanooga Gas Co., 360 F.2d 79 (6th Cir. 1966), cert. denied, 393 U.S. 844 (1968); Ace Beer Distribs., Inc. v. Kohn, Inc., 318 F.2d 283 (6th Cir.), cert. denied, 375 U.S. 922 (1963); Volasco Prods. Co. v. Lloyd A. Fry Roofing Co., 308 F.2d 383 (6th Cir. 1962), cert. denied, 372 U.S. 907 (1963); International Visible Sys. Corp. v. Remington-Rand, Inc., 65 F.2d 540 (6th Cir. 1933); Pennwalt Corp. v. Zenith Labs., Inc., 472 F. Supp. 413 (E.D. Mich. 1979); Copperstone v. Griswold Sporting Goods Co., 1977-2 Trade Cas. 161,623 (E.D. Mich. 1977); Oak Distrib. Co. v. Miller Brewing Co., 370 F. Supp. 889 (E.D. Mich. 1973); Zenith Vinyl Fabric Corp. v. Ford Motor Corp., 357 F. Supp. 133 (E.D. Mich. 1973), aff'd, No. 73-1537 (6th Cir., filed June 6, 1974) ("not for publication"), cert. denied, 419 U.S. 967 (1974); Huron Valley Publ. Co. v. Booth Newspapers, Inc., 336 F. Supp. 659 (E.D. Mich. 1972); Allen Ready Mix Concrete Co. v. John A. Denie's Sons Co., 1972 Trade Cas. I 73,955 (W.D. Tenn. 1972); B \& B Oil \& Chem. Co. v. Franklin Oil Corp., 293 F. Supp. 1313 (E.D. Mich. 1968); Seventh Circuit: Chillicothe Sand \& Gravel Co. v. Martin Marietta Corp., 615 F.2d 427 (7th Cir. 1980); Sargent-Welch Scientific Co. v. Ventron Corp., 567 F.2d 701 (7th Cir. 1977), cert. denied, 439 U.S. 822 (1978); Mullis v. Arco Petroleum Co., 502 F.2d 290 (7th Cir. 1974); Bendix Corp. v. Balax, Inc., 471 F.2d 149 (7th Cir. 1972), cert. denied, 414 U.S. 819 (1973); La Salle St. Press, Inc. v. McCormick \& Henderson, Inc., 445 F.2d 84 (7th Cir. 1971); Bernard Food Indus., Inc. v. Dietene Co., 415 F.2d 1279 (7th Cir. 1969), cert. denied, 397 U.S. 912 (1970); Mackey v. Sears, Roebuck \& Co., 237 F.2d 869 (7th Cir. 1956); Lektro-Vend Corp. v. Vendo Corp., 1980-2 Trade Cas. If 63,444 (N.D. Ill. 1980); Tapeswitch Corp. of Am. v. Recora Co., 1977-2 Trade Cas. T 61,584 (N.D. Ill. 1977); Tire Sales Corp. v. Cities Serv. Oil Co., 410 F. Supp. 1222 (N.D. Ill. 1976); C.A.R. Leasing, Inc. v. First Lease, Inc., 394 F. Supp. 306 (N.D. Ill. 1975); Pecora Oil Co. v. Shell Oil Co., 1975-1 Trade Cas. I 60,156 (N.D. Ill. 1975); Radzik v. Chicagoland Rec. Vehicle Dealers Ass'n, 1972 Trade Cas. $\llbracket 74,167$ 
(N.D. Ill. 1972); Brewer Sewing Supplies, Co. v. Fritz Gegauf, Ltd., 1970 Trade Cas. I 73,139 (N.D. Ill. 1970); South End Oil Co. v. Texaco, Inc., 237 F. Supp. 650 (N.D. III. 1965); Eighth Circuit: Duckworth v. EMI Medical, Inc., 1980-2 Trade Cas. T63,386 (8th Cir. 1980); United States v. Empire Gas Corp., 537 F.2d 296 (8th Cir. 1976), cert. denied, 429 U.S. 1122 (1977); Morton Bldgs. of Neb., Inc. v. Morton Bldgs., Inc., 531 F.2d 910 (8th Cir. 1976); Acme Precision Prods., Inc. v. American Alloys Corp., 484 F.2d 1237 (8th Cir. 1973); Agrashell, Inc. v. Hammons Prods. Co., 479 F.2d 269 (8th Cir.), cert. denied, 414 U.S. 1022 (1973); Central Savs. \& Loan Ass'n v. Federal Home Loan Bank Bd., 422 F.2d 504 (8th Cir. 1970); Hiland Dairy, Inc. v. Kroger Co., 402 F.2d 968 (8th Cir. 1968), cert. denied, 395 U.S. 961 (1969); Stifel, Nicolaus \& Co. v. Dain, Kalman \& Quail, Inc., 430 F. Supp. 1234 (N.D. Iowa 1977); McCormack v. Theo. Hamm Brewing Co., 284 F. Supp. 158 (D. Minn. 1968); Ninth Circuit: Carpet Seaming Tape Licensing Corp. v. Best Steam Inc., 616 F.2d 1133 (9th Cir. 1980); Cowley v. Braden Indus., Inc., 613 F.2d 751 (9th Cir. 1980); Blair Foods, Inc. v. Ranchers Cotton Oil, 610 F.2d 665 (9th Cir. 1980); California Computer Prods., Inc. v. IBM, 613 F.2d 727 (9th Cir. 1979); Naify v. McClatchy Newspapers, 599 F.2d 335 (9th Cir. 1979); Gough v. Rossmoor Corp., 585 F.2d 381 (9th Cir. 1978), cert. denied, 440 U.S. 936 (1979); Marquis v. Chrysler Corp., 577 F.2d 624 (9th Cir. 1978); Janich Bros. v. American Distilling Co., 570 F.2d 848 (9th Cir. 1977), cert. denied, 439 U.S. 829 (1978); Brown v. Hansen Publs. Inc., 556 F.2d 969 (9th Cir. 1977); Mutual Fund Investors, Inc. v. Putnam Mgt. Co., 553 F.2d 620 (9th Cir. 1977); Moore v. Jas. H. Matthews \& Co., 550 F.2d 1207 (9th Cir. 1977); Knutson v. Daily Review Inc., 548 F.2d 795 (9th Cir. 1976), cert. denied, 433 U.S. 910 (1977); Hanson v. Shell Oil Co., 541 F.2d 1352 (9th Cir. 1976), cert. denied, 429 U.S. 1074 (1977); Twin City Sportservice, Inc. v. Charles O. Finley \& Co., 512 F.2d 1264 (9th Cir. 1975); ALW, Inc. v. United Air Lines, Inc., 510 F.2d 52 (9th Cir. 1975); Trixler Brokerage Co. v. Ralston Purina Co, 505 F.2d 1045 (9th Cir. 1974); Chisholm Bros. Farm Equip. Co. v. International Harvester Co., 498 F.2d II37 (9th Cir.), cert. denied, 419 U.S. 1023 (1974); Hallmark Indus. v. Reynolds Metals Co., 489 F.2d 8 (9th Cir. 1973), cert. denied, 417 U.S. 932 (1974); Bushie v. Stenocord Corp., 460 F.2d 116 (9th Cir. 1972); Dahl, Inc. v. Roy Cooper Co., 448 F.2d 17 (9th Cir. 1971); Cornwell Quality Tools Co. v. C.T.S. Co., 446 F.2d 825 (9th Cir. 1971), cert. denied, 404 U.S. 1049 (1972); Walker Distrib. Co. v. Lucky Lager Brewing Co., 323 F.2d 1 (9th Cir. 1963), cert. denied, 385 U.S. 976 (1966); Independent Iron Works, Inc. v. United States Steel Corp., 322 F.2d 656 (9th Cir.), cert. denied, 375 U.S. 922 (1963); Scott Publ. Co. v. Columbia Basin Publs., Inc., 293 F.2d 15 (9th Cir.), cert. denied, 368 U.S. 940 (1961); General Business Sys. v. North Am. Philips Corp., 1980-1 Trade Cas. f 63,607 (N.D. Cal. 1980); Fast Food Fabricators v. McDonald's Corp., 1980-2 Trade Cas. If 63,552 (N.D. Cal. 1980); Filmamatic Corp. v. General Electric Co., 1980-2 Trade Cas. ( 63,417 (N.D. Cal. 1980); Roberts Waikiki U-Drive, Inc. v. Budget Rent-A-Car Systems, Inc., 491 F. Supp. 1199 (D. Hawaii 1980); Determined Prods., Inc. v. R. Dakin \& Co., 1980-1 Trade Cas. I 63,063 (N.D. Cal. 1979); Pure Water Resources, Inc. v. Consolidated Foods Corp., 1980-1 Trade Cas. T 63,064 (N.D. Cal. 1979); In re Western Asphalt Cases, 478 F. Supp. 785 (N.D. Cal. 1979); Foremost Int'l Tours, Inc. v. Qantas Airways, Ltd., 478 F. Supp. 589 (D. Hawaii 1979); California Steel \& Tube v. Kaiser Steel Corp., 469 F. Supp. 265 (C.D. Cal. 1979); Murphy Tugboat Co. v. Crowley, 467 F. Supp. 841 (N.D. Cal. 1978); William Inglis \& Sons Baking Co. v. ITT Cont. Baking Co., 461 F. Supp. 410 (N.D. Cal. 1978); Zoslaw v. CBS, Inc., 1978-2 Trade Cas. If 62,269 (N.D. Cal. 1978); General Comm's Eng'r, Inc. v. Motorola Comm's \& Elec., Inc., 421 F. Supp. 274 (N.D. Cal. 1976); Wisdom Rubber Indus. v. Johns-Manville Sales Corp., 415 F. Supp. 363 (D. Hawaii 1976); Tenth Circuit: Perington Wholesale, Inc. v. Burger King Corp., 1979-2 Trade Cas. I 62,986 (10th Cir. 1979) (grant of defendant's motion to dismiss affirmed in part); Pacific Eng'r \& Prod. Co. v. Kerr-McGee Corp., 551 F.2d 790 (10th Cir. 1977); E.J. Delaney Corp. v. Bonne Belle, Inc., 525 F.2d 296 (10th Cir. 1975), cert. denied, 425 U.S. 907 (1976); Telex Corp. v. IBM, 510 F.2d 894 (10th Cir.), cert. dismissed, 423 U.S. 802 (1975); Bank of Utah v. Commercial Sec. Bank, 369 F.2d 19 (10th Cir. 1966), cert. denied, 386 U.S. 1018 (1967); H.F.\&S. Co. v. American Std., Inc., 336 F. Supp. 110 (D. Kan. 1968); 
of the Commission's claim that the dangerous probability requirement has caused undue delay in attempt litigation, it is significant that half of the cases were decided summarily and never tried.

Decisions in almost half of the cases in which the defendant prevailed were based on a failure of proof of intent to monopolize. ${ }^{33}$

Becker v. Safelite Glass Corp., 244 F. Supp. 625 (D. Kan. 1965); District of Columbia Circuit: Filmdex Chex Sys. Inc. v. Telecheck Wash. Inc., 1979-2 Trade Cas. If 62,976 (D.D.C. 1979); Merit Motors, Inc. v. Chrysler Corp., 417 F. Supp. 263 (D.D.C. 1976), aff'd on other grounds, 569 F.2d 666 (D.C. Cir. 1977).

33 United States Supreme Court: Times-Picayune Publ. Co. v. United States, 345 U.S. 594 (1953); United States v. Columbia Steel Co., 334 U.S. 495 (1948); First Circuit: George R. Whitten, Jr., Inc. v. Paddock Pool Bldrs., Inc., 508 F.2d 547 (1st Cir. 1974), cert. denied, 421 U.S. 1004 (1975); Union Leader Corp. v. Newspapers of New England, Inc., 284 F.2d 582 (Ist Cir. 1960), cert. denied, 365 U.S. 833 (196I); Dankese Eng'r, Inc. v. Ionics, Inc., 469 F. Supp. 149 (D. Mass. 1979); Vogue Ring Creations, Inc. v. Hardman, 410 F. Supp. 609 (D.R.I. 1976); Second Circuit: Buffalo Courier-Express, Inc. v. Buffalo Evening News, Inc., 601 F.2d 48 (2d Cir. 1979); FLM Collision Parts, Inc. v. Ford Motor Co., 543 F.2d 1019 (2d Cir. 1976), cert. denied, 429 U.S. 1097 (1977); Bowen v. New York News, Inc., 366 F. Supp. 651 (S.D.N.Y. 1973), affd in part and rev'd in part, 522 F.2d 1242 (2d Cir. 1975), cert. denied, 425 U.S. 936 (1976); Kreager v. General Elec. Co., 497 F.2d 468 (2d Cir.), cert. denied, 419 U.S. 861 (1974); GAF Corp. v. Circle Floor Co., 329 F. Supp. 823 (S.D.N.Y. 1971), aff'd, 463 F.2d 752 (2d Cir. 1972), cert. dismissed, 413 U.S. 901 (1973); Flair Zipper Corp. v. Textron, Inc., 1980-2 Trade Cas. đ 63,555 (S.D.N.Y. 1980); Paralegal Inst., Inc. v. American Bar Ass'n, 1980-1 Trade Cas. โ 63,096 (E.D.N.Y. 1980); Air Freight Haulage Co. v. Ryd-Air, Inc., 1978-2 Trade Cas. I63,321 (S.D.N.Y. 1978), affd mem., 603 F.2d 211 (2d Cir.), cert. denied, 444 U.S. 917 (1979); American Bd. of Trade v. American Stock Exch. 430 F. Supp. 655 (S.D.N.Y. 1977); United States v. Airco, Inc., 386 F. Supp. 915 (S.D.N.Y. 1974); Sam. S. Goldstein Indus., Inc. v. Botany Indus., Inc., 301 F. Supp. 728 (S.D.N.Y. 1969); United States v. Singer Mfg. Co., 205 F. Supp. 394 (S.D.N.Y. 1962), rev'd on other grounds, 374 U.S. 174 (1963); Bender v. Hearst Corp., 152 F. Supp. 569 (D. Conn. 1957), affd, 263 F.2d 360 (2d Cir. 1959); Third Circuit: Harold Friedman, Inc. v. Kroger Co., 581 F.2d 1068 (3d Cir. I978); Gold Fuel Serv., Inc. v. Esso Standard Oil Co., 306 F.2d 61 (3d Cir. 1962), cert. denied, 371 U.S. 951 (1963); Structure Probe Inc. v. Franklin Inst., 450 F. Supp. 1272 (E.D. Pa. 1978); Webber v. Wynne, 431 F. Supp. 1048 (D.N.J. 1977); Keco Indus., Inc. v. Borg-Warner Corp., 334 F. Supp. 1240 (M.D. Pa. 1971); N.W. Controls, Inc. v. Outboard Marine Corp., 333 F. Supp. 493 (D. Del. 1971); Fourth Circuit: White Bag Co. v. International Paper Co., 579 F.2d 1384 (4th Cir. 1974); McElhenney Co. v. Western Auto Supply Co., 269 F.2d 332 (4th Cir. 1959); Human Resources Inst. of Norfolk, Inc. v. Blue Cross, 484 F. Supp. 520, 529 n.5 (E.D. Va. 1980); American Football League v. National Football League, 205 F. Supp. 60 (D. Md. 1962), aff d, 323 F.2d 124 (4th Cir. 1963); Fifth Circuit: International Tel. \& Tel. Corp. v. United Tel. Co., 550 F.2d 287 (5th Cir. 1977); Panotex Pipe Line Co. v. Phillips Petroleum Co., 457 F.2d 1279 (5th Cir.), cert. denied, 409 U.S. 845 (1972); Alabama v. Blue Bird Body Co., 71 F.R.D. 606 (M.D. Ala. 1976), affd in part and rev'd in part on other grounds, 573 F.2d 309 (5th Cir. 1978); Southern Concrete Co. v. United States Steel Corp., 394 F. Supp. 362 (N.D. Ga. 1975), aff'd on other grounds, 535 F.2d 313 (5th Cir. 1976), cert. denied, 429 U.S. 1096 (1977); Credit Bureau Reports, Inc. v. Retail Credit Co., 358 F. Supp. 780 (S.D. Tex. 197I), affd, 476 F.2d 989 (5th Cir. 1973); Kershaw v. Kershaw Mfg. Co., 209 F. Supp. 447 (M.D. Ala. 1962), aff'd per curiam, 327 F.2d 1002 (5th Cir. 1964); Sixth Circuit: Daily Press, Inc. v. United Press Int'l, 412 F.2d 126 (6th Cir. 1969), cert. denied, 396 U.S. 990 (1969); International Visible Sys. Corp. v. Remington-Rand, Inc., 65 F.2d 540 (6th Cir. 1933); Huron Valley Publ. Co. v. Booth Newspapers, Inc., 336 F. Supp. 659 (E.D. Mich. 1972); Seventh Circuit: Sargent-Welch Scientific Co. v. Ventron 
Intent has long been the most elusive element of the attempt offense, the distinction between an intent to compete successfully and an intent to injure competition often being difficult to discern. Yet the distinction must be drawn, ${ }^{84}$ and no one, including the Commission,

Corp., 567 F.2d 701 (7th Cir. 1977), cert. denied, 439 U.S. 822 (1978); Bernard Food Indus., Inc. v. Dietene Co., 415 F.2d 1279 (7th Cir. 1969), cert. denied, 397 U.S. 912 (1970); Mackey v. Sears, Roebuck \& Co., 237 F.2d 869 (7th Cir. 1956); C.A.R. Leasing, Inc. v. First Lease, Inc., 394 F. Supp. 306 (N.D. IIl. 1975); Pecora Oil Co. v. Shell Oil Co., 1975-1 Trade Cas. $\int 60,156$ (N.D. Ill. 1975); Eighth Circuit: Morton Bldgs. of Neb., Inc. v. Morton Bldgs., Inc., 531 F.2d 910 (8th Cir. 1976); Central Savs. \& Loan Ass'n v. Federal Home Loan Bank Bd., 422 F.2d 504 (8th Cir. 1970); Hiland Dairy, Inc. v. Kroger Co., 402 F.2d 968 (8th Cir. 1968), cert. denied, 395 U.S. 961 (1969); Stifel, Nicolaus \& Co. v. Dain, Kalman \& Quail, Inc., 430 F. Supp. 1234 (N.D. Iowa 1977); Ninth Circuit: Blair Foods, Inc. v. Ranchers Cotton Oil, 610 F.2d 665 (9th Cir. 1980); Naify v. McClatchy Newspapers, 599 F.2d 335 (9th Cir. 1979); Gough v. Rossmoor Corp., 585 F.2d 381 (9th Cir. 1978), cert. denied, 440 U.S. 936 (1979); Janich Bros. v. American Distilling Co., 570 F.2d 848 (9th Cir. 1977), cert. denied, 439 U.S. 829 (1978); Brown v. Hansen Publs., Inc., 556 F.2d 969 (9th Cir. 1977); Mutual Fund Investors, Inc. v. Putnam Mgt. Co., 553 F.2d 620 (9th Cir. 1977); Moore v. Jas. H. Matthews \& Co., 550 F.2d 1207 (9th Cir. 1977); Knutson v. Daily Review, Inc., 548 F.2d 795 (9th Cir. 1976), cert. denied, 433 U.S. 910 (1977); Hanson v. Shell Oil Co., 541 F.2d 1352 (9th Cir. 1976), cert. denied, 429 U.S. 1074 (1977); Twin City Sportservice, Inc. v. Charles O. Finley \& Co., 512 F.2d 1264 (9th Cir. 1975); ALW, Inc. v. United Air Lines, Inc., 510 F.2d 52 (9th Cir. 1975); Trixler Brokerage Co. v. Ralston Purina Co., 505 F.2d 1045 (9th Cir. 1974); Chisholm Bros. Farm Equip. v. International Harvester Co., 498 F.2d 1137 (9th Cir.), cert. denied, 419 U.S. 1023 (1974); Hallmark Indus. v. Reynolds Metals Co., 489 F.2d 8 (9th Cir. 1973), cert. denied, 417 U.S. 932 (1974); Bushie v. Stenocord Corp., 460 F.2d 116 (9th Cir. 1972); Cornwell Quality Tools Co. v. C.T.S. Co., 446 F.2d 825 (9th Cir. 1971), cert. denied, 404 U.S. 1049 (1972); Walker Distrib. Co. v. Lucky Lager Brewing Co., 323 F.2d 1 (9th Cir. 1963); Independent Iron Works, Inc. v. United States Steel Corp., 322 F.2d 656 (9th Cir.), cert. denied, 375 U.S. 922 (1963); Scott Publ. Co. v. Columbia Basin Publs., Inc., 293 F.2d 15 (9th Cir.), cert. denied, 368 U.S. 940 (1961); Fast Food Fabricators v. McDonald's Corp., 1980-2 Trade Cas. I 63,552 (N.D. Cal. 1980); Pure Water Resources, Inc. v. Consolidated Foods Corp., 1980-I Trade Cas. \63,064 (N.D. Cal. 1979); California Steel \& Tube v. Kaiser Steel Corp., 469 F. Supp. 265 (C.D. Cal. 1979); Zoslaw v. CBS, Inc., 1978-2 Trade Cas. I 62,629 (N.D. Cal. 1978); General Comm's Eng'r, Inc. v. Motorola Comm's \& Elecs., Inc., 421 F. Supp. 274 (N.D. Cal. 1976); Tenth Circuit: Bank of Utah v. Commercial Sec. Bank, 369 F.2d 19 (10th Cir. 1966), cert. denied, 386 U.S. 1018 (1967); District of Columbia Circuit: Filmdex Chex Sys., Inc. v. Telecheck Wash., Inc., 1979-2 Trade Cas. I 62,976 (D.D.C. 1979); Merit Motors, Inc. v. Chrysler Corp., 417 F. Supp. 263 (D.D.C. 1976), affd, 569 F.2d 666 (D.C. Cir. 1977). Because some plaintiffs fail for lack of proof on more than one of the essential elements of the attempt to monopolize offense, the categorization of decisions in this and the following notes necessitates counting several cases in more than one category.

34 See, e.g., Buffalo Courier-Express, Inc. v. Buffalo Evening News, Inc., 601 F.2d 48 (2d Cir. 1979), in which the plaintiff argued that the new owner of a Buffalo newspaper demonstrated an intent to destroy his only competitor and achieve a monopoly by offering subscribers seven free issues of a newly introduced Sunday edition. Vacating a preliminary injunction, Judge Friendly observed:

[W]e find simply no evidence that Mr. Buffett acquired the News with the idea of putting the Courier out of business as distinguished from providing vigorous competition, including the invasion of what had been the Courier's exclusive Sunday market. . . . All that the record supports is a finding that Mr. Buffett intended to do as well as he could with the 
has advocated abandoning the requirement of proving an improper intent. ${ }^{35}$

Despite the Commission's ambivalent attitude toward past judicial handling of the intent issue, ${ }^{36}$ its vague recommendation that evidence of defendants' conduct is "preferable" to extrinsic evidence of intent, and should be sufficient to prove specific intent, ${ }^{37}$ will do little to affect treatment of the intent issue. The Commission's proposed legislation merely restates existing judicial practice regarding intent. ${ }^{38}$

Only forty-one of the collected cases decided in favor of defendants have turned on conduct, the courts finding that plaintiffs failed to prove the anticompetitive behavior that they had alleged. ${ }^{39}$

Id. 54 .

News and was not lying awake thinking what the effect of its competition on the Courier would be.

35 Indeed, the Commission expressly approved the existing intent requirement, REPORT, supra note 2, at 146, which would remain an important element under the proposed legislation.

36 Report, supra note 2, at 146, 169 n.16.

37 In a few cases there was extrinsic evidence of intent-putative "smoking guns" such as memoranda or recollected comments-although such evidence is rarely dispositive. See, e.g., Janich Bros. v. American Distilling Co., 570 F.2d 848, 859-60 (9th Cir. 1977), cert. denied, 439 U.S. 829 (1978). See generally Hawk, Attempts to Monopolize-Specific Intent as Antitrust's Ghost in the Machine, 58 CoRnel. L. REv. 1121, 1136-49 (1973).

38 See L. Sullivan, ANTrtrust 135 (1977) ("the most important evidence [of intent] will be the defendant's conduct") (citing cases); Hawk, supra note 37, at $1148-49$.

39 United States Supreme Court: United States v. Columbia Steel Co., 334 U.S. 495 (1948); First Circuit: Transitron Elec. Corp. v. Hughes Aircraft Co., 487 F. Supp. 885 (D. Mass. 1980); Varney v. Coleman Co., 385 F. Supp. 1337 (D.N.H. 1974); Union Leader Corp. v. Newspapers of New England, Inc., 180 F. Supp. 125 (D. Mass.), modified, 284 F.2d 582 (1st Cir. 1960), cert. denied, 365 U.S. 833 (1961); Second Circuit: Flair Zipper Corp. v. Textron Inc., 1980-2 Trade Cas. โ 63,555 (S.D.N.Y. 1980); McDaniel v. General Motors Corp., 480 F. Supp. 666 (E.D.N.Y. 1979); Speed Auto Sales, Inc. v. American Motors Corp., 477 F. Supp. 1193 (E.D.N.Y. 1979); SCM Corp. v. Radio Corp. of Am., 318 F. Supp. 433 (S.D.N.Y. 1970); United States v. Singer Mfg. Co., 205 F. Supp. 394 (S.D.N.Y. 1962), rev'd on other grounds, 374 U.S. 174 (1963); Third Circuit: Webber v. Wynne, 431 F. Supp. 1048 (D.N.J. 1977); Mogul v. General Motors Corp., 391 F. Supp. 1305 (E.D. Pa. 1975), aff'd, 527 F.2d 645 (3d Cir. 1976); Fourth Circuit: McElhenny Co. v. Western Auto Supply Co., 269 F.2d 332 (4th Cir. 1959); Nelligan v. Ford Motor Co., 262 F.2d 556 (4th Cir. 1959); Human Resources Inst. of Norfolk, Inc. v. Blue Cross, 484 F. Supp. 520, 529 n.5 (E.D. Va. 1980); Fifth Circuit: Pinder v. Hudgins Fish Co., 570 F.2d 1209 (5th Cir. 1978); International Tel. \& Tel. Corp. v. United Tel. Co., 550 F.2d 287 (5th Cir. 1977); Kershaw v. Kershaw Mfg. Co., 209 F. Supp. 447 (M.D. Ala. 1962), aff'd, 327 F.2d 1002 (5th Cir. 1964); Sixth Circuit: Southern Blowpipe \& Roofing Co. v. Chattanooga Gas Co., 360 F.2d 79 (6th Cir. 1966), cert. denied, 393 U.S. 844 (1968); International Visible Sys. Corp. v. Remington-Rand, Inc., 65 F.2d 540 (6th Cir. 1933); Pennwalt Corp. v. Zenith Labs., Inc., 472 F. Supp. 413 (E.D. Mich. 1979); Seventh Circuit: Chillicothe Sand \& Gravel Co. v. Martin Marietta Corp., 615 F.2d 427 (7th Cir. 1980); South End Oil Co. v. Texaco, Inc., 237 F. Supp. 650 (N.D. Ill. 1965); Eighth Circuit: Morton Bldgs. of Neb., Inc. v. Morton Bldgs., Inc., 531 F.2d 910 (8th Cir. 1976); Central Savs. \& Loan Ass'n v. Federal Home Loan Bank Bd., 422 
For example, in Janich Bros. v. American Distilling Co., ${ }^{40}$ plaintiff predicated its attempted monopolization charge on allegations of price discrimination and predatory pricing, but failed to prove that either of these activities ever took place. Similarly, in Cowley $v$. Braden Industries, Inc., ${ }^{41}$ plaintiff based its section 2 claim on defendant's imposition of vertical territorial restraints, but the restraints were held reasonable and the attempted monopolization claim necessarily failed. It is not surprising that anticompetitive conduct remains an essential element of the offense in the Commission's recommendations; no amount of proof of intent or market power can suffice to establish attempted monopolization without evidence that defendant actually committed anticompetitive acts of serious dimension. ${ }^{42}$

The Commission's criticism of existing law focused not upon intent or conduct but instead upon the dangerous probability requirement and its alleged role in denying recovery to otherwise deserving plaintiffs. In twenty-eight of the attempt cases won by defendants, decision rested primarily on the failure of the plaintiff to prove a dangerous probability of success. ${ }^{43}$ In most of these

F.2d 504 (8th Cir. 1970); Ninth Circuit: Cowley v. Braden Indus., Inc., 613 F.2d 751 (9th Cir. 1980); California Computer Prods. v. IBM, 613 F.2d 727 (9th Cir. 1979); Naify v. McClatchy Newspapers, 599 F.2d 335 (9th Cir. 1979); Marquis v. Chrysler Corp., 577 F.2d 624 (9th Cir. 1978); Janich Bros. v. American Distilling Co., 570 F.2d 848 (9th Cir. 1977), cert. denied, 439 U.S. 829 (1978); Mutual Fund Investors, Inc. v. Putnam Mgt. Co., 553 F.2d 620 (9th Cir. 1977); Dahl, Inc. v. Roy Cooper Co., 448 F.2d 17 (9th Cir. 1971); General Business Sys. v. North Am. Philips Corp., 1980-1 Trade Cas. I6 63,607 (N.D. Cal. 1980); Fast Food Fabricators v. McDonald's Corp., 1980-2 Trade Cas. (f 63,552 (N.D. Cal. 1980); Filmamatic Corp. v. General Electric Co., 1980-2 Trade Cas. $\{63,417$ (N.D. Cal. 1980); Foremost Int'l Tours, Inc. v. Qantas Airways Ltd., 478 F. Supp. 589 (D. Hawaii 1979); In re Western Liquid Asphalt, 478 F. Supp. 785 (N.D. Cal. 1979); Pure Water Resources, Inc. v. Consolidated Foods Corp., 1980-1 Trade Cas. T63,064 (N.D. Cal. 1979); California Steel \& Tube v. Kaiser Steel Corp., 469 F. Supp. 265 (C.D. Cal. 1979); William Inglis \& Sons Baking v. ITT Continental Baking Co., 461 F. Supp. 410 (N.D. Cal. 1978); Zoslaw v. CBS, Inc., 1978-2 Trade Cas. (f 62,269 (N.D. Cal. 1978); Tenth Circuit: Pacific Eng'r \& Prod. Co. v. KerrMcGee Corp., 551 F.2d 790 (10th Cir.), cert. denied, 434 U.S. 879 (1977). See also E.I. DuPont de Nemours \& Co., [1980] 3 Trade REg. ReP. (CCH) 121,770 (FTC) (decided under $\$ 5$ of the FTC Act, but applying Sherman Act principles). 40570 F.2d 848 (9th Cir. 1977), cert. denied, 439 U.S. 829 (1978).

41613 F.2d 751 (9th Cir. 1980).

42 As the Commission recognized, "[a]n overt act is, of course, . . . necessary," although courts do not always list it as a separate element and it has become a "perfunctory requirement" of the offense. REPORT, supra note 2, at 169 n.I5 (citation omitted). See also Californla Computer Prods., Inc. v. IBM, 613 F.2d 727 (9th Cir. 1979) (anticompetitive conduct is measured by same "reasonableness" standard that applies under section 1 of the Sherman Act).

43 First Circuit: George R. Whitten, Jr., Inc. v. Paddock Pool Bldrs., Inc., 508 F.2d 547 (1st Cir. 1974), cert. denied, 421 U.S. 1004 (1975); Walker v. Providence Journal Co., 493 F.2d 82 (1st Cir. 1974); Varney v. Coleman Co., 385 F. Supp. 1337 (D.N.H. 1974); Second Circuit: Nifty Foods Corp. v. Great Ảtl. \& 
cases, however, the plaintiff alleged an unrealistically narrow "market" and failed to present evidence of any more meaningful market in the alternative.44' In nine cases virtually no market evidence was adduced at all. ${ }^{45}$ For example, in E.J. Delaney Corp. $v$.

Pac. Tea Co., 614 F.2d 832 (2d Cir. 1980); Syracuse Broadcasting Corp. v. Newhouse, 236 F.2d 522 (2d Cir. 1956); McDaniel v. General Motors Corp., 440 F. Supp. 666 (E.D.N.Y. 1979); Unibrand Tire \& Prod. Co. v. Armstrong Rubber Co., 429 F. Supp. 470 (W.D.N.Y. 1977); Diehl \& Sons v. International Harvester Co., 426 F. Supp. 110 (E.D.N.Y. 1976); Third Circuit: Edward J. Sweeney \& Sons v. Texaco, Inc., 1980-1 Trade Cas. $[63,611$ (3d Cir. 1980); Coleman Motor Co. v. Chrysler Corp., 525 F.2d 1338 (3d Cir. 1975); Fourth Circuit: Advance Bus. Sys. \& Supply Co. v. SCM Corp., 415 F.2d 55 (4th Cir. 1969), cert. denied, 397 U.S. 920 (1970); Diamond Int'l Corp. v. Walterhoefer, 289 F. Supp. 550 (D. Md. 1968); Fifth Circuit: Spectrofuge Corp. v. Beckman Instrs., Inc., 575 F.2d 256 (5th Cir. 1978); Yoder Bros. v. California-Florida Plant Corp., 537 F.2d 1347 (5th Cir. cert. denied, 429 U.S. 1094 (1976); Scranton Constr. Co. v. Litton Indus. Leasing Corp., 494 F.2d 778 (5th Cir. 1974), cert. denied, 419 U.S. 1105 (1975); Cal Distrib. Co. v. Bay Distribs. Inc., 337 F. Supp. 1154 (M.D. Fla. 1971); Sixth Circuit: Volasco Prods. Co. v. Lloyd A. Fry Roofing Co., 308 F.2d 383 (6th Cir. 1962), cert. denied, 372 U.S. 907 (1963); Copperstone v. Griswold Sporting Goods Co. 1977-2 Trade Cas. I 61,623 (E.D. Mich. 1977); Allen Ready Mix Concrete Co. v. John A. Denie's Sons Co., 1972 Trade Cas. 773,955 (W.D. Tenn. 1972); Seventh Circuit: Mackey v. Sears, Roebuck \& Co., 237 F.2d 869 (7th Cir. 1956); Tapeswitch Corp. of Am. v. Recora Co., 1977-2 Trade Cas. I 61,584 (N.D. III. 1977); Tire Sales Corp. v. Cities Serv. Oil Co., 410 F. Supp. 1222 (N.D. III. 1976); Eighth Circuit: United States v. Empire Gas Corp., 537 F.2d 296 (8th Cir. 1976), cert. denied, 429 U.S. 1122 (1977); Acme Precision Prods. Inc. v. American Alloys Corp., 484 F.2d 1237 (8th Cir. 1973); Ninth Circuit: Walker Distrib. Co. v. Lucky Lager Brewing Co., 323 F.2d 1 (9th Cir. 1963), cert. denied, 385 U.S. 976 (1966); Tenth Circuit: Perington Wholesale, Inc. v. Burger King Corp., 1979-2 Trade Cas. \62,986 (10th Cir. 1979); E.J. Delaney Corp. v. Bonne Belle, Inc., 525 F.2d 296 (10th Cir. 1975), cert. denied, 425 U.S. 907 (1976); Becker v. Safelite Glass Corp., 244 F. Supp. 625 (D. Kan. 1965).

44 In several cases the rejected "market" consisted of a single brand. E.g., Edward J. Sweeney \& Sons v. Texaco Inc., 1980-1 Trade Cas. T63,611 at 77,235-36 (3d Cir. 1980); Neugebauer v. A.S. Abell Co., 474 F. Supp. 1053, 1058-66 (D. Md. 1979) (citing cases). There have been cases, however, in which the courts have found that a supplier's brand may constitute a relevant market by itself. E.g., Jennings Oil Co. v. Mobil Oil Corp., 1979-2 Trade Cas. If 62,826, at 78,778 n.6 (S.D.N.Y. 1979) (and cases cited therein).

45 Edward J. Sweeney \& Sons v. Texaco, Inc., 1980-1 Trade Cas. $\int 63,611$ (3d Cir. 1980); Perington Wholesale, Inc. v. Burger King Corp., 1979-2 Trade Cas. If 62,986 (10th Cir. 1979); Spectrofuge Corp. v. Beckman Instrs., 575 F.2d 256 (5th Cir. 1978); Scranton Constr. Co. v. Litton Indus. Leasing Corp., 494 F.2d 778 (5th Cir. 1974), cert. denied, 419 U.S. 1105 (1975); Walker v. Providence Journal Co., 493 F.2d 82 (1st Cir. 1974); Acme Precision Prods. Inc. v. American Alloys Corp., 484 F.2d 1237 (8th Cir. 1973); MeDaniel v. General Motors Corp., 480 F. Supp. 666 (E.D.N.Y. 1979); Tapeswitch Corp. of Am. v. Recora Co., 1977-2 Trade Cas. I 61,584 (N.D. IIl. 1977); Becker v. Safelite Glass Corp., 244 F. Supp. 625 (D. Kan. 1965). See also Flair Zipper Corp. v. Textron Inc., 1980-2 Trade Cas. I 63,555 (S.D.N.Y. 1980).

Indeed, in several cases plaintiff failed even to allege a dangerous probability of success. Walker Distrib. Co. v. Lucky Lager Brewing Co., 323 F.2d I (9th Cir. 1963), cert. denied, 385 U.S. 976 (1966); Mackey v. Sears, Roebuck \& Co., 237 F.2d 869 (7th Cir. 1956); Unibrand Tire \& Prod. Co. v. Armstrong Rubber Co., 429 F. Supp. 470 (W.D.N.Y. 1977). See also Coca Cola Co. v. Howard Johnson Co., 386 F. Supp. 330 (N.D. Ga. 1974), discussed at text accompanying notes 164-65 infra. 
Bonne Belle, Inc., ${ }^{46}$ the court remarked with incredulity that although a "market" for skier's cosmetics had been alleged:

The record ... shows only that there were at the time some five million skiers in the country who were affluent and youthful; that the market was sought after, and that there were unique marketing problems. This was all that was shown as to the market as such. There was no evidence offered as to the corporate defendant's sales volume in the "skier's cosmetic market" nor the sales volume therein of anyone else. There was no evidence as to the total sales in the market. ${ }^{47}$

Manifestly, the dangerous probability element could not be established in cases such as this, in which the plaintiff failed to define the market that the defendant might ultimately have succeeded in monopolizing.

Many of the remaining cases in which defendants prevailed on the basis of dangerous probability concerned extremely low market shares. ${ }^{48}$ In these situations the "risk" of monopoly, even under the Commission's less exacting standard, was virtually nonexistent. In George R. Whitten, Jr., Inc. v. Paddock Pool Builders, Inc., ${ }^{49}$ for example, defendant possessed only 2.7 percent of the relevant market, and the alleged attempt to eliminate the plaintiff could have raised this share to no more than three percent. In many cases, a single brand is claimed to constitute the relevant market; when the court includes other brands within the area of effective competition, however, the defendant's market share shrinks dras-

46525 F.2d 296 (10th Cir. 1975), cert. denied, 425 U.S. 907 (1976).

47 Id. 306 (emphasis in original).

48 Yoder Bros. v. California-Florida Plant Corp., 537 F.2d 1347 (5th Cir.) (under 20\%; low entry barriers; market was "highly competitive"), cert. denied, 429 U.S. 1094 (1976); George R. Whitten, Jr., Inc. v. Paddock Pool Bldrs., Inc., 508 F.2d 547 (1st Cir. 1974) (2.7\%), cert. denied, 421 U.S. 1004 (1975); Volasco Prods. Co. v. Lloyd A. Fry Roofing Co., 308 F.2d 383 (6th Cir. 1962) (12.2\%), cert. denied, 372 U.S. 907 (1963); Syracuse Broadcasting Corp. v. Newhouse, 236 F.2d 522 (2d Cir. 1956) (defendant's market share "too low" to support any inference of an attempt offense); Diehl \& Sons v. International Harvester Co., 426 F. Supp. 110 (E.D.N.Y. 1976) (5-13\%); Tire Sales Corp. v. Cities Serv. Oil Co., 410 F. Supp. 1222 (N.D. IIl. 1976) ("defendant's share of the . . market is extremely small"); Varney v. Coleman Co., 385 F. Supp. 1337 (D.N.H. 1974) (under 2\%); Cal Distrib. Co. v. Bay Distribs., Inc., 337 F. Supp. 1154 (M.D. Fla. 1971) (under 18\%).

In Advance Bus. Sys. \& Supply Co. v. SCM Corp., 415 F.2d 55 (4th Cir. 1969) the defendant was charged with attempting to monopolize the market for the sale of office copier paper. The court, however, noted that defendant sold paper only for use in its own brand of office copiers, and that defendant controlled only 13\% of the relevant office copier market. 415 F.2d at 60,69 .

49508 F.2d 547, 555 (Ist Cir. 1974), cert. denied, 421 U.S. 1004 (1975). 
tically. For example, in Diehl \& Sons v. International Harvester Co., ${ }^{50}$ plaintiff charged that the relevant market was defendant's brand of trucks. ${ }^{51}$ The court observed that the market actually consisted either of all trucks, where defendant's share was less than five percent, or at best of a "heavy-duty" truck submarket, where this share was still under thirteen percent. ${ }^{52}$

Upon exclusion of those cases in which defendants had a very low market share, ${ }^{63}$ or in which the plaintiffs failed to correctly define the market ${ }^{54}$-cases in which the plaintiffs would not prevail even under the Commission's less stringent standard-it appears that, in the last seventy-five years, only a handful of cases are even arguably subject to the Commission's criticism that the dangerous probability requirement has denied antitrust recovery in otherwise meritorious suits. Indeed, close examination suggests that none of these cases genuinely supports the Commission's claim. ${ }^{55}$ Against this backdrop, the Commission's criticisms of the present state of attempted monopolization law clearly appear misleading and unwarranted. Its proposal for change is, at best, unnecessary.

\section{The Conduct Challenged}

The Commission, of course, focused its attention less upon those defendants whose market share created an actual "risk" of monopoly than upon those defendants that exhibited conduct so predatory and vicious that-regardless of market share-their activities should be prohibited. Most of the conduct challenged in attempted monopolization cases, however, is neither predatory nor

50426 F. Supp. 110 (E.D.N.Y. 1976).

31 Id. 120.

52 Id. $120,122$.

53 See note 48 supra.

64 See note 45 supra.

55 Our research has revealed only one case in which a court, after finding anticompetitive conduct and specific intent to monopolize, held that a defendant with more than a de minimis market share did not have a dangerous probability of success. The Commission cited United States v. Empire Gas Corp., 537 F.2d 296 (8th Cir. 1976), cert. denied, 429 U.S. 1122 (1977). For a detailed discussion of the case, see text accompanying notes 78-103 infra.

In two cases, decision rested solely on the dangerous probability requirement; the issues of anticompetitive conduct or intent were not reached. Had the courts reached these issues, however, they would doubtless have resolved them in favor of the defendants. In Nifty Foods Corp. v. Great Atl. \& Pac. Tea Co., 614 F.2d 832 (2d Cir. 1980), the plaintiff, the sole supplier of frozen waffles to a supermarket chain, was terminated. The facts of the case strongly suggest that neither anticompetitive conduct nor specific intent could have been shown. And in Allen Ready Mix Concrete Co. v. John A. Denie’s Sons Co., 1972 Trade Cas. I 73,955 (W.D. Tenn. 1972), the court strongly suggested, and arguably held, that defendants had not engaged in anticompetitive conduct. 
vicious; again, the Commission's concern appears to be misplaced. The alleged anticompetitive conduct assailed in these suits has fallen, with a few exceptions, into six categories, few of which fit the Commission's description:

1. Disputes between a supplier and its distributors arising out of termination of a distributor, entry by the supplier into competition with its distributors, or discrimination by the supplier in favor of its wholly-owned distributors. This has become the most common variety of attempted monopolization suit by far; over sixty such cases have been reported ${ }^{56}$ and unquestionably many others.

56 First Circuit: Walker v. Providence Journal Co., 493 F.2d 82 (1st Cir. 1974); Varney v. Coleman Co., 385 F. Supp. 1337 (D.N.H. 1974); Second Circuit: Nifty Foods Corp. v. Great Atl. \& Pac. Tea Co., 614 F.2d 832 (2d Cir. 1980); Buffalo Courier-Express, Inc. v. Buffalo Evening News, Inc., 601 F.2d 48 (2d Cir. 1979); Syracuse Broadcasting Corp. v. Newhouse, 236 F.2d 522 (2d Cir. 1956); McDaniel v. General Motors Corp., 480 F. Supp. 666 (E.D.N.Y. 1979); Speed Auto Sales, Inc. v. American Motors Corp., 474 F. Supp. 1193 (E.D.N.Y. 1979); Air Freight Haulage Co. v. Ryd-Air Inc., 1978-2 Trade Cas. [ 62,321 (S.D.N.Y. 1978), aff'd mem., 603 F.2d 211 (2d Cir.), cert. denied, 444 U.S. 917 (1979); Fuchs Sugars \& Syrups, Inc. v. Amstar Corp., 447 F. Supp. 867 (S.D.N.Y. 1978), rev'd on other grounds, 602 F.2d 1025 (2d Cir.), cent. denied, 444 U.S. 864 (1979); Giant Paper \& Film Corp. v. Albemarle Paper Co., 430 F. Supp. 981 (S.D.N.Y. 1977); Unibrand Tire \& Prod. Co. v. Armstrong Rubber Co., 429 F. Supp. 470 (W.D.N.Y. 1977); American Bd. of Trade v. American Stock Exch., 430 F. Supp. 655 (S.D.N.Y. 1977); Diehl \& Sons v. International Harvester Co., 426 F. Supp. 110 (E.D.N.Y. 1976); United States v. Airco, Inc., 386 F. Supp. 915 (S.D.N.Y. 1974); Bowen v. New York News, Inc., 366 F. Supp. 651 (S.D.N.Y. 1973), aff'd in part and rev'd in part, 522 F.2d 1242 (2d Cir. 1975), cert. denied, 425 U.S. 936 (1976); Sam S. Goldstein Indus., Inc. v. Botany Indus., Inc., 301 F. Supp. 728 (S.D.N.Y. 1969); Third Circuit: Edward J. Sweeney \& Sons v. Texaco, Inc., 1980-1 Trade Cas. If 63,611 (3d Cir. 1980); Harold Friedman, Inc. v. Kroger Co., 581 F.2d 1068 (3d Cir. 1978); Carlo C. Gelardi Corp. v. Miller Brewing Co., 421 F. Supp. 237 (D.N.J. 1976); Keco Indus., Inc. v. Borg-Warner Corp., 334 F. Supp. 1240 (M.D. Pa. 1971); Mt. Lebanon Motors, Inc. v. Chrysler Corp., 283 F. Supp. 453 (W.D. Pa. 1968), aff'd per curiam, 417 F.2d 622 (3d Cir. 1969); Fourth Circuit: White Bag Co. v. International Paper Co., 579 F.2d 1384 (4th Cir. 1974); Ray v. United Family Life Ins. Co., 430 F. Supp. 1353 (W.D.N.C. 1977); Campbell Distrib. Co. v. Jos. Schlitz Brewing Co., 208 F. Supp. 523 (D. Md. 1962); Fifth Circuit: Pinder v. Hudgins Fish Co., 570 F.2d 1209 (5th Cir. 1978); Scranton Constr. Co. v. Litton Indus. Leasing Corp., 494 F.2d 778 (5th Cir. 1974); cert. denied, 419 U.S. 1105 (1975); Cliff Food Stores, Inc. v. Kroger, Inc., 417 F.2d 203 (5th Cir. 1969); Bowmar Instr. Corp. v. Texas Instrs., Inc., No. 74-137 (S.D. Tex., filed March 30, 1978); Joe Westbrook, Inc. v. Chrysler Corp., 419 F. Supp. 824 (N.D. Ga. 1976); Sixth Circuit: Alles Corp. v. Senco Prods., Inc., 329 F.2d 567 (6th Cir. 1964); Ace Bee Distrib., Inc. v. Kohn, Inc., 318 F.2d 283 (6th Cir.), cert. denied, 375 U.S. 922 ( 1963 ); Pennwalt Corp. v. Zenith Labs., Inc., 472 F. Supp. 413 (E.D. Mich. 1979); Copperstone v. Griswold Sporting Goods Co., 1977-2 Trade Cas. If 61,623 (E.D. Mich. 1977); Oak Distrib. Co. v. Miller Brewing Co., 370 F. Supp. 889 (E.D. Mich. 1973); Zenith Vinyl Fabrics Corp. v. Ford Motor Corp., 357 F. Supp. 133 (E.D. Mich. 1973), aff'd, No. 73-1537 (6th Cir., filed June 6, 1974) ("not for publication"), cert. denied, 419 U.S. 967 (1974); Huron Valley Publ. Co. v. Booth Newspapers, Inc., 336 F. Supp. 659 (E.D. Mich. 1972); Seventh Circuit: Sargent-Welch Scientific Co. v. Ventron Corp., 567 F.2d 701 (7th Cir. 1977), cert. denied, 439 U.S. 822 (1978); Mullis v. Arco Petroleum Co., 502 F.2d 290 (7th Cir. 1974); Mackey v. Sears, Roebuck \& Co., 237 F.2d 869 (7th Cir. 
have been filed without resulting in judicial decisions. To discourage spurious claims, which have been common in this type of litigation, Judge Morgan in the Fifth Circuit has warned:

Lest any other former distributors succumb to the tempation of treble damages, we reiterate that it is simply not an antitrust violation for a manufacturer to contract with a new distributor, and as a consequence, to terminate his relationship with a former distributor, even if the effect of the new contract is to seriously damage the former distributor's business. ${ }^{.7}$

2. Refusals to deal or encouragement of others to so refuse. There have been at least twenty-nine such cases. ${ }^{58}$ In Daily Press,

1956); Tire Sales Corp. v. Cities Serv. Oil Co., 410 F. Supp. 1222 (N.D. Ill. 1976); Radzik v. Chicagoland Rec. Vehicle Dealers Ass'n, 1972 Trade Cas. T74,167 (N.D. Ill. 1972); Brewer Sewing Supplies Co. v. Fritz Gegauf, Ltd., 1970 Trade Cas. II 73,139 (N.D. IIl. 1970); Eighth Circuit: Morton Bldgs. of Neb., Inc. v. Morton Bldgs., Inc., 333 F. Supp. 187 (D. Neb. 1971), affd in relevant part and reversed on other grounds, 531 F.2d 910 (8th Cir. 1976); McCormack v. Theo. Hamm Brewing Co., 284 F. Supp. 158 (D. Minn. 1968); Ninth Circuit: Sherman v. British Leyland Motors, Ltd., 601 F.2d 429 (9th Cir. 1979); Naify v. McClatchy Newspapers, 599 F.2d 335 (9th Cir, 1979); Marquis v. Chrysler Corp., 577 F.2d 624 (9th Cir. 1978); Moore v. Jas. H. Matthews \& Co., 550 F.2d 1207 (9th Cir. 1977); Knutson v. Daily Review, Inc., 548 F.2d 795 (9th Cir. 1976), cert. denied, 433 U.S. 910 (1977); Pacific Coast Agr. Export Ass'n v. Sunkist Growers, Inc., 526 F.2d 1196 (9th Cir. 1975), cert. denied, 425 U.S. 959 (1976); ALW, Inc. v. United Air Lines, Inc., 510 F.2d 52 (9th Cir. 1975); Trixler Brokerage Co. v. Ralston Purina Co., 505 F.2d 1045 (9th Cir. 1974); Cornwell Quality Tools Co. v. C.T.S. Co., 446 F.2d 825 (9th Cir. 1971), cert. denied, 404 U.S. 1049 (1972); Industrial BIdg. Materials, Inc. v. Interchemical Corp., 437 F.2d 1336 (9th Cir. 1970); Hiland Dairy Inc. v. Kroger Co., 402 F.2d 968 (9th Cir. 1968), cert. denied, 395 U.S. 961 (1969); Lessig v. Tidewater Oil Co., 327 F.2d 459 (9th Cir.), cert. denied, 377 U.S. 993 (1964); Walker Distrib. Co. v. Lucky Lager Brewing Co., 323 F.2d 1 (9th Cir. 1963), cert. denied, 385 U.S. 976 (1966); Determined Prods., Inc. v. R. Dakin \& Co., 1980-1 Trade Cas. \63,063 (N.D. Cal. 1979); California Steel \& Tube v. Kaiser Steel Corp., 469 F. Supp. 265 (C.D. Cal. 1979); Blair Foods, Inc. v. Ranchers Cotton Oil, 1977-2 Trade Cas. If 61,576 (N.D. Cal. 1977), aff'd, 610 F.2d 665 (9th Cir. 1980); General Comm's Eng'r, Inc. v. Motorola Comm's \& Elecs., Inc., 421 F. Supp. 274 (N.D. Cal. 1976); Tenth Circuit: Becker v. Safelite Glass Corp., 244 F. Supp. 625 (D. Kan. 1965); District of Columbia Circuit: Merit Motors, Inc. v. Chrysler Corp., 417 F. Supp. 263 (D.D.C. 1976), aff'd, 569 F.2d 666 (D.C. Cir. 1977).

Most attempted monopolization cases involve charges of more than one type of conduct. The classification in this note and in the notes that follow is based on the most significant allegations in each action.

57 Burdett Sound, Inc. v. Aitec Corp., 515 F.2d 1245, 1249 (5th Cir. 1975) (citations omitted).

58 First Circuit: Walker v. Providence Journal Co., 493 F.2d 82 (1st Cir. 1974); Second Circuit: Levitch v. CBS, Inc., 495 F. Supp. 649 (S.D.N.Y. 1980); Paralegal Inst. Inc. v. American Bar Ass'n, 1980-1 Trade Cas. đ 63,096 (E.D.N.Y. 1979); Giant Paper \& Film Corp. v. Albemarle Paper Co., 430 F. Supp. 981 (S.D.N.Y. 1977); Diehl \& Sons v. International Harvester Co., 426 F. Supp. 110 (E.D.N.Y. 1976); Third Circuit: Columbia Metal Culvert Co. v. Kaiser Alum. \& Chem. Corp., 579 F.2d 20 (3d Cir.), cert. denied, 439 U.S. 876 (1978); N.W. Controls, Inc. v. Outboard Marine Corp., 333 F. Supp. 493 (D. Del. I971); 
Inc. v. United Press International, ${ }^{59}$ for example, an interim newspaper, organized solely to publish during a strike which idled Detroit's regular papers, sought unsuccessfully to obtain special, short-run terms from a major wire service. The service refused to deal except on its normal terms and the court affirmed the grant of summary judgment in its favor, explaining: "It is settled that mere refusal to deal is not a violation per se of Section 2." 60 Since unilateral refusals to deal do not contravene section 1 of the Sherman Act, there being no conspiracy, ${ }^{61}$ proof that such refusals represent attempts to monopolize is often the only means for establishing antitrust liability in such cases. Of course the refusals by themselves cannot provide the basis of a section 2 violation; the other elements of the offense must still be proved. ${ }^{62}$

United States v. Jerrold Elecs. Corp., 187 F. Supp. 545 (E.D. Pa. 1960), aff'd per curiam, 365 U.S. 567 (1961); Fourth Circuit: White Bag Co. v. International Paper Co., 579 F.2d 1384 (4th Cir. 1974); McElhenney Co. v. Western Auto Supply Co., 269 F.2d 332 (4th Cir. 1959); Fifth Circuit: Six Twenty-Nine Prods., Inc. v. Rollins Telecasting, Inc., 365 F.2d 478 (5th Cir. 1966); North Tex. Prods. Ass'n v. Metzger Dairies, Inc., 348 F.2d 189 (5th Cir. 1965), cert. denied, 382 U.S. 977 (1966); Southeastern Hose, Inc. v. Imperial-Eastman Corp., 1973-1 Trade Cas. I74,479 (N.D. Ga. 1973); Sixth Circuit: Daily Press, Inc. v. United Press Int'l, 412 F.2d 126 (6th Cir.), cert. denied, 398 U.S. 990 (1969); Copperstone v. Griswold Sporting Goods Co., 1977-2 Trade Cas. f61,623 (E.D. Mich. 1977); Zenith Vinyl Fabrics Corp. v. Ford Motor Corp., 357 F. Supp. 133 (E.D. Mich. 1973), aff'd, No. 73-1537 (6th Cir., filed June 6, 1974) ("not for publication"), cert. denied, 419 U.S. 967 (1974); Seventh Circuit: Brewer Sewing Supplies Co. v. Fritz Gegauf, Ltd., 1970 Trade Cas. If 73,139 (N.D. III. 1970); South End Oil Co. v. Texaco Inc., 237 F. Supp. 650 (N.D. III. 1965); Eighth Circuit: Kansas City Star Co. v. United States, 240 F.2d 643 (8th Cir.), cert. denied, 354 U.S. 923 (1957); United States v. Klearflax Linen Looms, Inc., 63 F. Supp. 32 (D. Minn. 1945); Ninth Circuit: Mutual Fund Investors, Inc. v. Putnam Mgt. Co., 553 F.2d 620 (9th Cir. 1977); Moore v. Jas H. Matthews \& Co., 550 F.2d 1207 (9th Cir. 1977); Case-Swayne Co. v. Sunkist Growers, Inc., 369 F.2d 449 (9th Cir. 1966), rev'd on other grounds, 389 U.S. 384 (1967); Jerrold Elecs. Corp. v. Wescoast Broadcasting Co., 341 F.2d 653 (9th Cir.), cert. denied, 382 U.S. 817 (1965); Independent Iron Works, Inc. v. United States Steel Corp., 322 F.2d 656 (9th Cir.), cert. denied, 375 U.S. 922 (1963); General Business Sys. v. North Am. Philips Corp., 1980-1 Trade Cas. If 63,607 (N.D. Cal. 1980); Fast Food Fabricators v. McDonald's Corp., 1980-2 Trade Cas. If 63,552 (N.D. Cal. 1980); Zoslaw v. CBS, Inc., 1978-2 Trade Cas. $\llbracket 62,269$ (N.D. Cal. 1978); District of Columbia Circuit: Filmdex Chex Sys., Inc. v. Telecheck Wash., Inc., 1979-2 Trade Cas. If 62,976 (D.D.C. 1979).

59412 F.2d 126 (6th Cir.), cert. denied, 396 U.S. 990 (1969).

60 Id. 134 (citing First Nat'l Bank v. Cities Serv. Co., 391 U.S. 253 (1968)). The court found further that there was "an entire failure of proof on the monopoly issue," id. 135, with no evidence of market power or specific intent.

61 See, e.g., United States v. Amold, Schwinn \& Co., 388 U.S. 365, 376 (1967); United States v. Colgate \& Co., 250 U.S. 300, 307 (1919); Nifty Foods Corp. v. Great Atl. \& Pac. Tea Co., 614 F.2d 832 (2d Cir. 1980); Oreck Corp. v. Whirlpool Corp., 579 F.2d 126, 129 n.4, 130, 133-34 (2d Cir.), cert. denied, 439 U.S. 946 (1978).

62 See Otter Tail Power Co. v. United States, 410 U.S. 366 (1973); Lorain Journal v. United States, 342 U.S. 143 (1951); Eastman Kodak Co. v. Southern 
3. Predatory pricing in an attempt to drive the plaintiff out of business. There have been at least twenty-five such cases. ${ }^{63}$ Plaintiffs commonly focus on identifying the appropriate measure of cost and attempt to prove that defendant's prices were set below this level. Predatory pricing has attracted a great deal of interest in recent years ${ }^{64}$ and was one of the subjects addressed in the

Photo Materials Co., 273 U.S. 359 (1927); Byars v. Bluff City News Co., 609 F.2d 843 (6th Cir. 1979); Poster Exch., Inc. v. National Screen Serv. Corp., 431 F.2d 334 (5th Cir. 1970), cert. denied, 401 U.S. 912 (1971); Filmdex Chex Sys., Inc. v. Telecheck Wash., Inc., 1979-2 Trade Cas. If 62,976 (D.D.C. 1979); United States v. Klearflax Linen Looms, Inc., 63 F. Supp. 32 (D. Minn. 1945).

63 Second Circuit: Buffalo Courier-Express, Inc. v. Buffalo Evening News, Inc., 601 F.2d 48 (2d Cir. 1979); Northeastern Tel. Co. v. American Tel. \& Tel. Co., 1980-I Trade Cas. $\int 63,593$ (D. Conn. 1980); Flair Zipper Corp. v. Textron Inc., 1980-2 Trade Cas. I6 63,555 (S.D.N.Y. 1980); Third Circuit: Gold Fuel Serv., Inc. v. Esso Standard Oil Co., 306 F.2d 61 (3d Cir. 1962), cert. denied, 371 U.S. 951 (1963); Outboard Marine Corp. v. Pezetel, 461 F. Supp. 384 (D. Del. 1978); Weber v. Wynne, 431 F. Supp. 1048 (D.N.J. 1977); Sixth Circuit: Southern Blowpipe \& Roofing Co. v. Chattanooga Gas Co., 360 F.2d 79 (6th Cir. 1966), cert. denied, 393 U.S. 844 (1968); Volasco Prods. Co. v. Lloyd A. Fry Roofing Co., 308 F.2d 383 (6th Cir. 1962), cert. denied, 372 U.S. 907 (1963); Allen Ready Mix Concrete Co. v. John A. Denie's Sons Co., 1972 Trade Cas. If 73,955 (W.D. Tenn. 1972); Huron Valley Publ. Co. v. Booth Newspapers, Inc., 336 F. Supp. 659 (E.D. Mich. 1972); Seventh Circuit: Chillicothe Sand \& Gravel Co. v. Martin Marietta Corp., 615 F.2d 427 (7th Cir. 1980); Eighth Circuit: Morning Pioneer, Inc. v. Bismarck Tribune Co., 493 F.2d 383 (8th Cir.), cert. denied, 419 U.S. 836 (1974); Bergijans Farm Dairy Co. v. Sanitary Milk Prods., 241 F. Supp. 476 (E.D. Mo. 1965), affd, 368 F.2d 679 (8th Cir. 1966); Ninth Circuit: Ernest W. Hahn, Inc. v. Codding, 615 F.2d 830 (9th Cir. 1980); California Computer Prods., Inc. v. IBM, 613 F.2d 727 (9th Cir. 1979); Janich Bros. v. American Distilling Co., 570 F.2d 848 (9th Cir. 1977), cert. denied, 439 U.S. 829 (1978); Knutson v. Daily Review Inc., 548 F.2d 795 (9th Cir. 1976), cert. denied, 433 U.S. 910 (1977); Cornwell Quality Tools Co. v. C.T.S. Co., 446 F.2d 825 (9th Cir. 1971), cert. denied, 404 U.S. 1049 (1972); Scott Publ. Co. v. Columbia Basin Publs, Inc., 293 F.2d 15 (9th Cir.), cert. denied, 368 U.S. 940 (1961); Roberts Waikiki U-Drive, Inc. v. Budget Rent-A-Car, Inc., 491 F. Supp. 1199 (D. Hawaii 1980); Foremost Int'l Tours, Inc. v. Qantas Airways, Ltd. 478 F. Supp. 589 (D. Hawaii 1979); William Inglis \& Sons Baking Co. v. ITT Cont. Baking Co., 461 F. Supp. 410 (N.D. Cal. 1978); Murphy Tugboat Co. v. Crowley, 454 F. Supp. 847 (N.D. Cal. 1978); Foremost Int'l Tours, Inc. v. Qantas Airways, Ltd., 379 F. Supp. 88 (D. Hawaii 1974), aff'd, 525 F.2d 281 (9th Cir. 1975), cert. denied, 429 U.S. 816 (1976); Tenth Circuit: Pacific Eng'r \& Prod. Co. v. Kerr-McGee Corp., 551 F.2d 790 (10th Cir.), cert. denied, 434 U.S. 879 (1977).

64 See, e.g., R. Bork, The Antrtrust Paradox 149-55 (1978); R. Posner, ANTtrrust Law: AN Economic Perspective 184-96 (1976); F. Scherer, Industriar Market Structure and Economito Performanance 537-38 (2d ed. 1980); Areeda \& Turner, Williamson on Predatory Pricing, 87 YArE L.J. 1337 (1978); Areeda \& Turner, Scherer on Predatory Pricing: A Reply, 89 Harv. L. REv. 891 (1976); Baumol, Quasi-Permanence of Price Reductions: A Policy for Prevention of Predatory Pricing, 89 YaLE L.J. 1 (1979); Blecher \& Stegman, Hanson v. Shell Oil Co.: A Straw in the Wind, 38 Oно Sт. L.J. 269 (1977); Greer, A Critique of Areeda \& Turner's Standard for Predatory Practises, 24 ANTrmust Bult. 233 (1979); Joskow \& Klevorick, A Framework for Analysing Predatory Pricing Policy, 89 Yale L.J. 213 (1979); Posner, The Chicago School of Antitrust Analysis, 127 U. PA. L. REv. 925, 939-44 (1979); Scherer, Predatory Pricing and the Sherman Act: A Comment, 89 Harv. L. Rev. 869 (1976); Scherer, Some Last Words on Predatory Pricing, 89 Harv. L. Rev. 90I (1976); Schmalensee, On the Use of 
Commission's report. The Commission paid particular attention to the definition of predatory pricing advanced by Professors Areeda and Turner, who argue that prices set above marginal cost (or its surrogate, average variable cost) generally should be presumed lawful, while prices set below this level should be presumed unlawful. ${ }^{65}$ The Commission recommended that the AreedaTurner test be applied only where there is no evidence of anticompetitive intent other than defendant's prices themselves, and that where additional evidence of intent is presented, "the fact that prices were above marginal cost should not absolutely bar a finding of liability."

4. Activities related to the use of a fraudulently or otherwise improperly secured or expired patent or to the misuse of a valid patent or trademark. There have been thirteen such cases, ${ }^{67}$ typically involving attempts to use an invalid patent to exclude competitors from a market, or attempts to broaden a legitimate patent monopoly through tying restrictions.

Economic Models in Antitrust: The Realemon Case, 127 U. PA. L. Rev. 994, 101631 (1979); Schwartz, On the Uses of Economics: A Review of the Antitrust Treatises, 128 U. PA. L. REv. 244, 253-57 (1979); Williamson, Predatory Pricing: A Strategic and Welfare Analysis, 87 YAIE L.J. 284 (1977); Williamson, Williamson on Predatory Pricing II, 88 YALE L.J. 1183 (1979); Comment, An Appraisal of. Marginal Cost and Predatory Pricing Under Section 2 of the Sherman Act, 30 ArA. L. REv. 562 (1979).

65 See 3 P. Areeda \& D. Turner, Antitrust Law If 711-22 (1978); Areeda \& Turner, Predatory Pricing and Related Practices Under Section 2 of the Sherman Act, 88 HaRv. L. REv. 697 (1975).

66 Report, supra note 2, at 150 . The Commission's "Proposed Competition Protection Act" includes a second proviso instructing that in determining whether a defendant has attempted to monopolize, "the fact that a defendant's prices were not below either average variable cost or marginal cost shall not be controlling, but may properly be considered, in assessing the defendant's intent and the conduct at issue." Id. 166.

67 Kearney \& Trecker Corp. v. Cincinnati Milacron, Inc., 562 F.2d 365 (6th Cir. 1977); Oetiker v. Jurid Werke G.m.b.H., 556 F.2d 1 (D.C. Cir. 1977); Yoder Bros. v. California-Florida Plant Corp., 537 F.2d 1347 (5th Cir.), cert. denied, 429 U.S. 1094 (1976); W. L. Gore \& Assoc. v. Carlisle Corp., 529 F.2d 614 (3d Cir. 1976); Acme Precision Prods., Inc. v. American Alloys Corp., 484 F.2d 1237 (8th Cir. 1973); Agrashell, Inc. v. Hammons Prods. Co., 479 F.2d 269 (8th Cir.), cert. denied, 414 U.S. 1022 (1973); Bendix Corp. v. Balax, Inc., 471 F.2d 149 (7th Cir. 1972), cert. denied, 414 U.S. 819 (1973); Kearney \& Trecker Corp. v. Giddings \& Lewis, Inc., 452 F.2d 579 (7th Cir. 1971), cert. denied, 405 U.S. 1066 (1972); Tapeswitch Corp. of Am. v. Recora Co., 1977-2 Trade Cas. If 61,584 (N.D. III. 1977); Vogue Ring Creations, Inc. v. Hardman, 410 F. Supp. 609 (D.R.I. 1976); Jack Winter, Inc. v. Koratron Co., 375 F. Supp. 1 (N.D. Cal. 1974); SCM Corp. v. Radio Corp. of Am., 318 F. Supp. 433 (S.D.N.Y. 1970); Diamond Int'l Corp. v. Walterhoefer, 289 F. Supp. 550 (D. Md. 1968). Similarly, trademark licenses may contain unlawful restrictions imposed in an effort to gain control of a relevant market. Jack Winter v. Koratron Co., 375 F. Supp. 1, 69-71 (N.D. Cal. 1974). 
5. Disparagement of plaintiffs or plaintiffs' products, drawing unfair comparison between such products or engaging in related acts of unfair competition. There have been fourteen such cases. ${ }^{88}$ Frequently, charges of unfair competition are combined with allegations of other illegal activity.

6. There is also a miscellany of acts and practices such as attempts to prevent commercial exploitation of plaintiff's product, ${ }^{69}$ institution of sham litigation, ${ }^{70}$ termination of a subcontractor relationship, ${ }^{71}$ excessive promotion of a product that competes with a product of the plaintiff, ${ }^{72}$ refusal to abandon a lease for a store sought by plaintiff,, ${ }^{73}$ unfair advertising campaigns, ${ }^{74}$ locating outlets in a manner calculated to siphon off plaintiff's business, ${ }^{75}$ and acquisition or expansion of unneeded facilities to harass a competitor. ${ }^{78}$

By far, the bulk of this conduct-with the possible exception of predatory pricing or the fraudulent procurement of patents-

68 Hunt-Wesson Foods, Inc. v. Ragu Foods, Inc., 627 F.2d 919 (9th Cir. 1980); Duckworth v. EMI Medical, Inc., 1980-2 Trade Cas. II 63,386 (8th Cir. 1980); Associated Radio Service Co. v. Page Airways, Inc., 624 F.2d 1342 (5th Cir. 1980); Cowley v. Braden Indus., 613 F.2d 751 (9th Cir.), cert. denied, 100 S. Ct. 2942 (1980); Bernard Food Indus., Inc. v. Dietene Co., 415 F.2d 1279 (7th Cir. 1969), cert. denied, 397 U.S. 912 (1970); Advance Bus. Sys. \& Supply Co. v. SCM Corp., 415 F.2d 55 (4th Cir. 1969), cert. denied, 397 U.S. 920 (1970); North Tex. Prods. Ass'n v. Metzger Dairies, Inc., 348 F.2d 189 (5th Cir. 1965), cert. denied, 382 U.S. 977 (1966); Syracuse Broadcasting Corp. v. Newhouse, 236 F.2d 522 (2d Cir. 1956); Blair Foods, Inc. v. Ranchers Cotton Oil, 1977-2 Trade Cas. If 61,576 (N.D. Ca. 1977), affd., 610 F.2d 665 (9th Cir. 1980); General Comm's Eng'r Inc. v. Motorola Comm's \& Elecs., Inc., 421 F. Supp. 274 (N.D. Cal. 1976); Oak Distribs. Co. v. Miller Brewing Co., 370 F. Supp. 889 (E.D. Mich. 1973); Power Replacements Corp. v. Air Preheater Co., 356 F. Supp. 872 (E.D. Pa. 1973); Keco Indus., Inc. v. Borg-Warner Corp., 334 F. Supp. 1240 (M.D. Pa. 1971); Smith-Victor Corp. v. Sylvania Elec. Prods., Inc., 242 F. Supp. 302 (N.D. Ill. 1965).

69 Kreager v. General Elec. Co., 497 F.2d 468 (2d Cir. 1974).

70 Associated Radio Service Co. v. Page Airways, Inc., 624 F.2d 1342 (5th Cir. 1980).

71 Air Freight Haulage Co. v. Ryd-Air Inc., 1978-2 Trade Cas. 162,321 (S.D.N.Y), affd, 603 F.2d 211 (2d Cir. 1978), cert. denied, 444 U.S. 864 (1980).

72 Buffalo Courier-Express, Inc. v. Buffalo Evening News, Inc., 601 F.2d 48 (2d Cir. 1979); Morning Pioneer, Inc. v. Bismarck Tribune Co., 493 F.2d 383 (8th Cir.), cert. denied, 419 U.S. 836 (1974).

73 Harold Friedman, Inc. v. Kroger Co., 581 F.2d 1068 (3d Cir. 1978).

74 Coca-Cola Co. v. Howard Johnson Co., 386 F. Supp. 330 (N.D. Ga. 1974).

75 Hiland Dairy, Inc. v. Kroger Co., 402 F.2d 968 (8th Cir. 1968), cert. denied, 395 U.S. 961 (1969); Photovest Corp. v. Fotomat Corp., 1977-1 Trade Cas. I 61,529 (S.D. Ind. 1977), aff'd in part and reo'd in part, 606 F.2d 704 (7th Cir. 1979), cert. denied, $100 \mathrm{~S}$. Ct. 1278 (1980); Pecora Oil Co. v. Shell Oil Co., 1975-1 Trade Cas. \60,156 (N.D. Ill. 1975).

${ }^{76}$ Structure Probe, Inc. v. Franklin Inst., 450 F. Supp. 1272 (E.D. Pa. 1978), aff'd, 595 F.2d 1214 (3d Cir. 1979); Bergjans Farm Dairy Co. v. Sanitary Milk Prods., 241 F. Supp. 476 (E.D. Mo. 1965), aff'd, 368 F.2d 679 (8th Cir. 1966). 
hardly warrants the Commission's description of "predatory" or "vicious" anticompetitive behavior. In virtually no cases have plaintiffs been denied relief where significant power in a properly defined relevant market, specific intent and predatory conduct were all established. Overwhelmingly, the cases decided for defendants have been dismissed not because the standards of legality have been unduly strict, but because in most instances there has not been even a minimal showing of a section 2 violation. The results would be the same in these suits whether the Holmes test or the Commission's proposed legislation were applied. United States $v$. Empire Gas Corp., ${ }^{77}$ which the Commission regards as illustrative of the shortcomings in existing law, provides a tenuous example at best. The case is analyzed below.

\section{B. The Empire Gas Decision}

The Commission regards the Eighth Circuit's decision in United States v. Empire Gas Corp. ${ }^{78}$ as incorrect and as demonstrating the mischief being worked by the dangerous probability requirement. It is very doubtful, however, that the court which was unable to find a dangerous probability of success in that case would have been any more inclined to find a "dangerous risk." Nevertheless, even if Empire Gas were wrongly decided, which is by no means clear, one exception does not justify revision of an entire body of law which has been coherently applied in scores of other decisions, the outcomes of which are unquestioned. ${ }^{79}$

In Empire Gas the Government charged an attempt to monopolize the market for liquefied petroleum gas in two localities in Missouri. Allegedly, defendant had threatened to destroy the business and property of its competitors, engaged in price fixing and reciprocal dealing, and obtained covenants not to compete from its employees and others. ${ }^{80}$ Although all but the last of these allegations were abandoned on appeal as separate violations, ${ }^{81}$ the Government continued to rely on evidence of defendant's pricing practices as evidence of specific intent to monopolize. ${ }^{82}$

77537 F.2d 296 (8th Cir. 1976), cert. denied, 429 U.S. 1122 (1977).

78537 F.2d 296 (8th Cir. 1976), cert. denied, 429 U.S. 1122 (1977).

79 See REPort, supra note 2, at 353 (separate views of Commissioner Hatch), 384 (separate views of Commissioner Izard), 403-04 (separate views of Commissioner McClory).

$80537 \mathrm{F.2d}$ at 298 n.1. In a separate criminal trial, Empire Gas Corporation, its president and the president of two private security firms were also charged with destroying property of Empire's competitors. All were acquitted by a jury.

81 Id. 298.

82 Id. 299. 
The Government's method of selecting the putative local markets and of measuring defendant's power in them was ridiculed by both the district court and the court of appeals. The Government's proof of relevant "local marketing areas" consisted of road maps on which ambiguous boundary lines had been drawn, apparently by one of the Government attorneys. The district judge remarked: "No credible evidence was adduced to establish the methodology or underlying data used in drawing these lines. Indeed, the Court still does not know how, why, and by whom the lines were drawn." 83 The court of appeals echoed this complaint: "No reasons were given for acceptance or rejection of any of the areas, nor were the criteria used in selecting areas entered into evidence, despite repeated requests therefor by the judge." 84

The court of appeals was skeptical of the proffered market, pointing out that " $[\mathrm{t}]$ he sales area of a defendant is not necessarily the same as the relevant geographic market for antitrust analysis," 85 and noting that sellers of the relevant product customarily operated in areas much larger than the size of the market the Government alleged. The court observed that it had "misgivings about the Government's method, or lack of method" 86 and might not accept its market designations in another case, but it would accept them. for purposes of this appeal only because it was plain that there had been a failure of proof of dangerous probability of success.

In an effort to establish defendant's market power, the Government had introduced a survey which purported to show that defendant possessed a fifty percent share of the market in one of the localities and a forty-seven percent share in the other. The district judge took the Government to task for failing to follow the court's pre-announced procedure of submitting questionnaires underlying any survey to the defendant and to the court in advance of their distribution so that questions of adequacy and admissibility could be decided prior to their use. ${ }^{57}$ The trial judge also pointed out that the Government's principal witness for establishing a foundation for the survey disclaimed any qualification as an economist and testified that his function had been equivalent to that of a bookkeeper. ${ }^{88}$ The court of appeals noted further:

83 United States v. Empire Gas Corp., 393 F. Supp. 903, 906 (W.D. Mo. 1975), affd, 537 F.2d 296 (8th Cir. 1976), cert. denied, 429 U.S. 1122 (1977).

84537 F.2d at 304 .

$85 I d$.

S6 Id. 305.

87393 F. Supp. at 909-10.

88 Id. 910. 
We agree with the district court that the survey's reliability was extremely doubtful. The questionnaire upon which it was based did not specify any records that should be used in submitting responses and the government's witness did not know what records were used. One of the government's witnesses who responded to the questionnaire testified that the figures he submitted came "off the top of my head." The government made no real attempt to verify any of the figures in the responses. Data were collected for only one year, 1972.89

The court of appeals went on to say that even accepting the fifty and forty-seven percent market shares, these figures alone were not sufficient to establish a dangerous probability of success. ${ }^{00}$ Although the Government adduced evidence of harmful conduct in various parts of Missouri, the court found nothing in the record to indicate that competitors in the two localities at issue had been intimidated by the defendant. The court found insufficient proof that defendant's competitors raised or fixed prices, stopped soliciting defendant's customers, or gave up any business as a result of defendant's activities. ${ }^{91}$

The court of appeals also chastised the Government's expert economists who testified as to dangerous probability. Specifically, the court found that the experts' price comparisons, which were prepared to show defendant's market power, had been calculated erroneously.92 When the court recalculated the figures the results were markedly different and did not indicate the necessary power.

The court concluded that, taking the evidence as a whole, it could not find the requisite proof of dangerous probability of success:

The government established that: (a) Empire had a large share of the market in Lebanon and Wheaton [the two localities] in 1972: about 50\%; (b) it has engaged in anticompetitive conduct in various areas, which has not been shown to have been effective in the Lebanon or Wheaton areas; (c) the price of LP in Lebanon may be slightly higher than in some other areas, but the reasons for this

80537 F.2d at 305 (footnote and citation omitted).

$90 \mathrm{Id}$.

91 Id.

92 The expert attempted to compare prices in the subject localities with prices in surrounding areas. He averaged the prices charged in each area to arrive at an "average price" but paid no attention to how much volume had been sold at each price or how long each price had been in effect. See id. 306. 
are a matter of speculation; (d) the defendant has had a fairly high rate of profit for the past ten years. We cannot conclude from this inconclusive evidence that there is a dangerous probability that the defendant will be able to monopolize the LP gas business, or exert control over prices or competition in the Lebanon or the Wheaton market areas. Therefore, we hold that the district court was not clearly erroneous when it found that the government failed to prove dangerous probability of success in its attempt to control competition or its attempt to raise prices by price intimidation. ${ }^{93}$

The Government filed a petition for certiorari, arguing that proof of a dangerous probability of success should not be required to support a charge of attempted monopolization. ${ }^{94}$ Defendant replied by pointing out that a bill had been introduced in the Senate in 1974 which included a provision specifically designed to eliminate the dangerous probability requirement, but that after a year in committee this provision had been stricken. ${ }^{55}$ If this already were the law, defendant argued, there would have been no need for such a bill. Defendant also pointed out that the Supreme Court had required establishment of a relevant market in Walker Process Equipment, Inc. v. Ford Machinery and Chemical Corp., ${ }^{96}$ and that the dangerous probability requirement previously had been upheld in every circuit but the Ninth. ${ }^{97}$ Certiorari was denied.

93 Id. 307 (citation omitted).

94 The Government relied on the Ninth Circuit's decision in Lessig v. Tidewater Oil Co., 327 F.2d 459 (9th Cir.), cert. denied, 377 U.S. 993 (1964). See text accompanying notes 105-17 infra.

95 Respondent's Brief at 8 . The bill was S. 1284, 94th Cong., 1st Sess. $\$ 704$ (1975). It has added a sentence to section 2 of the Sherman Act providing that in attempt- or conspiracy-to-monopolize cases "proof of a relevant market or a dangerous probability of success ... shall not be required." See 121 Cong. REc. 13,182 (1975) (remarks of Sen. Bayh); Kintner \& Goldston, Section 2 of the Sherman Act: The Attempt to Monopolize Offense, 24 N.Y.L. Scm. L. REv. 577, 578 n.6 (1979).

96382 U.S. 172, 177 (1965).

97 Addressing the Ninth Circuit, defendant argued that Lessig v. Tidewater Oil Co., 327 F.2d 459 (9th Cir.), cert. denied, 377 U.S. 993 (1964), see text accompanying notes 105-17 infra, (1) was decided before Walker Process; (2) was dictum; (3) was limited to its facts by the court on rehearing; and (4) failed to distinguish between attempt and conspiracy cases under section 2. Respondent's Brief at 12.

Defendant also argued that the Seventh Circuit's decision in Kearney \& Trecker Corp. v. Giddings \& Lewis, Inc. 452 F.2d 579 (7th Cir. 1971), cert. denied, 405 U.S. 1066 (1972), which, like Lessig, was relied on by the Government, clearly applied the dangerous probability test and had been repeatedly cited as rejecting Lessig. Repsondent's Brief at 14-15. Kearney \& Trecker is discussed at text accompanying notes $149-59$ infra. 
The Commission seems to read Empire Gas as holding that the coercion of competitors into maintaining prices at a level desired by the defendant, coupled with a specific intent to monopolize, is plainly lawful if defendant's share of a properly defined market ${ }^{88}$ is not at the brink of monopoly. The Commission ignores the fact that the court had serious misgivings about the Government's definition of the geographic market, ${ }^{99}$ which it nonetheless accepted for purposes of the appeal, and that its decision on the dangerous probability issue was based upon the inadequacy of the Government's proofs. ${ }^{100}$ The record showed that there were many competitors in the geographic market, that new ones were appearing frequently, and that the barriers to entry were minimal. ${ }^{101}$ The court concluded that the Government's estimate of defendant's market share was extremely doubtful, the Government's statistical survey was fatally deficient, and the testimony of the Government's economic expert was infected with numerous errors requiring its rejection. ${ }^{102}$ The court's ruling was thus based not merely on the insufficiency of the defendant's market share-as the Commission suggests-but on many factors that the Commission itself believes should be taken into account in passing upon the issue of dangerous probability.

It is also worth emphasizing that Empire Gas was a civil suit brought by the United States. No legislative revision is necessary to enable the Government to eliminate significantly anticompetitive activities through the Federal Trade Commission under its broad mandate to prohibit single-actor anticompetitive conduct. ${ }^{103}$ One can only conclude that Empire Gas was brought by the wrong agency in the wrong forum, with an ineptitude of trial preparation, warranting trenchant criticism of the prosecution rather than an attack upon the judiciary and a demand for a change of law. ${ }^{104}$

98 RePont, supra note 2, at 145-49.

99 Id. $146-47$.

100 Id.

101537 F.2d at 305.

102 Id. 306-07.

103 I5 U.S.C. $\$ 45$ (1976).

104 Thomas E. Kauper, former Assistant Attorney General in charge of the Antitrust Division, recently remarked that had he known that Empire Gas would produce the proposal drafted by the Commission he never would have authorized the filing of the complaint. [1979] 928 Antrmest \& Trade Reg. Rep. (BNA) A-23.

Another former head of the Antitrust Division, Donald I. Baker, has defended the Government's suit as an attempt to reach single-firm predatory behavior undertaken for the purpose of achieving a comfortable market position short of monopoly power. On the other hand, he warned that opening up the attempted monopolization offense "indiscriminately" could lead to the use of attempt cases themselves as 


\section{Lessig and Subsequent Ninth Gircuit Decisions}

Dissatisfied with the outcome in Empire Gas, the proponents of the new legislation have moved at least some distance along the trail blazed by the Ninth Circuit in Lessig v. Tidewater Oil Co., ${ }^{105}$ which dispensed with the dangerous probability requirement entirely. It is therefore appropriate to examine the experience of the Ninth Circuit in recent attempt cases. Lessig marks the outer limit of efforts to eliminate considerations of market structure from the law of attempted monopolization, but it represents only one of three lines of authority that have developed in the Ninth Circuit. Most of the panels there have either refused to follow Lessig or have adopted a hybrid position between the extremes of insisting upon or totally eliminating proof of dangerous probability. In the overwhelming majority of Ninth Circuit decisions, defendants have prevailed even under Lessig or the intermediate rule, ${ }^{106}$ which is strong evidence that most attempt cases founder not because of the strict application of present standards of liability, but because of deficiencies in the plaintiff's proofs.

The court in Lessig rejected application of the traditional Holmes approach and held that neither relevant market nor dangerous probability of success are necessary elements in an attempt case, defendant's specific intent to monopolize being the sole essential issue. The plaintiff, a service station operator, charged that the defendant, an oil company, had engaged in resale price maintenance and had imposed exclusive dealing and tying contracts upon its dealers in connection with purchases of tires, batteries and accessories (TBA). It was alleged that this conduct violated sections 1 and 2 of the Sherman Act as well as section 3 of the Clayton Act.

The court of appeals, reversing the trial judge's withdrawal of the attempted monopolization charge from the jury, "reject[ed] the premise that probability of actual monopolization is an essential element of proof of attempt to monopolize." 107 Indeed, the court went on to say that "the relevant market is 'not in issue" " 108 in an

devices to forestall new competition. See Remarks of Donald I. Baker before the President's Commission, reprinted in 48 ANTrTaust L.J. 831 (1980).

105327 F.2d 459 (9th Cir.), cert. denied, 377 U.S. 993 (1964).

108 See note 131 infra.

107327 F.2d at 474 (footnote omitted).

108 Id. (quoting United States v. E. I. DuPont de Nemours \& Co., 351 U.S. $377,395 \mathrm{n} .23$ (1956)). In DuPont, however, the Supreme Court said only that the relevant market was not in issue in two cases cited by the Government because the charge in those cases was conspiracy to monopolize rather than attempt to monopolize. See Becker v. Safelite Glass Corp., 244 F. Supp. 625, 637 (D. Kan. 1965) (distinguishing the DuPont footnote). 
attempted monopolization case. The court held that because section 2 prohibits attempts to monopolize "any part" of commerce, it would suffice to show that a firm attempted to monopolize any "appreciable segment" of commerce, including that segment consisting solely of sales of gasoline by that firm's licensed dealers and purchases by those dealers of TBA. ${ }^{109}$ The court theorized that if "monopoly" means the power to control prices or exclude competitors, ${ }^{110}$ then defendant's power to control the resale prices of its licensed dealers constituted monopoly, as did defendant's power to exclude its competitors from selling TBA to those same dealers.

The Ninth Circuit's reasoning fails to recognize that the Supreme Court's definition of monopoly as the power to control prices or exclude competition refers to the power to control market prices ${ }^{111}$ or exclude competition in the market, which in the case of gasoline retailing consists of a multiplicity of competing brands. ${ }^{112}$ In Lessig the court narrowed the market to the seller's own trademarked product, contrary to the teaching of scores of other cases. ${ }^{113}$ Having done so, the only remaining issue was the seller's intent, and that could hardly have been the subject of controversy. ${ }^{114}$

If the power to control prices in, or exclude competitors from, literally "any" part of commerce would suffice to prove monopoly, every exclusive dealing contract-perhaps every contract-would constitute monopolization because it would exclude competitors from that part of commerce encompassed by such an arrangement. ${ }^{115}$ Defendant made this point in its petition for rehearing, and although the court denied the petition, it was prompted to add the enigmatic qualification that the section of its original opinion dealing with attempted monopolization must "be read with the remainder, and in

109327 F.2d at 474-75. (1956).

110 See United States v. E.I. DuPont deNemours \& Co., 351 U.S. 377, 391

111 See United States v. Grinnell Corp., 384 U.S. 563, 571, 576 (1966).

112 See United States v. E.I. DuPont de Nemours \& Co., 351 U.S. 377, 391 (1956); Edward J. Sweeney \& Sons v. Texaco, Inc., 1980-1 Trade Cas. I 63,611, at 77,235-36 (3d Cir. 1980); Mullis v. Arco Petroleum Corp., 502 F.2d 290, 296-97 (7th Cir. 1974).

113 See note 44 supra.

114 Lessig has also been roundly criticized for failing to distinguish between the standards applicable to attempt-to-monopolize and conspiracy-to-monopolize cases. See, e.g., Hibner, supra note 25, at 175-77. See also note 108 supra. The probability of success is not a critical question when a conspiracy to achieve monopoly, together with an overt act designed to accomplish that end, are proved.

115 See Blecher, supra note 26, at 217; Note, Attempt to Monopolize Under the Sherman Act: Defendant's Market Power as a Requisite to a Prima Facie Case, 73 Colum. L. Rev. 1451, 1467 (1973). 
light of the anticompetitive purposes and conduct to which the case relates." 116

In effect, the Lessig court transplanted the now-discarded concept of "quantitative substantiality" from the law of exclusive dealing into the law of attempted monopolization. It held that the termination of a single dealer in circumstances where section 1 itself is not violated-there being neither conspiracy nor unreasonable restraint of trade-may nevertheless constitute an infraction of section 2. It is interesting to note that the Lessig case included allegations of exclusive dealing, and that Lessig was one of the last cases to cling to the doctrine of quantitative substantiality in applying section 3 of the Clayton Act. ${ }^{117}$

Subsequent to Lessig, Ninth Circuit panels have adopted three distinct approaches to the attempt offense. Some panels have adhered to the traditional approach, insisting that plaintiffs delineate the relevant market and establish defendants' dangerous probability of success.118 Some panels have followed Lessig and abjured the coordinate requirements of dangerous probability and market definition.119 More recently, other panels have adopted a hybrid approach, essentially combining elements of the Lessig rationale and the traditional rubric in a formulation which, although basically resembling that suggested by the Commission, is occasionally more reminiscent of the traditional model. ${ }^{120}$

$110327 \mathrm{~F} .2 \mathrm{~d}$ at 478 . This limitation may help to explain the willingness of other Ninth Circuit panels to depart from the Lessig approach. See text accompanying notes 118-20 infra.

117 The court relied on Standard Oil Co. v. United States, 337 U.S. 293 (1949), and other cases decided before the Supreme Court's decision in Tampa Elec. Co. v. Nashville Coal Co., 365 U.S. 320 (1961), which it cited only in passing. 327 F.2d at 468-70. See generally $1 \mathrm{M}$. HandiER, TwentY-Frve Years of ANTITRUST 408-17 (1973).

118 See, e.g., ALW, Inc. v. United Air Lines, Inc., 510 F.2d 52, 57 (Oth Cir. 1975); Cornwell Quality Tools Co. v. C.T.S. Co., 446 F.2d 825, 832 (9th Cir. 1971), cert. denied, 404 U.S. 1049 (1972); Jerrold Elec. Corp. v. Wescoast Broadcasting Co., 341 F.2d 653, 664 (9th Cir.), cert. denied, 382 U.S. 817 (1965); Wisdom Rubber Indus., Inc. v. Johns-Manville Sales Corp., 415 F. Supp. 363, 367-68 (D. Hawaii 1976).

119 See, e.g., Greyhound Computer Corp. v. IBM, 559 F.2d 488, 504 (9th Cir. 1977), cert. denied, 434 U.S. 1040 (1978); Knutson v. Daily Review, Inc., 548 F.2d 795, 813-14 (9th Cir. 1976), cert. denied, 433 U.S. 910 (1977); Industrial Bldg. Materials, Inc. v. Interchemical Corp., 437 F.2d 1336, 1344 (9th Cir. 1970).

120 See, e.g., Hunt-Wesson Foods, Inc. v. Ragu Foods, Inc., 627 F.2d 919 (9th Cir. 1980); Blair Foods, Inc. v. Ranchers Cotton Oil, 610 F.2d 665 (9th Cir. 1980); California Computer Prods., Inc. v. IBM, 613 F.2d 727 (9th Cir. 1979); Gough v. Rossmoor Corp., 585 F.2d 381 (9th Cir. 1978), cert. denied, 440 U.S. 936 (1979); Marquis v. Chrysler Corp., 577 F.2d 624 (9th Cir. 1978); Janich Bros. v. American Distilling Co., 570 F.2d 848 (Oth Cir. 1977), cert. denied, 439 U.S. 829 (1978). 
In ALW, Inc. $v$. United Air Lines, Inc., ${ }^{121}$ decided under the traditional standard, plaintiff asserted a claim which the court recognized might constitute breach of contract or fraudulent misrepresentation, but which had been advanced primarily under sections 1 and 2 of the Sherman Act. Plaintiff, the operator of a resort in Nevada, charged that defendant airline had promised to feature its resort in an article to be published in a magazine regularly distributed free of charge to defendant's passengers. Plaintiff cooperated with this effort and, in anticipation of the expected publicity, refrained from placing any paid advertising in the issue of defendant's magazine in which the feature was scheduled to appear. Defendant changed course, however, and did not mention plaintiff's hotel in the article, allegedly because of pressure from other resort operators and because defendant's parent company was considering construction of its own hotels in the area.

Plaintiff charged that because defendant operated the only direct scheduled flights between the Reno-Lake Tahoe area and the eastern United States, its complimentary magazine constituted a monopoly in the "market for public relations and advertising addressed to travelers and potential air travelers" from the East Coast to Reno-Lake Tahoe. The court held that this putative market was drawn too narrowly because defendant's aircraft carried numerous publications in addition to its own magazine, and all of these media competed for advertising dollars and for the passenger's attention. The court emphasized that a single supplier's product cannot constitute a separate market unless it is so unique or so dominant that any action by the supplier to increase his control over the market will virtually assure the destruction of competition. ${ }^{122}$ The court held that plaintiff had failed to establish that defendant possessed the power to control prices or exclude competition in the relevant market even if that market were limited to publications carried on defendant's aircraft, and this precluded any inference of dangerous probability of success. The court also found that there had been no intent to monopolize. ${ }^{123}$

In Janich Bros. v. American Distilling Co., ${ }^{124}$ which exemplifies the third, or hybrid approach, the court recognized that the plaintiff must prove three elements in order to establish a prima facie case of attempted monopolization: (1) defendant's specific intent to

121510 F.2d 52 (9th Cir. 1975).

122 See note 44 supra.

123510 F.2d at 52.

124570 F.2d 848 (9th Cir. 1977), cert. denied, 439 U.S. 829 (1978). 
control prices or restrict competition in a part of interstate commerce; (2) predatory conduct aimed at achieving that wrongful objective; and (3) the dangerous probability that defendant will succeed in monopolizing that part of commerce. The court, striking a compromise between Lessig and the traditional approaches, held that the third requisite element, dangerous probability, can be satisfied either by direct proof of defendant's market power or by inferring dangerous probability from proof of defendant's specific intent to control prices or restrict competition in a part of the market. Specific intent may in turn be inferred from predatory conduct undertaken by defendant so long as that conduct is a basis for a substantial claim of restraint of trade. As the court explained, "[w] $w$ here a plaintiff relies only upon a defendant's conduct to establish an attempted monopolization claim and does not show market power, specific intent to monopolize should ordinarily be inferred only where the alleged conduct is of a kind clearly threatening to competition or clearly exclusionary." 125 Most recent Ninth Circuit cases have adopted this hybrid approach. ${ }^{126}$

In Janich, both plaintiff and defendant were suppliers of alcoholic beverages. Plaintiff charged defendant with attempted monopolization and price discrimination on the ground that it had sold private-label gin and vodka at lower prices in California than in the rest of the United States. Although the court held that dangerous probability could be inferred from specific intent and that specific intent could be inferred from predatory conduct, it went on to find that the conduct charged had not been established because plaintiff failed to prove that defendant had sold below its average variable cost. ${ }^{127}$ The court also rejected as hearsay plaintiff's direct evidence of specific intent consisting of an alleged statement by one of defendant's employees to the effect that defendant planned to lower its prices in California in order to run its competitors out of business and then increase its prices.

The case was disposed of on its facts, but its approach is significant because the retained requirement of dangerous probability can be inferred either from defendant's intent, conduct or market power. When inferred from market power, the dangerous probability requirement is vintage Holmes, or what he termed "a question of proximity and degree." 128 If inferred from intent or con-

125 Id. 854 n.4.

126 See note 120 supra.

127570 F.2d at 848 . The court relied on the Areeda-Turner test for predatory pricing. See note 65 supra \& accompanying text.

128 See text accompanying note 25 supra. 
duct, dangerous probability in effect is conclusively presumedin other words, dispensed with.

In practice, the hybrid rule has wrought more confusion than change. Inference of specific intent and dangerous probability from proof of predatory conduct has proven to be little more than a theoretical possibility, recognized by the courts at preliminary stages but almost never applied in a final judgment. Plaintiff after plaintiff has tried to convince courts in the Ninth Gircuit to draw the inference, but when dangerous probability could not be independently established with evidence of market power, the courts have consistently declined to hold that the conduct proved was sufficiently pernicious by itself to demonstrate dangerous probability. As one district court has observed, where there is no proof of market power to establish liability, the conduct alleged "must bear the full weight of that burden," 129 and pernicious anticompetitive behavior on the part of firms with no substantial market power is not easily demonstrated. ${ }^{130}$ The courts have been reluctant to hold that a plaintiff has met his ultimate burden of proving attempted monopolization without extrinsic proof of dangerous probability of success, and significantly, defendants have prevailed in virtually every case that has proceeded to judgment in the Ninth Circuit since Lessig. ${ }^{131}$

129 Pure Water Resources, Inc. v. Consolidated Foods Corp., 1980-1 Trade Cas. If 63,064, at 77,290 (N.D. Cal. 1979).

130 In Pure Water Resources, Inc. v. Consolidated Foods Corp., id., the court observed:

Where a plaintiff does not show market power, specific intent to monopolize should be inferred only where the alleged conduct has no legitimate business purpose; that is, conduct clearly threatening to competition, or clearly exclusionary. . . . As one commentator has noted, "[C]onduct may be ambigous unless examined in its structural setting. It may be honestly industrial, when engaged in by the firm without power, yet exclusionary where engaged in by the firm at or near monopoly levels of power." L. Sullivan, Antitrust 139 (1977).

Id., at 77,289-90 (citation omitted).

131 Blair Foods, Inc. v. Ranchers Cotton Oil, 610 F.2d 665 (9th Cir. 1980) (summary judgment for defendants affirmed); Cowley v. Braden Indus., Inc., 613 F.2d 751 (9th Cir. 1980) (judgment for defendant after bench trial affirmed); California Computer Prods., Inc. v. IBM, 613 F.2d 727 (9th Cir. 1979) (directed verdict for defendant affirmed); Naify v. McClatchy Newspapers, 599 F.2d 335 (9th Cir. 1979) (directed verdict for defendants affirmed); Marquis v. Chrysler Corp., 577 F.2d 624 (9th Cir. 1978) (directed verdict for defendant affirmed); Janich Bros. v. American Distilling Co., 570 F.2d 848 (9th Cir. 1977) (directed verdict for defendant affirmed), cert. denied, 439 U.S. 829 (1978); Brown v. Hansen Publs., Inc., 556 F.2d 969 (9th Cir. 1977) (judgment for defendant after bench trial affirmed); Mutual Fund Investors, Inc. v. Putnam Mgt. Co., 553 F.2d 620 (9th Cir. 1977) (summary judgment for defendant affirmed); Moore v. Jas. H. Matthews \& Co., 550 F.2d 1207 (9th Cir. 1977) (judgment for defendant after bench trial affirmed); Hanson v. Shell Oil Co., 541 F.2d 1352 (9th Cir. 1976) (directed verdict for defendant affirmed), cert. denied, 429 U.S. 1074 (1977); ALW 
The prominent role that dangerous probability continues to play under the hybrid approach was underscored in General Communications Engineering, Inc. v. Motorola Communications and Electronics, Inc., ${ }^{132}$ in which a district court struggled to reconcile the various holdings of the Ninth Circuit. The court settled on the hybrid rule, observing that dangerous probability could be established by either proof of a "significant amount of market power or by proof of a substantial restraint of trade." 133 Plaintiff charged that Motorola had attempted to monopolize the private two-way radio market in California and throughout the United States by engaging in such allegedly unfair practices as contacting plaintiff's

Inc. v. United Air Lines, Inc., 510 F.2d 52 (9th Cir. 1975) (summary judgment for defendant affirmed); Trixler Brokerage Co. v. Ralston Purina Co., 505 F.2 1045 (9th Cir. 1974) (judgment for defendant after bench trial affirmed); Chisholm Bros. Farm Equip. Co. v. International Harvester Co., 498 F.2d 1137 (9th Cir.) (directed verdict for defendant affirmed), cert. denied, 419 U.S. 1023 (1974); Hallmark Indus. v. Reynolds Metals Co., 489 F.2d 8 (9th Cir. 1973) (directed verdict for defendant affirmed), cert. denied, 417 U.S. 932 (1974); Bushie v. Stenocord Corp., 460 F.2d 116 (9th Cir. 1972) (summary judgment for defendant affirmed); Dahl, Inc. v. Roy Cooper Co., 448 F.2d 17 (9th Cir. 1971) (summary judgment for defendants affirmed); General Business Sys. v. North Am. Philips Corp., 1980-1 Trade Cas. $\int 63,607$ (N.D. Cal. 1980) (summary judgment for defendant granted); Fast Food Fabricators v. McDonald's Corp., 1980-2 Trade Cas. โ 63,552 (N.D. Cal. 1980) (summary judgment for defendant granted); Filmamatic Corp. v. General Electric Co., 1980-2 Trade Cas. $\int 63,417$ (N.D. Cal. 1980) (summary judgment for defendant granted); Robert's Waikiki U-Drive, Inc. v. Budget Rent-A.Car Sys., Inc., 491 F. Supp. 1199 (D. Hawaii 1980) (summary judgment for defendant granted); Determined Prods., Inc. v. R. Dakin \& Co., 1980-1 Trade Cas. If 63,063 (N.D. Cal. 1979) (summary judgment for defendant granted); Pure Water Resources, Inc. v. Consolidated Foods, Corp., 1980-1 Trade Cas. I 63,064 (N.D. Cal. 1979) (summary judgment for defendant granted); Foremost Int'l Tours, Inc. v. Qantas Airways Ltd., 478 F. Supp. 589 (D. Hawaii 1979) (judgment for defendant after bench trial); In re Western Liquid Asphalt, 478 F. Supp. 785 (N.D. Cal. 1979) (summary judgment for defendant granted); California Steel \& Tube v. Kaiser Steel Corp., 469 F. Supp. 265 (C.D. Cal. 1979) summary judgment for defendant granted); General Comm's Eng'r, Inc. v. Motorola Comm's \& Elec., Inc., 421 F. Supp. 274 (N.D. Cal. 1976) (summary judgment for defendant granted); Wisdom Rubber Indus. v. Johns-Manville Sales Corp., 415 F. Supp. 363 (D. Hawaii 1976) (summary judgment for defendant granted). But see Pacific Coast Agr. Export Ass'n v. Sunkist Growers, Inc., 526 F.2d 1196 (9th Cir. 1975) (jury verdict for plaintiff affirmed on the ground that dangerous probability of success could be inferred from proof of specific intent plus proof of monopoly power, but defendants were held liable not only for attempted monopolization, but actual monopolization and conspiracy to monopolize as well-of course, a holding of actual monopolization moots the issue of dangerous probability), cert. denied, 425 U.S. 959 (1976); Jack Winter Inc. v. Koratron Co., 375 F. Supp. 1, 69-71 (N.D. Cal. 1974) (specific intent and dangerous probability could be inferred from conduct where defendant controlled both an important patent and a trademark). Cf. Jerrold Elecs. Corp. v. Wescoast Broadcasting Co., 341 F.2d 653 (9th Cir.) (jury verdict for plaintiff affirmed; no discussion of Lessig), cert. denied, 382 U.S. 817 (1965).

132421 F. Supp. 274 (N.D. Cal. 1976).

133 Id. 286. 
customers and potential customers and disparaging plaintiff's equipment in order to induce them to do business with Motorola. The court held that because neither a specific intent to monopolize nor a dangerous probability of success was present, the plaintiff could not prevail. The court reasoned that the practices allegedly undertaken by Motorola had the appearance of the legitimate and normal manner in which competing firms behave-namely, imparting to potential customers product and service comparisons between their own products and the products of a competitor, thereby actively soliciting new customers by demonstrating the advantages of their own products. As a consequence, the requisite specific intent to monopolize could not be inferred from Motorola's conduct. Regarding the dangerous probability requirement, the court held that even accepting plaintiff's contention that Motorola enjoyed a sixtyfour to seventy-one percent share of the relevant market, competition in the two-way radio market was so intense that the danger of Motorola attaining monopoly power was minimal.

[I]n stark contrast to plaintiff's assertion that the ... market is uncompetitive and dominated by defendant, it appears that it is the purchasers ... who have the power. While Motorola may have a large market share today, it is apparent from the competitive nature of the industry that if it attempted to raise prices or reduce the quality of its equipment or service, its market share would rapidly diminish. ${ }^{134}$

The court granted summary judgment for the defendant.

More recently, in Blair Foods, Inc. $v$. Ranchers Cotton Oil, ${ }^{135}$ the Ninth Circuit purported to apply the hybrid rule, but permitted market share evidence to loom very large in the ultimate determination. The plaintiff in Blair was a processor and distributor of vegetable oil and had been founded by former employees of defendant Glen-Webb, a competitor. Allegedly, Glen-Webb had attempted to monopolize the market for vegetable oil by offering to undercut plaintiff's prices, making threats and statements predicting plaintiff's demise, stealing plaintiff's oil drums, and filing a lawsuit against plaintiff in state court. Glen-Webb also allegedly conspired with defendant Ranchers, a supplier of both Glen-Webb and the plaintiff, to cancel plaintiff's credit.

134 Id. 293.

135610 F.2d 665 (9th Cir. 1980). This case is discussed in Robert's Waikiki U-Drive, Inc. v. Budget Rent-A-Car Systems, Inc., 491 F. Supp. 1199, 1217-18 n.15 (D. Hawaii 1980). 
On defendant's motion for summary judgment, both the conspiracy claim and the attempted monopolization claim were dismissed for lack of proof. The district court found that the relevant market was "highly competitive" and that Glen-Webb had no power to either control prices or exclude competitors, even though it may have exhibited hostility toward plaintiff and its former employees who worked for plaintiff. 138

On appeal, plaintiff complained that the district court had placed undue emphasis on Glen-Webb's relative size, and contended that under Lessig this consideration was not relevant. ${ }^{137}$ Affirming, the Ninth Circuit rejected plaintiff's argument, explaining that under the hybrid rule, "[w] hile not indispensable, evidence of market power is relevant . . . and may suggest the existence of specific intent to monopolize." 138 As the court held:

The real issue in this type of case is one of specific intent to monopolize, and we find nothing in Lessig which excludes consideration of market power as one of the circumstances to be considered in determining whether such intent exists. Thus, discussion of market power by the trial court is proper in conjunction with a Section Two claim. ${ }^{139}$

The court interpreted the lower court's opinion as not resting entirely on the lack of market power because there was language "suggesting" that the evidence on predatory conduct was considered as well. ${ }^{140}$ Yet the court of appeals was clearly impressed with evidence in the record, not cited by the district court, that Glen-Webb held less than six percent of the market. ${ }^{141}$ Its holding appears to recognize that while proof of predatory conduct may give rise to an inference of specific intent under the hybrid test where there is no proof of market power, evidence of a lack of market power can establish an absence of specific intent and can thereby be determinative.

Thus, if dangerous probability is no longer an "essential" element under the hybrid rule, ${ }^{142}$ it nevertheless seems to have lost

136 Blair Foods, Inc. v. Ranchers Cotton Oil, 1977-2 Trade Cas. $\llbracket 61,576$, at 72,349 (N.D. Cal. 1977), affd, 610 F.2d 665 (9th Cir. 1980).

137610 F.2d at 669 .

$138 I d$.

139 Id. $669-70$.

140 Id. 670.

$141 \mathrm{Id}$. n.4.

142 Id. 670; see California Computer Prods., Inc. v. IBM, 613 F.2d 727 (9th Cir. 1979). 
little of its vigor. Although dangerous probability can be inferred from conduct, it is doubtful that the inference can withstand countervailing proof that defendant's market share is insubstantial. Blair suggests that market power has such a strong bearing on specific intent that when the evidence reveals substantial market power to be lacking, a finding of specific intent to achieve monopoly would be unrealistic. If proof of market power is no longer admitted through the front door under the hybrid rule, it apparently can enter readily through the back door. ${ }^{143}$

This is a constructive development. Unfortunately, however, by failing to explicitly recognize the necessity for proving dangerous probability, the hybrid rule continues to suffer from considerable ambiguity. Inconsistent decisions are likely to arise and wasteful litigation will be encouraged. A better approach is simply to recognize the need for an independent showing of dangerous probability, as some Ninth Circuit courts have continued to do. ${ }^{144}$ Implicit in this approach is the realization that low-market-share nuisance cases are likely to be instituted in increasing numbers if the dangerousprobability requirement is eliminated and intent made the sole criterion.

In Wisdom Rubber Industries v. Johns-Manville Sales Corp., ${ }^{145}$ for example, plaintiff sought to hold defendant liable for an attempt-to-monopolize violation despite the fact that plaintiff itself enjoyed an eighty percent share of the relevant market. Plaintiff had been a nonexclusive distributor of defendant's irrigation pipes in Hawaii, but was terminated after defendant decided to deal exclusively through another distributor. Plaintiff charged defendant, inter alia, with attempting to monopolize the irrigation pipe market in Hawaii. The record showed, however, that both before and after its termination by defendant, plaintiff accounted for eighty percent of sales in the relevant market. Contending that no actual power to monopolize had to be established, plaintiff argued that in the Ninth Circuit intent alone is at issue in an attempted monopolization case. The court disagreed, holding that "intent, without some probability of success, is mere wishful thinking and not the type of activity which the antitrust laws were designed to pro-

143 In Hunt-Wesson Foods, Inc. v. Ragu Foods, Inc., 627 F.2d 919, 925 (9th Cir. 1980), decided after Blair, another Ninth Circuit panel observed that where conduct is "clearly exclusionary," specific intent can be inferred under the hybrid rule regardless of market power. Because defendant's market share in that case was over 65 percent and rising, however, this was not the basis of the court's decision.

144 See note 118 supra.

148415 F. Supp. 363 (D. Hawaii 1976). 
tect. ... Moreover, impossibility in fact has always been a defense to a charge of attempted monopolization." 146

Experience teaches that Lessig and the hybrid rule which grew out of it have failed either to reduce delay or to enhance plaintiffs' chances for recovery. Perhaps the most significant difference between the Ninth Circuit and the rest of the federal courts is that plaintiffs in the Ninth Circuit continue to prosecute tenuous attempted-monopolization claims in dealer termination cases and the like, causing the courts to engage in circuitous inquiries before finally rejecting these claims. In some instances, courts have ruled against defendants on the basis of Lessig or the hybrid rule at a preliminary stage, only to dismiss the same attempted-monopolization charge after trial. ${ }^{147}$ Almost without exception, when courts have ruled in favor of plaintiffs in the Ninth Gircuit, it has been only to deny or reverse a summary determination and to require further proceedings. ${ }^{148}$ It is the ten other circuits that have expedited litigation, by refusing to entertain attempted monopolization claims when it is clear that no dangerous probability exists.

\section{Kearney \& Trecker}

The Commission embraces as its prototype for reform the Seventh Circuit's decision in Kearney \& Trecker Corp. v. Giddings

146 Id. 368 (citations omitted).

147 Compare, e.g., Foremost Int'l Tours, Inc. v. Qantas Airways, Ltd., 379 F. Supp. 88 (D. Hawaii 1974) (plaintiffs motion for preliminary injunction granted), aff'd, 525 F.2d 281 (9th Cir. 1975), cert. denied, 429 U.S. 816 (1976), with Foremost Int'l Tours, Inc. v. Qantas Airways, Ltd., 478 F. Supp. 589 (D. Hawaii 1979) (judgment for defendant granted after trial); Naify v. McClatchy Newspapers, 1977-1 Trade Cas. โ 61,383 (N.D. Cal. 1977) (defendants' motion for summary judgment denied), with Naify v. McClatchy Newspapers, 1977-2 Trade Cas. I 61,558 (N.D. Cal. 1977) (defendants' motion for directed verdict granted after trial), aff'd, 599 F.2d 335 (9th Cir. 1979).

148 See Hunt-Wesson Foods, Inc. v. Ragu Foods, Inc., 627 F.2d 919 (9th Cir. 1980) (grant of defendants motion to dismiss reversed); Ernest W. Hahn, Inc. v. Codding, 615 F.2d 830 (9th Cir. 1980) (grant of defendant's motion to dismiss reversed); Sherman v. British Leyland Motors, L.t., 601 F.2d 429 (9th Cir. 1979) (summary judgment for defendant reversed); Purex Corp. v. Procter \& Gamble Co., 596 F.2d 881 (9th Cir. 1979) (judgment for defendants after bench trial reversed); Greyhound Computer Corp. v. IBM, 559 F.2d 488 (9th Cir. 1977) (directed verdict for defendant reversed), cert. denied, 434 U.S. 1040 (1978); Moore v. Jas. H. Matthews \& Co., 473 F.2d 328 (9th Cir. 1973) (summary judgment for defendant reversed); Industrial Bldg. Materials, Inc. v. Interchemical Corp., 437 F.2d 1336 (9th Cir. 1971) (summary judgment for defendant reversed); Case-Swayne Co. v. Sunkist Growers, Inc., 369 F.2d 449 (9th Cir. 1966) (directed verdict for defendant reversed), cert. denied, 387 U.S. 932 (1967); Lessig v. Tidewater Oil Co., 327 F.2d 459 (9th Cir. 1964) (direct verdict for defendant reversed); Dobbins v. Kawasaki Motor Corp., 362 F. Supp. 54 (D. Ore. 1973) (defendant's motion for summary judgment denied). See also cases cited in note 131 supra. But see Pacific Coast Agr. Export Ass'n v. Sunkist Growers, Inc., 526 F.2d 1196 (9th Cir. 1975), cert. denied, 425 U.S. 959 (1976); Jack Winter Inc. v. Koratron Co., 375 F. Supp. I (N.D. Cal. 1974). 
of Lewis, Inc. ${ }^{149}$ The Commission implies that this case ushered in a new "balancing" standard for attempted monopolization, diluting the importance of dangerous probability as an element of the offense. ${ }^{150}$ In reality, the decision is consistent with the original Holmes formulation.

Kearney of Trecker featured some reprehensible conduct coupled with a genuinely dangerous probability of success. Plaintiff and defendant were competing manufacturers of automatic machine tools. Plaintiff sued defendant for patent infringement and defendant counterclaimed under section 2 of the Sherman Act, charging that plaintiff's patent had been improperly issued and was being used in an attempt to achieve monopoly power. The evidence showed that immediately after signing plaintiff's original patent, the primary examiner assigned to the matter retired from the Patent Office and became a paid consultant for plaintiff, assisting plaintiff in securing two reissues of the same patent. The patent was of strategic importance to the industry and very broad in its coverage, which virtually coincided with the relevant market. The court held that plaintiff was chargeable with "deceptive intention" 151 in securing the reissues, and found against plaintiff both on its infringement claim and on defendant's section 2 counterclaim. The court held that plaintiff's improper retention of the patent examiner constituted predatory conduct and that its patent claims and other circumstances revealed an intent to exclude competition from a "broad" segment of the market, "endanger[ing] the competitive process." 152 It also found a dangerous probability of success on the grounds of plaintiff's size, plaintiff's ownership of the strategically important patent, and the fact that plaintiff was a licensor of at least one significant competitor.

The only gloss placed on the Holmes standard by Judge, now Justice, Stevens, writing for the court, was the observation that assessment of dangerous probability does not "involve an evaluation of the actual likelihood that an attempt would have succeeded if not frustrated by an intervening event." 153 Instead, but still consistent with Holmes, Judge Stevens wrote that this evaluation

requires an appraisal of the alleged offender's ability to achieve the forbidden result, his intent, and the nature of

149452 F.2d 579 (7th Cir. 1971), cert. denied, 405 U.S. 1066 (1972).

150 REPORT, supra note 2, at 147.

161 See 35 U.S.C. $\$ 251$ (1976).

$152452 \mathrm{~F} .2 \mathrm{~d}$ at 598 .

163 Id. 
his overt actions. In an antitrust context we must consider the firm's capacity to commit the offense, the scope of its objective, and the character of its conduct. The ultimate concern is the firm's actual or threatened impact on competition in the relevant market. ${ }^{154}$

The "ability to achieve the forbidden result" and "capacity to commit the offense" clearly refer to proof of market power. Kearney or Trecker differs from typical attempted monopolization cases only because the court's finding of a dangerous probability of success was based not solely on defendant's market share, but also on the fact that defendant possessed added market power by virtue of its ownership of a strategic patent. Although the Commission failed to mention it, it is significant that defendant's market share was thirty-three percent-far less than the "near monopoly share" which the Commission claims is often considered a "prerequisite" under the present standard. ${ }^{165}$ In monopolization, as in merger cases, market share is evidence of market power but is not conclusive. ${ }^{158}$ In the words of Judge Stevens, the decisive issue is whether the defendant is "a firm with the capacity to make a serious attempt to acquire monopoly status." 157 Kearney \& Trecker ushered in no new standard, but was simply an application of Holmes's dangerous probability test-which Judge Stevens not only relied upon but quoted ${ }^{158}$-to a somewhat atypical set of facts. ${ }^{159}$

154 Id. (emphasis added; footnotes omitted).

155 Rerort, supra note 2, at 146. Kearney \& Trecker is not unique in finding a dangerous probability with less than a 50 percent market share. See Kearney \& Trecker Corp. v. Cincinnati Milacron Inc., 562 F.2d 365, 373 (6th Cir. 1977); Outboard Marine Corp. v. Pezetel, 461 F. Supp. 384, 404 (D. Del. 1978) (35\% share stipulated to be sufficient); Lektro-Vend Corp. v. Vendo Co., 403 F. Supp. 527,534 (N.D. Ill. 1975) (20\% share sufficient where concentration increasing), aff'd, 545 F.2d 1050 (7th Cir. 1976), rev'd on other grounds, 433 U.S. 623 (1977).

156 See Byars v. Bluff City News Co., 609 F.2d 843, 850-55 (6th Cir. 1980); Oetiker v. Jurid Werke, G.m.b.H., 556 F.2d 1 (D.C. Cir. 1977); Note, Attempt to Monopolize Under the Sherman Act: Defendant's Market Power as a Requisite to a Prima Facie Case, 73 Colum. L. Rev. 1451, 1474 (1973). See also Cliff Food Stores, Inc. v. Kroger, Inc., 417 F.2d 203, 207 n.2 (5th Cir. 1969) ("one must be particularly wary of the numbers game of market percentages when considering an 'attempt to monopolize' suit"); Becker v. Safelite Glass Corp., 244 F. Supp. 625 (D. Kan. 1965). The same caution has been exercised in assessing market power under section 7 of the Clayton Act. See United States v. General Dynamics Corp., 415 U.S. 486 (1974).

$157452 \mathrm{~F} .2 \mathrm{~d}$ at 598 .

158 Id. n.44.

159 Kearney \& Trecker has been cited in a number of later cases as rejecting Lessig and maintaining the dangerous probability standard. E. J. Delaney Corp. v. Bonne Bell, Inc., 525 F.2d 296, 305 (10th Cir. 1975), cent. denied, 425 U.S. 906 (1976); Radzik v. Chicagoland Rec. Vehicle Dealers Ass'n, 1972 Trade Cas. I 74,167 (N.D. Ill. 1972); cf. Holleb \& Co. v. Produce Terminal Cold Storage Co., 532 F.2d 29, 33 ( 7 th Cir. 1976) (same, without specific reference to Lessig). 
This was confirmed three years later in Mullis $v$. ARCO Petroleum Corp. ${ }^{160}$ in which Judge Stevens applied the dangerous probability standard to reject an attempted monopolization charge against an oil company that had terminated one of its dealers during the 1973 oil shortage, but that controlled only three percent of the relevant market: "There is no evidence that its share is growing, and certainly no basis for inferring any dangerous probability that it would ever approach monopoly proportions." 161

The Commission expressed approval of Mullis as an example of the use of the dangerous probability standard as a check when a defendant's conduct is "competitively ambiguous" and may in fact constitute "legitimate competitive behavior." ${ }^{162}$ As noted earlier, the Commission would adopt a sliding scale test under which the more "unambiguously anticompetitive" the conduct involved, the less weight would be afforded the element of dangerous probability, and vice versa. ${ }^{163}$ But Judge Stevens never differentiated between the fact patterns in Mullis and Kearney o Trecker, nor did he purport to be affording different weight to the dangerous probability requirement in the two cases on the ground that the conduct in one case was more "competitively ambiguous" than in the other. Where, one might ask, would the Commission draw the line between "competitively ambiguous" and unambiguous behavior? Even Kearney \& Trecker drew a dissent despite its supposedly "unambiguous" nature, and Mullis reversed the district court, which apparently had discerned no ambiguity. Indeed, ambiguity can be expected to surface in virtually every case of single-

160502 F.2d 290 (7th Cir. 1974).

161 Id. 297 (emphasis added; footnote omitted). Plaintiff had been terminated after twenty years as a distributor of defendants' oil products. It canvassed twenty other suppliers but was unable to obtain a new source, the oil shortage having already materialized. Plaintiff contended that his termination during the shortage served to exclude him from the market totally, in violation of section 2.

162 REPORT, supra note 2 , at 148,170 n.26.

$163 \mathrm{Id}$. 147-49. The sliding scale test has also been proposed by a number of commentators. See Cooper, Attempts and Monopolization: A Mildly Expansionary Answer to the Prophylactic Riddle of Section Two, 72 Mrch. L. REv. 373, 401-03 (1974); Note, Attempt to Monopolize Under the Sherman Act: Defendant's Market Power as a Requisite to a Prima Facie Case, 73 Colum. L. Rev. 1451, 1473-75 (1973); Comment, The Attempt to Monopolize Charge: The Sherman Act's Atrophied Arm, 48 Miss L.J. 55, 83 (1977); Comment, 53 Tex. L. Rev. 551, 562-66 (1975). One commentator has remarked that definition of the relevant market has already achieved a sliding scale character of its own, with the scope of the market expanding or contracting "in direct proportion to the viciousness of the overt acts alleged." Hibner, supra note 25 , at 168 .

The sliding scale approach was criticized by Commissioner McClory, who remarked that it would "throw the business community into confusion and create the greatest uncertainty where the law should be clearest-when it serves to guide solitary conduct." REPORT, supra note 2 , at 403. 
actor conduct. Kearney \& Trecker did not purport to apply a stricter test to "unambiguous" behavior and cannot be read as embracing the sliding scale that the Commission favors.

\section{E. The Current Standards in Operation}

The Commission's report implies that the present attemptedmonopolization standards are not working and that malevolent single-firm conduct is going virtually unchecked. It is therefore worth examining more closely some of the recent cases that have maintained the dangerous probability requirement, in order to understand the role of this requirement in attempt litigation.

In a number of cases plaintiffs have sought to construct an attempt-to-monopolize violation in situations where, as the courts have recognized, monopoly was not realistically threatened. In Coca-Cola Co. v. Howard Johnson Co., ${ }^{164}$ for example, Coca-Cola brought suit against Howard Johnson for trademark infringement and unfair competition, and was met with an attempt-to-monopolize counterclaim. Howard Johnson claimed that Coca-Cola's advertising campaign touting Coke as the "Real Thing" was designed to persuade members of the public that any other cola-flavored beverage was inferior to Coke and was harmful to consumers. By adopting the "Real Thing" advertising campaign, Coca-Cola allegedly had attempted to monopolize the cola-flavored soft drink industry. In dismissing Howard Johnson's counterclaim, the court pointed to its failure to allege a dangerous probability of success:

If there is no reasonable probability that a defendant will achieve monopoly power, his attempts to do [sic] are of no real consequence since the adverse effects coming from monopoly, the evil which Congress intended to regulate, could not arise. In the broadest sense, all advertisements that the purveyors of goods or services offer superior goods or services could be classified as "attempts to monopolize." But most serve only to maintain the supplier's competitive position and, alas, create no monopoly, whether yearned for or not. ${ }^{165}$

Similarly, the court in Harold Friedman, Inc. v. Kroger Co. ${ }^{160}$ refused to impose Sherman Act sanctions against a grocery store 
for its act of unilaterally refusing to vacate an idle retail location, for which it had a lease, so that a competitor could rent the store and open it for business. The court held that such activity did not amount to attempted monopolization because there was no evidence that the defendant intended to harm the plaintiff on any broader scale, and because the uncontradicted market data established that defendant, with a market share of between 9.2 and 15.5 percent, lacked sufficient power actually to achieve a monopoly where the plaintiff controlled more than twenty-eight percent of the market and two other competitors each had larger shares than defendant.

In Merit Motors, Inc. v. Chrysler Corp.,$^{167}$ the court, embracing the dangerous probability requirement, likewise concluded that a defendant cannot be held liable for attempted monopolization of a market which is already dominated by others. Chrysler had been charged by one of its dealers with attempting to monopolize the market for fleet sales of Chrysler automobiles. Allegedly Chrysler had granted subsidies directly to fleet purchasers, leased cars directly to fleets and given special benefits to large fleet customers. The court determined, however, that the putative market was drawn too narrowly, and refused to entertain plaintiff's claim. It held that the actual relevant market consisted of fleet sales of all automobiles, and that the absence of a dangerous probability of success was dispositive: "In this case there is no danger of Chrysler monopolizing the entire automobile fleet market, which is the relevant market, for the market is dominated by General Motors and Ford. It follows that Chrysler cannot be found liable for attempting to monopolize it." 168 Plaintiff had argued that relevant market should not be an issue in an attempted monopolization case, but the court rejected this approach: "It would defy all logic to find on the one hand that there is a dangerous probability of monopolization by Chrysler, and, on the other hand, to find that the market which is threatened is not the relevant market and hence not susceptible to unlawful monopolization." 169

In Nifty Foods Corp. v. Great Atlantic \& Pacific Tea Co., ${ }^{170}$ the Second Circuit applied the dangerous probability test to a supplier-substitution case in which the new supplier was accused of seeking not just a new customer, but a monopoly over a nar-

167417 F. Supp. 263 (D.D.C. 1976), aff'd, 569 F.2d 666 (D.C. Cir. 1977). 168 Id. 270.

$169 \mathrm{Id}$.

170614 F.2d 832 (2d Cir. 1980). 
rowly defined "market." Plaintiff had been a supplier of privatelabel frozen waffles to defendant A\&P, a retail grocery chain. A\&P replaced plaintiff with another supplier, Pet, and plaintiff sued both A\&P and Pet on the grounds of breach of contract, unfair competition, tortious inducement of breach of contract, and violations of sections 1 and 2 of the Sherman Act. Allegedly, Pet had conspired with A\&P in effecting the substitution. The district court dismissed all of plaintiff's claims on motion and the Second Circuit affirmed. The court of appeals disposed of plaintiff's claim that Pet was attempting to monopolize an alleged market for private-label frozen waffles on the ground that the correct relevant market included all frozen waffles and that plaintiff had failed to establish a dangerous probability of success:

Pet's market share figures are the only evidence Nifty puts forward in support of its claim that Pet had such a dangerous probability of success. No reasonable jury could conclude from the rapid and continuous decline of Pet's market share, which reached a high point of $54.5 \%$ in March 1969 and fell to $33 \%$ by 1974, that there was a probability that Pet would monopolize the waffle market, let alone a dangerous probability. ${ }^{171}$

The court of appeals also found no significant probative evidence of conspiracy between A\&P and Pet in effecting the substitution. Accordingly, the section 1 claim was dismissed as well, along with the various state law claims directed toward the same conduct.

As these examples illustrate, the present standard has been reaching rational results and is not the instrument of injustice that some would suggest. The Supreme Court and the various circuits, with the exception of the Ninth, have simply demanded that one who claims an attempt to monopolize must prove that a realistic attempt to achieve a genuine monopoly over some relevant market has been made. The courts have refused to distort a cause of action with deep roots in the common and statutory law to embrace singlefirm conduct that a plaintiff might like to see punished, but for which he has invoked the wrong remedy.

\section{F. The Commission's Findings and Conclusions}

Having reviewed the state of the law, we will next examine the Commission's interpretation of these authorities, and the change that the Commission has recommended. The initial section of the 
Commission's "Proposed Competition Protection Act" contains "findings" which purportedly support the suggested amendment. Each of these findings suffers from fundamental errors, however, and warrants careful scrutiny. The first reads as follows: "Since the passage of the Sherman Act, the courts have not developed a consistent method for defining an attempt to monopolize." 172 Were this sentence to be included in a true or false examination, it would have to be marked "false." The current definition of the offense was formulated seventy-five years ago in Swift \& Co. v. United States, ${ }^{173}$ and has been followed consistently and uniformly in all but the Ninth Circuit. ${ }^{174}$ There is hardly a branch of antitrust in which there has been greater consistency. The majority of the Commissioners and the proponents of the legislation may not approve of the Holmes formulation and the scores of cases that have adhered to it without deviation, ${ }^{175}$ but that is a far cry from saying that the courts have not developed a consistent formulation. Inconsistency and lack of uniformity have been confined solely to one circuit; ${ }^{176}$ surely, national legislation is not required to eliminate an intracircuit conflict. ${ }^{177}$

The next sentence in the proposed act reads as follows: "As a result of conflicting judicial approaches, the same business conduct may be held lawful in one jurisdiction and unlawful in another." 178 Examination of the body of decisional law leads inevitably to the conclusion that this statement is incorrect. The summary of the cases reveals that there have been no conflicting judicial approaches among the circuits, again with the possible exception of the Ninth. As noted earlier though, the results reached under the Ninth Circuit rationales differ little from those under the traditional formulation. Not surprisingly, the Commission cites no example of conflicting treatment of the same conduct in different circuits.

The next sentence reads: "Anticompetitive conduct has been held outside antitrust scrutiny by some courts solely on the grounds

172 REPORT, supta note 2 , at 165.

173196 U.S. 375 (1905).

174 See note 30 supra.

$175 I d$.

176 See text accompanying notes 105-41 supra.

177 FTC Commissioner Robert Pitofsky recently said: "I wonder about the need or wisdom of the proposed legislative solution. ... [T] be ironed out eventually through appellate processes or additional litigation." Pitofsky, Antitrust Enforcement at the FTC-Focus on Legislation, 13th New England Antitrust Conference (Nov. 16, 1979).

178 REPORT, supra note 2, at 165. 
that such conduct did not imminently threaten the achievement of a monopoly position in a specific market." 179 This sentence is partially true and partially false. It may be true that a few courts have dismissed actions primarily because there was no dangerous probability that a monopoly in a properly defined market would be achieved, ${ }^{180}$ or more commonly, because no relevant market was established. ${ }^{181}$ The assumption that the conduct involved in these cases was demonstrably "anticompetitive," however, is erroneous. As noted above, the greatest number of cases in which plaintiffs invoking section 2 have been denied relief concerned unilateral refusals to deal ${ }^{182}$ or dealer terminations. ${ }^{183}$ The courts have quite properly refused to regard such conduct as anticompetitive; indeed, in many cases, it is procompetitive. It is significant that the decision in Empire Gas, the lone case cited by the Commission in support of this finding, was not based "solely on the grounds" that the conduct in question "did not imminently threaten the achievement of a monopoly position." Rather, the court rested its holding on a number of factors, including many of those since suggested by the Commission. The Commission cited no other cases in support of its finding that anticompetitive behavior has gone unpunished because of the dangerous probability requirement, and in reality only a small number of attempted monopolization cases have involved patently anticompetitive conduct. ${ }^{184}$

The next sentence of the proposed act reads: "Even where conduct that is clearly and significantly anticompetitive has been involved, courts have frequently required lengthy inquiries into present and potential market positions of defendants." 185 It is untrue that there have been a large number of cases in which courts have engaged in lengthy inquiries into the relevant market. Most attempt cases are disposed of without trial. ${ }^{186}$ It is true that courts, in dismissing complaints or granting summary judgment, have examined the undisputed facts indicating that the low market shares of the defendants raised no dangerous probability or "risk" of monopolization. By these rulings the courts have actually dispensed with market inquiries that could have been as lengthy as

$179 \mathrm{Id}$.

180 See text accompanying notes 48-50 supra.

181 See text accompanying notes $44-45$ supra.

182 See note 58 supra \& accompanying text.

183 See note 56 supra \& accompanying text.

184 See notes 56-77 supra \& accompanying text.

1S5 Reporr, supra note 2 , at 165.

186 See text accompanying notes 32-33 supra. 
they would be unnecessary. No case is cited in which clearly and significantly anticompetitive conduct was involved and in which there was a lengthy inquiry. By no stretch of the imagination can the factitious market inquiry in United States v. Empire Gas Corp. be said to have been lengthy. ${ }^{187}$

The last finding reads: "It is the conclusion of the Congress that a proviso to Section 2 of the Sherman Act is necessary to enable the statute, without deterring procompetitive behavior, to provide an effective remedy for conduct threatening to create a monopoly or otherwise to suppress competition." 188 There is no evidence in the decided cases that a new proviso is necessary to provide an effective remedy for conduct which threatens to create a monopoly or otherwise suppress competition. It is simply impossible to determine whether conduct threatens monopoly without first defining a relevant market capable of being monopolized. ${ }^{189}$ If the words mean what they say, that the creation of a monopoly is genuinely "threatened"-a conclusion predicated upon the delineation of a relevant market-then the statute is in effect saying that a new remedy is necessary to prevent that which is already forbidden. That kind of tautology would contribute nothing to the analytical framework of antitrust. ${ }^{190}$

187 See text accompanying notes 83-89 supra.

188 Report, supra note 2, at 165.

${ }^{189}$ See Walker Process Equip., Inc. v. Food Mach. \& Chem. Corp., 382 U.S. 172, 177 (1965) (emphasis added):

To establish monopolization or attempt to monopolize ... it would then be necessary to appraise the exclusionary power of the illegal patent claim in terms of the relevant market for the product involved. Without $a$ definition of that market there is no way to measure [defendant's] ability to lessen or destroy competition.

190 The Commission cites the definition of "attempts" in the Model Penal Code, requiring a "substantial step" toward commission of the offense, as authority for discarding the dangerous probability requirement. Reporr, supra note 2 , at 169 n.18 (citing Model Penal Code $\$ 5.01(1)$ (c) (Proposed Official Draft 1962)). This definition, however, differs little if at all from the Holmes formulation because it assumes that the substantial step is taken by an actor capable of completing the crime. It is also important to recognize that attempted monopolization is an offense involving structure as well as conduct, while typical criminal offenses involve elements of conduct only. As the Supreme Court pointed out in United States v. United States Gypsum Co., 438 U.S. 422 (1978):

The Sherman Act, unlike most traditional criminal statutes, does not, in clear and categorical terms, precisely identify the conduct which it proscribes. ... Simply put, the Act has not been interpreted as if it were primarily a criminal statute; it has been construed to have a "generality and adaptability comparable to that found desirable in constitutional provisions." Appalachian Coal Co. v. United States, 288 U.S. 344, 359-60 (1933).

Id. 438-39 (footnote and citations omitted). 
What, then, is it that the proposed statute purports to forbid? The proviso which would be added to section 2, quoted at the outset of this discussion, ${ }^{191}$ confirms by its very enumeration of pertinent considerations that substitution of the words "dangerous risk of monopoly" for dangerous probability of success is most likely a semantic distinction without a difference. The existing element of intent is retained, and despite the Commission's animadversions toward the present requirement that a relevant market be proved, the proviso is explicitly directed at effects on competition in such a "relevant market." Indeed, as if to underscore the quandary in which the drafters found themselves, not only must competition be threatened in a relevant market under this formulation, but the bill also specifies that an evaluation of defendant's "present or probable market power" must be factored into the analysis. Thus, the text of the report appears to be at war with the proposed legislation ${ }^{192}$-the one castigating courts for relying on market power standards, the other unavoidably requiring those same courts to assess market power in a properly defined relevant market. To have any meaningful content this market power standard would ordinarily have to require a relatively substantial market share, and thus it is difficult to fathom what change is being made in existing law. ${ }^{193}$

The only potential for divergence is in the reference to evaluation of the "anticompetitive potential of the conduct undertaken." Although this element is stated conjunctively rather than alternatively, in that the other elements in the redefined offense must also be assessed, there is nonetheless a chilling aspect to accordionlike terms of this kind, which can have as little or as much meaning as the courts desire to give them, particularly where the proviso is being added to a felony criminal statute. ${ }^{194}$ One would have to go far in researching the legislative process to find a similar example,

191 See text accompanying note 10 supra.

192 Cf. Schwimmer v. Sony Corp. of Am., 471 F. Supp. 793, 796 (E.D.N.Y. 1979) (referring to the "schizoid origins" of the Robinson-Patman Act leading to "uncertain and inconsistent interpretations").

193 The use of the word "any" in the proviso's reference to significant threats to competition in "any relevant market" should, in itself, be no more ambiguous than the language in the present section 2 which prohibits attempts to monopolize "any part of" interstate or foreign commerce. This language generally has been read to require some economically significant relevant market, with the exceptions in the Ninth Circuit already discussed. See text accompanying notes 105-48 supra.

104 See Antitrust Procedures and Penalties Act, Pub. L. No. 93-528, 88 Stat. 1706 (1974) (codified at 15 U.S.C. $\$ \$ 1-3$ (1976)) (amending 15 U.S.C. $\$ \S 1-3$ (1970)) (increasing maximum fine for each Sherman Act violation to $\$ 1$ million for corporations and $\$ 100,000$ for others, and making violation a felony punishable by up to three years in jail). 
in which a bill consists of demonstrably erroneous findings of fact and the drafters' explanation of the purpose of the legislative change is at odds with the substantive provisions of the new measure. ${ }^{195}$

What is equally disturbing is the fact that, while this recommendation evidences the Commissioners' obvious dissatisfaction with the current substantive standard for attempted monopolization, it would do nothing to expedite antitrust litigation, which is what the Commission was intended to accomplish. ${ }^{196}$ Defendant's intent and power within the relevant market would still have to be proved, and danger to competition would still have to be established, the only possible difference being in the measurement of that danger. The suggestion that so slight a shift in the law would make any difference in discovery or in the evidence presented at trial is unrealistic. No plaintiff could be expected to shortcut his discovery or pare down his trial evidence because he is trying to prove a "dangerous risk" instead of a "dangerous probability." The ambiguity inherent in the proposed multi-factor balancing test could only create uncertainty and protract litigation. The Commission's proposal would not hasten the progress of attempted monopolization cases in the slightest, and instead would serve only to encourage a greater number of such suits where evidence of market power is all but nonexistent. ${ }^{197}$ This has been the experience in the Ninth Circuit, where the court of appeals has written over thirty opinions on this one topic since Lessig, or more than one third of all the appeals reported on attempted monopolization during that time in all the circuit courts.

\section{G. Alternative Approaches to Single-Firm Conduct}

As illustrated by cases such as Coca-Cola Co. v. Howard Johnson, ${ }^{198}$ and General Communications Engineering, Inc. v. Motorola. Communications and Electronics, Inc., ${ }^{199}$ there can be a fine line

195 As Commissioner Hatch points out: "Enactment of the proposed statutory amendment would create an entirely new, untested substantive antitrust violation, enforceable by private parties, which will leave the law confused for many years to come." REPORT, supra note 2 , at 352 (separate views of Commissioner Hatch). Similarly, Commissioner McClory remarked that "this is an entirely new category of antitrust misconduct which has no relationship to attempt and market share issues and should not be legislatively tied thereto." Id. 403 (separate views of Commissioner McClory).

196 See Repont, supra note 2 , at 1.

197 See text accompanying notes $201-02$ infra. supra.

198386 F. Supp. 330 (N.D. Ga. 1974). See text accompanying notes 164-65

189421 F. Supp. 274 (N.D. Cal. 1976). See text accompanying notes 132-34 supra. In American Football League v. National Football League, 205 F. Supp. 
between aggressive but legitimate competition and attempts to monopolize, a line difficult for courts to draw and even more difficult for those in business to anticipate. Accordingly, there is ample reason for excluding single-firm behavior from the serious penalties of the antitrust laws when no dangerous probability of monopolization exists. When one firm monopolizes an economically significant market or realistically threatens such a monopoly, competition is immediately and seriously jeopardized. It was largely to combat this peril that section 2 of the Sherman Act was passed, fortified with the formidable deterrent of treble damages and criminal penalties. ${ }^{200}$ Short of this situation, however, single-firm behavior does not present so significant a threat to competition as to warrant such harsh consequences. If the dangerous probability requirement were sufficiently diluted, even the smallest of companies would find it dangerous to compete vigorously because, if its conduct were ex post facto interpreted to be anticompetitive, it would be subject to treble damage liability. ${ }^{201}$ Unfortunately, it is all too common for the miffed

60, 64-65 (D. Md. 1962), affd 323 F.2d 124 (4th Cir. 1963), the court observed that "[n]either rough competition nor unethical business conduct is sufficient" to establish an attempt to monopolize, and even a company with monopoly power "cannot be required to forego normal competitive business methods to further legitimate business ends."

In E.I. DuPont de Nemours \& Co., [1980] 3 Trade Reg. REP. (CCH) \21,770, at 21,973 (FTC), where attempted monopolization was charged, a unanimous Federal Trade Commission examined DuPont's alleged exclusionary expansion of capacity and pricing practices under the rule of reason and found them to be lawful: "[W]e are concerned with single-firm conduct, the lawfulness of which ... depend[s] on a variety of factors including the market position of the respondent, the structure of the industry, the nature of the conduct (and alternatives to such conduct), and the effect of the conduct on competition." The FTC held that DuPont's superior efficiency justified its expansion and pricing:

[T] he essence of the competitive process is to induce firms to become more efficient and to pass the benefits of the efficiency along to consumers.

That process would be ill-served by using antitrust to block hard, aggressive competition that is solidly based on efficiencies and growth opportunities, even if monopoly is a possible result.

Id., at 21,985 .

200 The legislative history of section 2 provides remarkably little insight into the content of an attempt to monopolize. The section had no counterpart in Senator Sherman's original draft and emerged instead from the Judiciary Committee, to which the bill had been referred, on April 2, 1890. There was very little debate on section 2 at all, and no illumination of the intent behind the "attempt" provision. See genetally $1 \mathrm{E}$. Kintiner, The Legislative History of thre Federal Antrinust Laws and Reiated Statutes 23-25, 292-94 (1978).

201 See Repont, supra note 2, at 350 (separate views of Commissioner Hatch), 392 (separate views of Commissioner Javits); Austin, The National Commission for the Review of Antitrust Laws and Procedures: Reports on Symptoms but Ignores Causes, 54 Notre DAME LAw. 873, 882 (1979); Hawk, supra note 37, at 1155; Note, Attempt to Monopolize Under the Sherman Act: Defendant's Market Power as a Requisite to a Prima Facie Case, 73 Colum. L. Rev. 1451, 1459-60 (1973). 
competitors of an aggressive and successful firm to bring treble damage suits against the upstart rather than to redouble their own competitive efforts. ${ }^{202}$

There would be nothing new about endeavors to fashion antitrust causes of action in order to recover treble damages for what really amount to nothing more than single-firm acts of unfair competition. Already some courts have stretched the intracorporateconspiracy doctrine beyond the limits of logic to reach, via section 1 of the Sherman Act, what is in reality single-firm behavior. ${ }^{203}$ Likewise, the now-discredited Pick-Barth doctrine frequently prompted efforts to draw single-firm conduct under the umbrella of section $I$ by characterizing it as unlawful conspiracy. ${ }^{204}$ Fictions such as

202 See REPORT, supra note 2, at 353-55 (separate views of Commíssioner Hatch, citing witnesses).

203 Expansion of the intracorporate conspiracy doctrine was precipitated by Perma Life Mufflers, Inc. v. International Parts Corp., 392 U.S. 134 (1968), and has been continued in some courts. For example, in Cromar Co. v. Nuclear Materials \& Equip. Corp., 543 F.2d 501 (3d Cir. 1976), the Third Circuit seemingly abandoned the rule that a parent cannot be liable for conspiracy with its wholly-owned subsidiary unless the two corporations hold themselves out as competitors. In more recent cases, however, courts have been unwilling to find conspiracy where the parent and subsidiaries are under common control and operate as an integrated enterprise. See, e.g., Las Vegas Sun, Inc. v. Summa Corp., 610 F.2d 614 (9th Cir. 1979); Giant Paper \& Film Corp. v. Albemarle Paper Co., 430 F. Supp. 981, 985-86 (S.D.N.Y. 1977); Aaron E. Levine \& Co. v. Calkraft Paper Co., 429 F. Supp. 1039 (E.D. Mich. 1976). But cf. Far Eastern Coconut Co. v. Sun Ripe Coconut Corp., 1979-2 Trade Cas. I62,878 (E.D.N.Y. 1979) (two corporations with common ownership and operation not incapable of conspiracy). See generally Handler, Twenty-Five Years of Antitrust, 73 Colom. L. REv. 415, 452-53 (1973). The key to liability under the majority rule remains whether the related companies hold themselves out as competitors. See KieferStewart Co. v. Joseph E. Seagram \& Sons, 340 U.S. 211, 215 (1951); Las Vegas Sun, Inc. v. Summa Corp., 610 F.2d 614, 618 (9th Cir. 1979); Beckman v. Walter Kidde \& Co., 316 F. Supp. 1321, 1325 (E.D.N.Y. 1970), aff'd per curiam, 451 F.2d 593 (2d Cir. 1971), cert. denied, 408 U.S. 922 (1972).

204 In Albert Pick-Barth Co. v. Mitchell Woodbury Corp., 57 F.2d 96, 102 (Ist Cir.), cert. denied, 286 U.S. 552 (1932), the First Circuit held that conspiracy to eliminate a competitor in interstate commerce by unfair means is a per se violation of section 1 of the Sherman Act regardless whether an unreasonable restraint of trade results. When it became apparent that the conspiracies claimed in cases of this type were largely fictitious, and that the cases involved single-firm unfair competition cognizable at the common law, the courts beat a hasty retreat. This retreat has taken two forms. One is to measure liability under the rule of reason. Northwest Power Prods., Inc. v. Omark Indus., Inc., 576 F.2d 83 (5th Cir. 1978), cert. denied, 439 U.S. 1116 (1979); George R. Whitten, Jr., Inc. v. Paddock Pool Bldrs., Inc., 508 F.2d 547 (1st Cir. 1974), cert. denied, 421 U.S. 1004 (1975); Petroleum for Contractors, Inc. v. Mobil Oil Corp., 1978-2 Trade Cas. If 62,151 (S.D.N.Y. 1978); All Label Record Serv., Inc. v. Mr. Wiggs Dep't Stores, Inc., 1978-1 Trade Cas. If 62,073 (N.D. Ohio 1978); Mar Food Corp. v. Doane, 405 F. Supp. 730 (N.D. Ill. 1975); duPont Walston, Inc. v. E.F. Hutton \& Co., 368 F. Supp. 306 (S.D. Fla. 1973). The other is to hold that the conduct, though perhaps actionable under other laws, is without antitrust liability. Stifel, Nicholaus \& Co. v. Dain, Kalman \& Quail, Inc., 578 F.2d 1256 (8th Cir. 1978); Redwing Carriers, Inc. v. McKenzie Tank Lines, Inc., 443 F. Supp. 639 (N.D. Fla. 1977), aff'd per curiam, 594 F.2d 114 (5th Cir. 1979); General Comm's Eng'r, Inc. v. 
these are not the appropriate avenues for reaching single-firm behavior.

On the other hand, the Federal Trade Commission is squarely empowered to enjoin "unfair methods of competition" and "unfair and deceptive acts and practices," flexible concepts that can be adapted to changing circumstances. Its experience in this area spans sixty-five years and the orders and opinions issued are legion. Most of the FTC's cases have related to false advertising, ${ }^{205}$ passing off, ${ }^{208}$ misbranding, ${ }^{207}$ deceptive packaging, ${ }^{208}$ commercial disparagement ${ }^{209}$ and other unfair competitive behavior, ${ }^{210}$ conduct properly described as unfair methods of competition or unfair and deceptive acts and practices. To a limited extent the FTC has also proceeded against single-actor misconduct that may warrant the hyperbolic description of "predatory and vicious." 211 Exam-

Motorola Comm's \& Elecs., Inc., 421 F. Supp. 274 (N.D. Cal. 1976); Vogue Instrument Corp. v. Lem Instruments Corp., 40 F.R.D. 497 (S.D.N.Y. 1966). Whatever the approach, the ultimate result in this body of cases, which never should have been brought in the first instance, has been dismissal of the claims. See generally Note, The Pick-Barth Doctrine: Should Unfair Competition Belong Under the Sherman Act?, 31 BArLOR L. Rev. 253 (1979).

205 E.g., Raymond Lee Organization, Inc., 92 F.T.C. 489 (1978) (services provided to inventors falsely described); Porter \& Dietsch, Inc., 90 F.T.C. 770 (1977) (weight reduction tablets); Warner-Lambert Co., 86 F.T.C. 1398 (1975) (Listerine), modified, 562 F.2d 749 (D.C. Cir. 1977); Hollywood Carpets, Inc., 86 F.T.C. 784 (1975) (false price claims and misrepresentation of retail facility as a warehouse); Fedders Corp., 85 F.T.C. 38 (1975) (air conditioners); Standard Oil Co., 84 F.T.C. 1401 (1974) (gasoline additive), modified, 577 F.2d 653 (9th Cir. 1978); ITT Cont. Baking Co., 83 F.T.C. 865 (1973) ("Wonder Bread"), modified, 90 F.T.C. 181 (1977); Resort Car Rental Sys., Inc., 83 F.T.C. 231 (1973) ("Dollar a Day" trade name misleading), aff', 518 F.2d 962 (9th Cir. 1975), cert. denied, 423 U.S. 827 (1975); National Bakers Servs., Inc., 62 F.T.C. 1115 (1963) (thinly sliced bread misrepresented as low calorie); Bakers Franchise Corp., 59 F.T.C. 70 (1961) (same), affd, 302 F.2d 258 (3d Cir. 1962). See also Handler, The Jurisdiction of the Federal Trade Commission over False Advertising, 31 CoLum. L. REv. 527 (1931).

206 E.g., Universe Chems., Inc., 79 F.T.C. 493 (1971) (chemicals falsely represented as those of a particular manufacturer); L'Argene Prods. Co., 73 F.T.C. 16 (1968) (same; perfumes).

207 E.g., Verrazzano Trading Corp., 91 F.T.C. 888 (1978) (misrepresentation of fiber content of textile products); H. Myerson Sons, 78 F.T.C. 464 (1971) (same); Panat Jewelry Co., 71 F.T.C. 99 (1967) (domestic perfume misrepresented to be imported); Detra Watch Case Corp., 66 F.T.C. 848 (1964) (misrepresentation of metallic composition and origin of watch cases); Hugh J. McLaughlin \& Son, 66 F.T.C. 387 (1964) (reconstructed golf balls sold as new).

${ }^{20 S}$ E.g., Walco Toy Co., 83 F.T.C. 1783 (1974) (oversized boxes); Papercraft Corp., [1963-1965 Transfer Binder] Trade REg. ReP. (CCH) \ 16,721 (F.T.C. 1964) (same).

209 E.g., Carter Prods., Inc., 60 F.T.C. 782 (1962) (representing competitor's products with other substances in advertisements), vacated, 323 F.2d 523 (5th Cir. 1963).

210 E.g., S \& S Pharmaceutical Co., 72 F.T.C. 765 (1967) (forcing products upon retailers).

211 E.g., Washington Crab Ass'n, 66 F.T.C. 45 (1964) (threats of physical violence). 
ples of predation can also be found in cases brought by the Department of Justice under the Sherman Act and either litigated or resolved through consent decrees. ${ }^{212}$

It is rather remarkable that as responsible a body as the National Commission should proclaim the prevalance of predation in modern business behavior and yet not marshal any supporting evidence, nor enumerate the acts and practices that it believes should be visited with section 2 liability. It is equally remarkable that an agency which has the broad powers of the FTC, and whose most urgent responsibility would be the extirpation of predatory acts and practices, should have given so little attention to such improprieties in recent years. The examples of FTC proceedings against such serious and unambiguous conduct stem largely from the earlier years of the Commission's existence. ${ }^{213}$ Despite its recent inaction,

212 See, e.g., United States v. American Tobacco Co., 221 U.S. 106 (1911) (employing "fighting brands"); Standard Oil Co. v. United States, 221 U.S. 1, 42, 43 (1911) (local price cutting, espionage, establishment of bogus independents, granting rebates to preferred customers, exacting rebates and preferences from railroads); Patterson v. United States, 222 F. 599 (6th Cir.) (espionage, enticement of competitors' employees, manufacturing inferior imitations of competitors' products, threatening infringement suits in bad faith, maintaining bogus independents, inducing breach of contract, shadowing competitors' salesmen, circulating false reports of competitors' financial standing, selling competitors' products below cost, and labeling an exhibit of competitors' machines as junk), cert. denied, 238 U.S. 635 (1915); United States v. American Can Co., 230 F. 859, 874-75 (D. Md. 1916) (cutting off competitors' sources of supply), appeal dismissed, 256 U.S. 706 (1921); United States v. National Cash Register Co., reported in DECREes AND JudGarents In Federal AntI-Trust Cases (1918 [hereinafter cited as Decrees], at 315 (S.D. Ohio 1916) (espionage, enticement of competitors' employees, manufacturing inferior imitation products, inducing breach of contract, threatening competitors and customers); United States v. S.F. Bowser \& Co., Decrees, supra, at 587 (D. Ind. 1915) (inducing breach of contract, disparaging business methods of competitors, local price cutting, commercial bribery, espionage, harassing litigation); United States v. International Harvester Co., 214 F. 987 (D. Minn. 1914) (foreclosing competitors from distribution channels through exclusive dealing contracts), appeal dismissed, 248 U.S. 587 (1918), supplemental bill, 274 U.S. 693 (1927); United States v. American Thread Co., Decrees, supra, at 449 (D.N.J. 1914) ("fighting brands," "flying squadrons," local price-cutting); United States v. Burroughs Adding Mach. Co., Decrees, supra, at 457 (E.D. Mich. 1913) (inducing breach of contract, espionage); United States v. Central-West Publish. Co., DECREES, supra, at 359 (N.D. III. 1912) (threatening to compete with competitors' customers, inducing breach of contract, disparaging business methods of competitors, local price-cutting, maintaining bogus independents, compelling sale of competitors' plants by threatening intensive competition); United States v. Aluminum Co. of Am., Decrees, supra, at 341 (W.D. Pa. 1912) (disclosure of intended use of raw materials as a condition precedent to its sale, exclusive dealing arrangements); United States v. E.I. duPont de Nemours \& Co., Decrees, supra, at 195 (D. Del. 1911) (maintaining bogus independents); United States v. General Elec. Co., DECREES, supra, at 267 (N.D. Ohio 1911) (maintaining bogus independents). See generally Handler, Industrial Mergers and the Anti-Trust Laws, 32 ColuM. L. Rev. 179 (1932); Handler, Unfair Competition, 21 Iowa L. REv. 175, 214-20 (1936).

213 See cases collected in Handler, The Jurisdiction of the Federal Trade Commission over False Advertising, 31 CoLUM. L. REv. 527, 555-58 (1931). 
the FTC, a body with appropriations running as high as $\$ 80$ million a year, ${ }^{214}$ has the indisputable power to prevent that which the $\mathrm{Na}$ tional Commission would curb through the private treble damage remedy. The FTG is not a toothless agency that must rely on precatory pronouncements to carry out its charter. ${ }^{215}$

The FTC's first order of business should be to use its ample powers of investigation to determine whether predation in modern business practice constitutes a real evil. If it does, the FTC should exercise its powers to eradicate such practices. Given the inclination, the FTC has sufficient authority and is adequately equipped to make a frontal attack on single-firm misconduct. Is it not possible that its current inaction is attributable to the fact that predation exists more in the minds of the proponents of change than in the real business world?

Another appropriate and presently available remedy for singlefirm misconduct is common law unfair competition, which has an even wider ambit than the FTC's mandate and is available to private plaintiffs. Covered under this heading is such behavior as misappropriation of trade secrets, false advertising and misbranding, passing off, disparagement of competitors' goods, molestation

214 See Federal Trade Commission Improvements Act of 1980, Pub. L. No. 96-252, $\$ 17(2), 94$ Stat. 391 (1980) (amending 15 U.S.C. $57 \mathrm{c}$ (1976)).

215 The Commission has been significantly strengthened by recent legislation. The Trans-Alaska Pipeline Authorization Act, Pub. L. No. 93-153, 87 Stat. 576, 584 (1973) (amending 15 U.S.C. $\$ \$ 45,46,53,56$ ) authorized the Commission to seek injunctive relief in court (15 U.S.C. $\$ 45(1), 53($ a) (1976)) and to represent itself in court should the Justice Department not act on its behalf (15 U.S.C. $\$ 53$ (1976)); increased the maximum civil penalty for violating a cease and desist order from $\$ 5,000$ to $\$ 10,000$ (15 U.S.C. $\$ 45(1)$ (1976)); enabled the Commission to obtain information from banks and common carriers exempt from the Commission's regulation where necessary for its investigations (15 U.S.C. $46(h)$ (1976)); and shifted authority over agency requests for data, including the Commission's "line of business" reporting program, from the Office of Management and Budget to the Comptroller General (44 U.S.C. \$3512 (1976)).

The Magnuson-Moss Warranty-Federal Trade Commission Improvement Act, Pub. L. No. 93-637, 88 Stat. 2183, 2193 (1975) (codified in 15 U.S.C.) expanded the Commission's jurisdiction to activities "in or affecting" interstate commerce (15 U.S.C. $\$ 45$ (1976)); authorized the Commission to promulgate rules defining unfair or deceptive acts and practices (15 U.S.C. $\$ 57 a$ (1976)); enabled the Commission to obtain evidence from persons and partnerships as well as from corporations, which already had been covered (15 U.S.C. $\$ 46(\mathrm{a})$ (1976)); authorized the Commission to bring civil penalty actions for knowing violation of a trade regulation rule or for knowingly engaging in conduct of a type previously found unfair and deceptive in a cease and desist proceeding (15 U.S.C. $\$ 45(\mathrm{~m})$ (1976)); and authorized the Commission to seek judicial redress for persons injured by unfair or deceptive acts or practices (15 U.S.C. $\$ 57 \mathrm{~b}(\mathrm{a})(1976)$ )).

The Hart-Scott-Rodino Antitrust Improvements Act of 1976, Pub. L. No. 94435,90 Stat. 1383 (codified in 15 U.S.C.) provided for premerger notification to the Commission as well as to the Justice Department (15 U.S.C. $\$ 18(a)$ (1976)) and authorized either agency to seek a preliminary injunction to prevent consummation of suspect acquisitions (15 U.S.C. $\$ 18 \mathrm{a}(\mathrm{f})(1976)$ ). 
and physical interference, and interference with contractual relationships. ${ }^{216}$ This remedy is already available to prevent predation; ${ }^{217}$ all that is necessary is that it be invoked. The only significant difference between the common law of unfair competition and the Commission's proposed new remedy is that unfair competition carries with it single damages and, except in diversity cases, state court jurisdiction. Federal jurisdiction could be created if necessary, ${ }^{218}$ however, following the precedent of section $43(\mathrm{a})$ of the Lanham Trade-Mark Act. ${ }^{219}$ It would seem prudent, on the

216 See generally M. Handler, Cases and Materials on Bustness Torts (1972); E. Kinter, A Pramer on the Law of Deceptive Practices (1971); Handler, Unfair Competition, 21 Iowa L. REv. 175 (1936).

${ }^{217}$ See generally M. Handler, Cases and Materials on Busuness Torts (1972).

218 See Hawk, supra note 37, at 1153-55; Peterson, The Legislative Mandate of Sears and Compco: A Plea for a Federal Law of Unfair Competition, 69 Dick. L. REv. 347 ( 1965 ).

219 The Lanham Trade-Mark Act, enacted in 1946, includes what has become, in the opinion of many, a new statutory federal law of unfair competition. See, e.g., Germain, Unfair Trade Practices Under Section 43(a) of the Lanham Act, 49 IND. L.J. 84 ( 1973); Note, The Lanham Trademark Act, Section 43(a)-A Hidden National Law of Unfair Competition, 14 WASEBURN L.J. 330 (1975) [hereinafter cited as WAsforurn Note]. Section 43(a), 15 U.S.C. §1125(a) (1976), prohibits the use of false representations, descriptions or designations of origin in connection with any goods or services, and grants a right of action to "any person who believes that he is or is likely to be damaged" thereby.

For over twenty years this provision was little more than a "sleeping giant." See Maternally Yours, Inc. v. Your Maternity Shop, Inc., 234 F.2d 538, 546 (2d Cir. 1956) (Clark, J., concurring); WAshourn Note, supra at 331. Today it has blossomed into a significant body of federal law applicable to some of the most common forms of unfair competition-false advertising, passing off, simulation of competitors' brand names and use of deceptively similar trade dress. It probably does not reach such other practices as disparagement of competitors' products not incidental to false representation, however, or molestation or interference with contractual relations. See Fur Information \& Fashion Council, Inc. v. E. F. Timme \& Son, 501 F.2d 1048, 1052 (2d Cir.), cert. denied, 419 U.S. 1022 (1974); Germain, supra, at 103 n.125; cf. American Consumers, Inc. v. Kroger Co., 416 F. Supp. 1210, 1212-13 (E.D. Tenn. 1976) (court precluded by 1963 Sixth Circuit precedent from holding that defendant's false statements with regard to the price of its goods in comparison with that of plaintiff's goods was violative of $\S 43(a))$. Yet it demonstrates that a federal law of unfair competition can exist and flourish, and that if the other remedies available today are inadequate, a federal law of unfair competition more inclusive than section $43(\mathrm{a})$ could be enacted to deal directly and effectively with predatory acts and practices.

Such a concept is not revolutionary-there once was a federal common law of unfair competition in this country. Prior to 1938, when Erie R.R. v. Tompkins, 304 U.S. 64 (1938), extinguished this jurisprudence, the federal judiciary had developed a substantial body of law on single-firm misconduct in diversity cases. See Burn, The National Law of Unfair Competition, 62 Harv. L. Rev. 987, 990 (1949); Handler, Unfair Competition, 21 Iowa L. Rev. 175 (1936). After 1938 plaintiffs attempted to resurrect this law by claiming a private right of action under the FTC Act, but these bids have proved unsuccessful, the courts holding that this was not the congressional intent. See National Fruit Prod. Co. v. DwinellWright Co., 47 F. Supp. 499 (D. Mass. 1942) (Wyzanski, J.) (need for national law of unfair competition termed "peculiarly appropriate for consideration by the legislative .. . branch"), aff'd, 140 F.2d 618 (Ist Cir. 1944); accord, e.g., Hollo- 
other hand, to retain single damages where monopoly is not seriously threatened.

Other remedies are not in short supply. They include state "Little FTC Acts" ${ }^{220}$ and state franchising acts, ${ }^{221}$ as well as the federal Automobile Dealers' Day in Court Act ${ }^{222}$ and the Petroleum Marketing Practices Act, ${ }^{223}$ all of which reach at least some of the conduct commonly charged in attempted monopolization cases. As these remedies become increasingly accepted and familiar, the struggle to expand the scope of the attempted monopolization offense may lose much of its vigor, especially in dealer termination cases. ${ }^{224}$

The Commission seems oblivious to the fact that the unsuccessful litigants in most attempted monopolization suits simply may have resorted to the wrong instrument to reach the questioned behavior and, thus, that the Commission itself may be reaching for the wrong tool. Most plaintiffs who fail to make out a case of

way v. Bristol-Myers Corp., 485 F.2d 986 (D.C. Cir. 1973); Carlson v. Coca Cola Co., 483 F.2d 279 (9th Cir. 1973) (citing additional cases); Greenberg v. Michigan Optometric Ass'n, 483 F. Supp. 142 (E.D. Mich. 1980). But see Guernsey v. Rich Plan, 408 F. Supp. 582 (N.D. Ind. 1976).

Congress had no reason to create a private federal remedy for unfair competition in 1914 because one already existed, at least in diversity actions. Moreover, Congress intentionally drafted the FTC Act to reach beyond unfair competition to "unfair methods of competition," a broader phrase the interpretation and employment of which were to be entrusted to an expert body. See Handler, Unfair Competition, 21 Iowa L. Rev. 175, 237-39 (1936). Courts have consistently balked at placing this unguided missile in the hands of private plaintiffs. See, e.g., Holloway v. Bristol-Myers Corp., 485 F.2d 986, 991 (D.C. Cir. 1973) (Leventhal, J.; FTC Act "was intended to be the exclusive domain of the specialized agency expressly charged with its enforcement").

220 Ten states-Hawaii, Idaho, Massachusetts, New Hampshire, New Mexico, North Carolina, South Carolina, Vermont, Washington, and Wisconsin-and the Commonwealth of Puerto Rico prohibit all unfair methods of competition. HawaIr Rev. Stat. $\$ 480-2$ (1976); IDaho Code $\$ 48-104$ (1947); Mass. AM. Laws ch. 93A, \$2 (Law. Co-op.); N.H. Rev. Stat. ANN. \$ 358-A:2 (Supp. 1979); N.M. Stat. Ann. \$57-12-3 (1978); N.C. Gen. Stat. \$75-1.1 (Supp. 1979); S.C. Code \$ 39-5-20 (1976); Vt. STat. ANN. tit. 9, \$2453 (1970 \& Supp. 1980); Wash. Rev. CoDe $\$ 19,86.020$ (1978); WIS. Stat. ANN. \$100.20 (1973 \& Supp. (1980); P.R. LAwS ANN. tit. 10, $\$ 259$ (1976 \& Supp. 1979). The remainder prohibit certain specified acts, the most common being sales below cost, price discrimination, and deceptive advertising. See generally AMERTCaN Bar Assoctation, Section of Antitrust Law, State Antitrust Laws (1974).

221 See Commerce Cleaning House, State Business Franchase Disclosure and Relattonshit Laws (1978); 15 G. Gitckman, Bustness Organtzations Franchising $\$ 3.03$ (1980).

22215 U.S.C. $\$ 1221$ (1976).

22315 U.S.C. $\$ 2801$ (Supp. III 1979). Cf. Arnott v. American Oil Co., 609 F.2d 873 (8th Cir. 1979) (breach of fiduciary duty), cert. denied, $100 \mathrm{~S}$. Ct. 1852 (1980); Picture Lake Campground, Inc. v. Holiday Inns, Inc., 978 ANTrTRUst \& Trade Reg. Rep. (BNA) E-4 (E.D. Va. 1980) (rejecting Arnott).

224 See Brown, ABA Forum Committee on Franchising, N.Y.L.J., Dec. 11, 1979 , at 1 , col. 1,2 , col. 4 . 
attempted monopolization lack even the most basic evidence to support a claim, and such plaintiffs would be equally unsuccessful under the Commission's proposed rule. Unfair or restrictive singlefirm conduct should be handled by the Government as an unfair act or practice or unfair method of competition. For private plaintiffs, it should be remedied under the law of unfair competitionproviding federal jurisdiction if necessary-or under an applicable state or federal statute. ${ }^{225}$ We should recognize single-firm conduct for what it is and deal with it directly, rather than distort important remedies and principles designed for other purposes.226 As the courts have observed in rejecting section 2 claims involving singlefirm activity, the antitrust laws "do not purport to formulate a code of business morality" ${ }^{227}$ nor are they "a panacea for all evils that may infect business life." 228

\section{No-Conduct Monopolization}

The second of the Commission's substantive recommendations concerns "no-conduct" or "no-fault" monopolization. In the belief that proof of "deliberate conduct undertaken with the general intent of acquiring or maintaining [monopoly] power . . . serves to protract Section 2 litigation unduly and to reduce the effectiveness of structural relief," 229 the Commission recommended that the Government be permitted to obtain such relief in monopolization cases without being required to prove deliberate acquisition or maintenance of monopoly power. ${ }^{230}$ The no-conduct standard would require a court, upon a showing of what is termed "persistent monopoly power," to formulate a plan to dissipate that power. ${ }^{231}$ "Persistent monopoly power" is nowhere formally defined, ${ }^{232}$ yet the recommendation rests upon the theoretical assump-

225 See notes 216-19 supra \& accompanying text.

228 See REPORT, supra note 2, at 350 (separate views of Commissioner Hatch). 227 B \& B Oil \& Chem. Co. v. Franklin Oil Corp., 293 F. Supp. 1313, 1317 (E.D. Mich. 1968); accord, N.W. Controls, Inc. v. Outboard Marine Corp., 333 F. Supp. 493 (D. Del. 1971). As the Supreme Court stated in Hunt v. Crumboch, 325 U.S. 821, 826 (1945): "[The Sherman] Act does not purport to afford remedies for all torts committed by or against persons engaged in interstate commerce."

228 Berkey Photo, Inc. v. Eastman Kodak Co., 603 F.2d 263, 288 n.41 (2d Cir. 1979).

229 REPoRr, supra note 2, at 151-52 (footnote omitted).

230 Id. 158-59.

231 Id. 152.

232 Senator Javits shed the only ray of light on this subject when he remarked that "[t]he example [of persistent monopoly power] bruited about informally was a monopoly of 5 years' duration (a monopoly defined as 65 percent of the market) 
tion that "persistent monopoly power, in all but the most exceptional instance, can only result from culpable conduct." 233

One would have thought that before suggesting major surgery on the body economic, the Commission would have developed facts sufficient to demonstrate the necessity and desirability of such a radical change. Although the Commission did recommend further congressional study of this proposal, it urged exploration of the probable impact of the measure, not the need for it. ${ }^{234}$ In fact, both the impact and the necessity of the proposal should have had the benefit of a factual predicate before being presented to the American public with the Commission's endorsement.

As to impact, the Commission candidly admits that "much of its uncertainty" in this area "arises from the fact that little information is presently available as to the likely number of industries which would be affected." ${ }^{235}$ This point, passed over as if a detail, is of extraordinary importance. Perhaps the most significant practical question arising from the Commission's recommendations is which industries and companies might be affected by the proposed legislation. The proponents of the no-conduct plan, who presumably are experts in the study of industrial organization, should have provided the public with a list of those companies that possess monopoly power in a reasonably defined relevant market and have persistently maintained such power without indulgence in unlawful conduct. Is it not of some importance to know whether we are dealing with five, ten, a hundred, or perhaps even a thousand companies? ${ }^{236}$

It would seem that the proper sequence in the legislative process should be first to identify the mischief, then to ascertain the facts, and finally to draft legislation to correct the evil uncovered. Here, lacking even the most sketchy factual support, the Commission would create power in the Government to dismember companies and industries whenever it is determined that there is monopoly power and that such power has persisted over some span of time, regardless whether the power was properly obtained and exercised without injuring anyone. The Commission has performed neither a cost-benefit analysis of the proposal, nor a case study of the enterprises that would be subject to the recommendaand annual sales of over $\$ 500$ million." Id. 392 (separate views of Commissioner Javits ).

233 Id. 156 (footnote omitted).

234 Id. 162-63.

$235 I d .162$.

236 See id. 364 (separate views of Commissioner Hatch). 
tion, to determine what effect dismemberment would have on suppliers, customers, employees, stockholders, localities where their plants are located, municipalities dependent upon the taxes which they pay, or the general economy through the possible loss of their efficiencies. Nor is adequate account taken of the disincentives implicit in any such proposal. The only justification for so extraordinary a recommendation is that, in economic theory, monopoly operates to the disadvantage of the public. We do not mete out economic drawing-and-quartering on the basis of theory, however, particularly when the theory exists in a vacuum. The proponents of this measure provide no account of instances in which the public interest has been ill-served by monopoly absent extrinsic acts of wrongdoing. Without such factual support and analysis, the Commission's Report informs the public neither of the specific evils the "no-fault" proposals are intended to correct nor of the likely results of the proposed corrections.

\section{A. The Commission's Presuppositions}

The no-conduct proposal rests, essentially, on two unproved presuppositions. The first is that "maintenance of monopoly power over a significant period of time would, in all but the rarest circumstances, be possible only by means of culpable behavior." ${ }^{237}$ We will assume at the outset that "monopoly power" is to be defined in the traditional sense of the power of a single firm to fix prices or exclude competitors; ${ }^{238}$ if "monopoly power" were to encompass the concept of "shared monopoly" the potential of noconduct liability would be staggering. ${ }^{239}$

Assuming the traditional definition, there is simply no truth to the proposition that virtually all monopoly power that exists over a significant period may be attributed to culpable conduct. Antitrust theory has consistently recognized the inevitability of certain natural monopolies. Moreover, experience teaches that the evil ascribed to monopoly in theory does not necessarily occur in the business world. This was recognized by Judge Learned

237 Id. 155.

238 See United States v. Grinnell Corp., 384 U.S. 563, 571 (1966); United States v. E.I. du Pont de Nemours \& Co., 351 U.S. 377, 391 (1956).

239 The Commission appears to have been addressing only single-firm monopolization because it relies on the argument that "a fundamental tenet of the antitrust laws [is] that markets ought not be under the control of a single individual or enterprise." REPORT, supra note 2, at 156 (emphasis added). See generally $3 \mathrm{P}$.

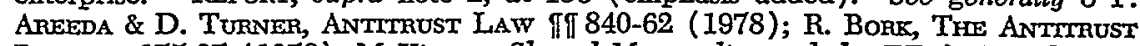
Paradox 175-97 (1978); McKinney, Shated Monopolies and the FTC's Cereal Case, 47 ANTITRUST L.J. 1127 (1979) (and sources cited therein). 
Hand and Justice Douglas, who explicitly sanctioned acquisition or maintenance of monopoly power by "growth or development as a consequence of a superior product, business acumen, or historic accident." 240 This concept is illustrated graphically by the monopoly that is enjoyed by a patent holder, given to him as a temporary reward for innovation and investment. It is also manifest in trade secret monopolies and monopolies in markets that are marginally profitable and will not support a second seller. ${ }^{241}$

The second presupposition behind the concept of no-fault monopoly is that monopoly imposes continuing social and economic costs on society through higher prices, reduced output, decreased diversity and lack of alternative suppliers. ${ }^{242}$ This, of course, is pure theory. But the facts in the real world do not always conform to theoretical models. The Commission undertook no empirical studies. It would randomly restructure the American economy on the basis of unsubstantiated speculation.

Concededly, the Commission had only six months in which to prepare its report, hardly enough time to assemble a detailed factual analysis. But this is no excuse for proceeding to endorse so profound a change in the law. Indeed, it is cause for proceeding with a considerable degree of caution. At most, the Commission should have suggested that a factual investigation be undertaken in this area to determine whether any change is warranted.

\section{B. The State of the Law on Structural Relief}

Ignoring the facts is only part of the problem, however. The Commission also is to be faulted for its puzzling disregard of decades of monopoly jurisprudence. After reading the report, one is compelled to assume that existing law sets insuperable obstacles against a successful Government monopoly suit. One would expect to find that the Government has amassed an impressive record of defeats over the years, and that structural relief has been virtually unheard of in our courts. Yet if one examines the record, the facts are to the contrary. In the early years, while antitrust was still in its experimental stage, spectacular victories were achieved in such impor-

240 United States v. Grinnell Corp., 384 U.S. 563, 570-71 (1966). In United States v. Aluminum Co. of America, 148 F.2d 416, 430 (2d Cir. 1945), Judge Hand observed, "[a] single producer may be the survivor out of a group of active competitors, merely by virtue of his superior skill, foresight and industry. . . . The successful competitor, having been urged to compete, must not be turned upon when he wins."

241 See M. Handler, Trade Regulation 12 (4th ed. 1967).

242 REPORT, supta note 2 , at 155-56. 
tant fields as petroleum, tobacco and railway transportation. ${ }^{243}$ In more modern times, the Government successfully prosecuted section 2 actions in United States v. Aluminum Co. of America ${ }^{244}$ and United States v. United Shoe Machinery Corp. ${ }^{245}$ It has also been able to obtain structural relief in recent years in such cases as United States v. Grinnell Corp., ${ }^{248}$ Citizen Publishing Co. v. United States, ${ }^{247}$ International Boxing Club of New York, Inc. v. United States, ${ }^{248}$ and others, ${ }^{249}$ while the FTC has obtained such relief in Golden Grain Macaroni Co. v. FTC ${ }^{250}$ and L.G. Balfour Co. v. FTC. ${ }^{251}$ Proving a violation of section 2 was difficult in these actions, of course, but considering the consequences of finding illegality and the dimension of the interests involved, how can it be consistent with our conception of due process to punish without proof of wrongdoing?

A serious criticism, therefore, of the Commission's monopoly recommendation is that it has furnished the public with neither a proper bill of particulars on the facts nor an adequate analysis of the relevant law. The Commission has not even begun to discharge the burden of proof devolving upon proponents of legislative change.

243 Standard Oil Co. v. United States, 221 U.S. 1 (1911); United States v. American Tobacco Co., 221 U.S. 106 (1911); Northern Secs. Co. v. United States, 193 U.S. 197 (1904). See Handler, Industrial Mergers and the Anti-Trust Laws, 32 Colum. L. Rev. 179 (1932).

244 91 F. Supp. 333 (S.D.N.Y. 1950) (enforcing 148 F.2d 416 (2d Cir. 1945))

(divestiture of Canadian subsidiary).

245391 U.S. 244 (1968) (dissolution ordered).

246384 U.S. 563 (1966) (divestiture of controlled corporations ordered).

247394 U.S. 131 (1969) (divestiture of one of two jointly operated newspapers).

248358 U.S. 242 (1959) (divestiture of promoters' stock in arena).

249 United States v. E.I. du Pont de Nemours and Co., 366 U.S. 316 (1961) (divestiture of all General Motors stock owned by du Pont and its holding company); Maryland \& Va. Milk Producers Ass'n v. United States, 362 U.S. 458 (1960) (divestiture of assets of acquired competitor); Besser Mfg. Co. v. United States, 343 U.S. 444 (1952) (compulsory sale and licensing of patents); United States v. United Shoe Mach. Corp., 110 F. Supp. 295 (D. Mass. 1953) (licensing of patents on a reasonable royalty basis), aff'd per curiam, 347 U.S. 521 (1954). See also Schine Chain Theatres, Inc. v. United States, 334 U.S. 110 (1958) (dissolution of pooling agreements); United States v. National Lead Co., 332 U.S. 319 (1947) (divestiture); Hartford-Empire Co. v. United States, 323 U.S. 386 (divestiture and compulsory licensing), clarified, 324 U.S. 570 (1945); United States v. Crescent Amusement Co., 323 U.S. 173 (1944) (divestiture); United States v. Pitney-Bowes Inc., 1959 Trade Cas. If 69,235 (D. Conn. 1959) (royaltyfree patent license ordered); United States v. International Harvester Co., 214 F. 987 (D. Minn. 1914) (dissolution), modification denied, 10 F.2d 827 (D. Minn. 1926), aff'd, 274 U.S. 693 (1927).

250472 F.2d 882 (9th Cir. 1972) (divestiture of interests in two other businesses in industry), cert. denied, 412 U.S. 918 (1973).

251442 F.2d 1 (7th Cir. 1971) (divestiture of subsidiary). 


\section{G. Monopoly Power and Persistence}

Equally serious is the Commission's failure to define what is meant by "monopoly power" under the new scheme or to give any workable content to the concept of "persistence." Monopoly power can exist only in the context of a relevant market, ${ }^{252}$ but virtually every student of antitrust who has had any experience in the trial of merger and monopoly cases agrees that the case law on the delineation of markets is a dismal swamp. The decisions are totally unprincipled.253 While there has been some salutary change resulting from the Brown Shoe guidelines on the definition of submarkets, ${ }^{284}$ the courts have erratically applied these principles in a fashion that makes prediction impossible.

We know from our experience with section 7 of the Clayton Act that markets can be gerrymandered so that a minnow is made to look like a whale. All that is necessary, in Justice Fortas's words, is to adopt a "red-haired, bearded, one-eyed man-with-a-limp classification" in defining both product and geographic markets. ${ }^{255}$ To illustrate, set forth below in parallel columns are some examples of the bizarre ways in which markets are presently being defined. One column lists markets which have been adopted in various monopoly and merger situations and the other column lists alleged markets which have been rejected. The reader is invited to divine which is which:

1. Aluminum Culvert Pipe

2. First-Run Feature Films

3. Bananas

4. Corn Syrup

5. Liquid Petroleum Gas

6. Aluminum Gurtain Wall
Cast Iron Pipe

Feature Films for Television

Chrysanthemums

Citric Acid

Coal

Prefabricated Metal Buildings 250

252 Walker Process Equip., Inc. v. Food Mach. \& Chem. Corp., 382 U.S. 172, 177 (1965) (" $t$ t]o establish monopolization ... . It would then be necessary to appraise the exclusionary power . . . in terms of the relevant market for the product involved"). See REPORT, supra note 2, at 342 (separate views of Commissioner Fox) ("[m]onopoly power presumes a well-defined market within which the defendant can raise prices without a significant shift to substitutes").

253 See 2 M. Handuer, Twenty-Five Yeans of Antrtadst 1049-51 (1973).

254 Brown Shoe Co. v. United States, 370 U.S. 294, 325 (1962).

255 United States v. Grinnell Corp., 384 U.S. 563, 591 (1966) (Fortas, J., dissenting).

258 Give up? The left-hand column lists the markets that have been adopted. See Columbia Metal Culvert Co. v. Kaiser Alum. \& Chem. Corp., 579 F.2d 20, 25-30 (3d Cir.) (aluminum culvert pipe), cert. denied, 439 U.S. 876 (1978); United States v. Amsted Indus. Inc., 1974-2 Trade Cas. 175,208 (N.D. III. 1974) (cast iron pipe); United States v. Paramount Pictures, Inc., 334 U.S. 131, 172-73 (1948) (first-run feature films); United States v. Columbia Pictures 
Not surprisingly, the Commission's report does note the concern of several Commissioners that, "due to the sometimes narrow definition of relevant markets . . . , a no-conduct approach would unfairly dissolve firms that owned a dominant share of an insignificant market." 257 Reference to this so-called "dominant share" is contradictory and the concept contains two fundamental errors: the insignificant market is no market at all and the "dominant share" of such a market is an insignificant share of a market properly defined. Should such an approach to market definition be adopted, the no-fault concept could find application to countless firms. The Commission, however, washes its hands of the matter by urging that the appropriate congressional committees determine the proper definition of monopoly power to be applied in a non-conduct proceeding. ${ }^{258}$

One would think that the members of the Commission would have provided some guidance to the congressional committees as to the proper definition of monopoly power and that the Commission itself would have wrestled with the question whether there should be a standard for market definition under the new legislation different from that which currently applies in Clayton Act section 7 and Sherman Act section 2 proceedings. The present standards for market definition are hardly a model of clarity, and if the Commission could offer no solution, it seems disingenuous to drop the riddle into the lap of Congress as though it were a mere detail. Indeed, this is an area where a study commission could have made its greatest contribution, as there is no aspect of antitrust which is in greater need of clarification.

If the definition of monopoly power is less than clear, the definition of persistence is totally obscure. How many years must pass before a monopoly becomes "persistent"? Twenty? Ten? Five? Six months? What happens if the market share fluctuates sig-

Corp., 189 F. Supp. 153, 183-92 (S.D.N.Y. 1960) (feature films for television); United Fruit Co., 82 F.T.C. 53, 148-49 (1973) (bananas), modified, 85 F.T.C. 7 (1975); Yoder Bros. v. California-Florida Plant Corp., 537 F.2d 1347, 1366-68 (5th Cir. 1976) (chrysanthemums), cert. denied, 429 U.S. 1094 (1977); United States v. Corn Prods. Refining Co., 234 F. 964, 1003-04 (S.D.N.Y. 1916) (corn syrup), appeal dismissed, 249 U.S. 621 (1918); United States v. Chas. Pfizer \& Co., 246 F. Supp. 464, 467-70 (E.D.N.Y. 1965) (citric acid); United States v. Empire Gas Corp., 537 F.2d 296, 303-04 (8th Cir. 1976) (liquid petroleum gas), cert. denied, 429 U.S. 1122 (1977); United States v. General Dynamics Corp., 341 F. Supp. 534, 555-56 (N.D. III. 1972) (coal), aff'd on other grounds, 415 U.S. 486 (1974); United States v. Aluminum Co. of Am., 233 F. Supp. 718, 722-26 (E.D. Mo. 1964) (aluminum curtain wall), aff'd per curiam, 382 U.S. 12 (1965); United States v. National Steel Corp., 251 F. Supp. 693, 694-97 (S.D. Tex. 1965) (prefabricated metal buildings), cert. dismissed, 386 U.S. 1000 (1967).

257 Reporr, supra note 2 , at 172 n.36.

258 Id. 
nificantly over this period? What if it has begun falling? What consideration should be given to the entrance of aggressive new competitors? And if a patent has been expired for one year, has the monopoly persisted for one year or eighteen years? Inexplicably, "persistence," the centerpiece of the Commission's proposal, is left totally undefined.

With the definitions of both "monopoly power" and "persistence" so uncertain and perplexing, dissolutions could become the order of the day. But why, one might ask, should dominant power resulting from possession of an important trade secret or trademark be subject to dissipation through structural relief? What about the continued dominance of a company after its patent has expired? Or the success that comes in a growing market resulting from superior skills, superior product, natural advantages, or economic and technical efficiency? 259

The point is that the hallmark of good business strategy is to offer a product that is distinctive, that differs from those already on the market, and that enables the seller honestly to claim that his brand is superior. Moreover, it is to be expected that a competitor who makes it to the top will endeavor to remain there by continuing to compete vigorously, rather than deliberately to relinquish that position at the end of some appropriate period of time.260 Under the Commission's proposal, however, failure to step down could prove disastrous. To a prosecutor anxious to win a case, every product difference can be made the basis of market differentiation and any span of time can indicate "persistence." If we were to continue to gerrymander markets under no-fault legislation, and if the label of "persistence" were to be applied to virtually all but new entrants, we could be restructuring the entire American economy because hundreds, if not thousands, of companies would be vulnerable to governmental proceedings for structural relief.

259 See id. 392-93 (separate views of Commissioner Javits).

200 See California Computer Prods., Inc. v. IBM, 613 F.2d 727, 742 (9th Cir. 1979) (IBM "was entitled to maintain its ... dominant position in the market ... through 'business acumen" .... Where the opportunity exists to increase or protect market share profitably by offering equivalent or superior performance at a lower price, even a virtual monopolist may do so."); Telex Corp. v. IBM, 510 F.2d 894, 927 (10th Cir.) ("[T]echnical attainments [by a monopolist] were not intended to be inhibited or penalized by a construction of section 2 of the Sherman Act to prohibit the adoption of legal and ordinary marketing methods already used by others in the market, or to prohibit price changes which are within the 'reasonable' range, up or down."), cert. dismissed, 423 U.S. 802 (1975); Berkey Photo, Inc. v. Eastman Kodak Co., 457 F. Supp. 404 (S.D.N.Y. 1978) ("[A] monopolist is permitted, and indeed encouraged, by $\S 2$ to compete aggressively on the merits . "), modified, 603 F.2d 263, 281 (2d Cir. 1979), cert. denied, 100 S. Ct. 1061 (1980). 


\section{Rationales and Criticisms}

The Commission's Report, seeking to blunt expected opposition, states that it would be the rare case in which there is a finding of no-fault monopolization and that, normally, monopoly will persist only through indulgence in culpable conduct. ${ }^{261}$ This being so, why eliminate the requirement of proof of such culpability merely to reduce the burdens of prosecution? Is easing the task of the Department of Justice and the Federal Trade Commission a social value which transcends the importance of preserving the incentive for businesses to succeed? 202 Should we, for the sake of expediency, deprive the public of the benefits of enterprises that have achieved success through skill or superior production or methods, and that have served their suppliers, their customers, their employees and their communities well and are substantial providers of tax revenue to the government? It would be easier to dismember our major corporations by government fiat without any trial at all. Under the no-fault standard, the courts would no longer be courts but economic regulatory boards, passing not upon questions of law but upon the shape of the economy. It is unsettling to contemplate subjecting successful enterprises to major surgery merely because the Government would like to be spared the necessity of proving that their "persistent monopoly power" had been unlawfully acquired or maintained. ${ }^{263}$

It is appropriate to leave the subject of no-fault monopolization with the question that the Commission should have answered initially; namely, what are the economic and social gains and losses that would result in restructuring a company whose dominance has resulted from its own superiority? While the rationale for the no-conduct standard appears to be that the end justifies the means, the threshold question should have been whether that end is economically or socially desirable to begin with.

261 Report, supsa note 2 , at $155,157$.

262 In this connection it is interesting to note that after participation in negotiation of an international antitrust code for the United Nations Conference on Restrictive Business Practices, Joel Davidow of the Antitrust Division reportedly expressed satisfaction at the success United States negotiators had achieved in excluding "no conduct" violations based purely on corporate size and structure. See [1980] 961 anttrrust \& Trade Reg. Rep. (BNA) A-11.

263 There is considerable doubt as to whether litigation would actually be expedited by the Commission's proposal. See REPORT, supra note 2, at 358-62 (separate views of Commissioner Hatch), 393 (separate views of Commissioner Javits). 


\section{CoNCLUSION}

Both of the Commission's proposals represent a triumph of theory over fact. The report contains no empirical demonstration of any need for radical changes, nor any appraisal of the likely effects of such changes upon the economy. No facts are marshalled in support of the Commission's contentions or recommendations; no persuasive economic or social justifications are offered for its conclusions; and the legal documentation is sparse, highly selective and basically incorrect. While the Commission has seized upon a few isolated cases as examples of the supposed deficiencies in existing law or as supportive of its doctrinal changes, examination of the entire body of monopoly law reveals a decidedly different picture. The very least that can be expected of the proponents of any reform is that they not misdescribe the law they seek to revise and that they rely on facts, not rhetoric, in arguing the need for reform.

The proposal to adopt the no-conduct monopolization concept would magnify structure as the sole standard of illegality while ignoring conduct, or the lack thereof. In contrast, the recommendation to dilute or destroy the dangerous probability requirement in the law of attempted monopolization would elevate conduct as the primary criterion for assessing illegality to the virtual exclusion of structure. If the former standard has come to be referred to as "no-conduct," the latter can just as well be termed "no-structure." Neither approach is valid because the proper application of section 2, whether in monopolization or attempted monopolization cases, requires" evaluation of structure and conduct together, to reach just and economically desirable results. 